\title{
برنامج قائم على الأنشطة الفنية لتنمية بعض القيم الاقتصادية لطفل الروضة
}

$$
\begin{gathered}
\text { الباحثة / هناي أحمد فؤاد رمضان } \\
\text { باحثتماجستير } \\
\text { أشراف }
\end{gathered}
$$

د/ سماح رمضان مصطفى خميس

$$
\text { مدرس أصول تربيتش الطفل }
$$$$
\text { كليت رباض الأطفال - }
$$
جامعت المنصورة
أ.د/ أمسل محمد القــــلداح

أستاذ مناهج وبرامج الطفل

عميد كليت رياض الأطفال السابق ووكيل الكليت لشئون الدراسات العليا. كليت رياض الأطفال. جامعت المنصورة الاطفال

$$
\begin{aligned}
& \text { المجلت العلميت لكليتّرياض الأطفال - جامعت المنصورة } \\
& \text { المجلد الخامس ـ العدد الثالث }
\end{aligned}
$$

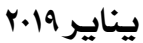




\section{برنامج قائم على الأنشطة الفنية لتنمية بعض القيم

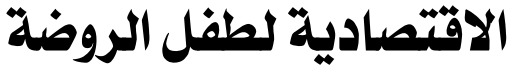

أ أ هناء أحمد فؤاد رمضان

تعد مرحله الطفولة ركيزة هامة فـي حيــاة الفـرد، ومــصير نمــوه في المستقبل كما تتقق أدبيات التربية وعلم النفس على أن السنوات الست الأولى

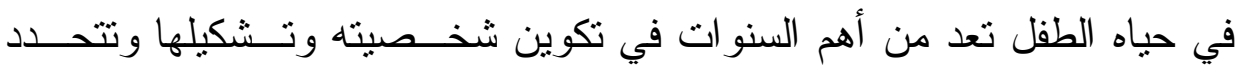

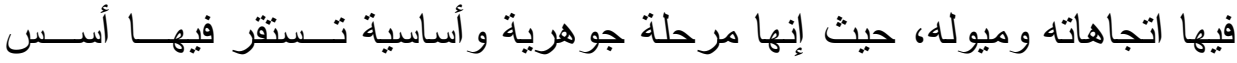
التزبية وتبنى عليها مر احل النمو التي تليها، فما يكتسبه مــن قـيم و اتجاهــات

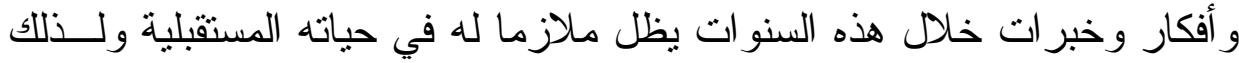

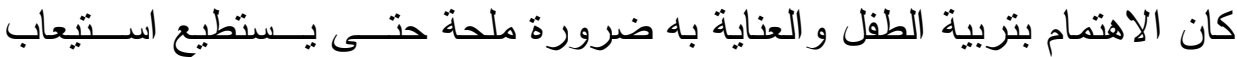

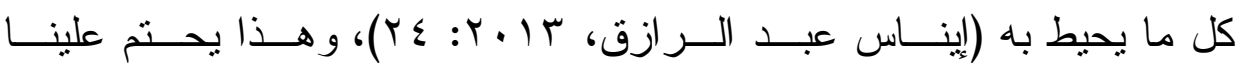

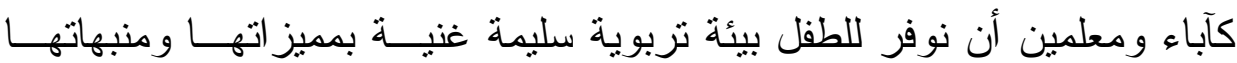

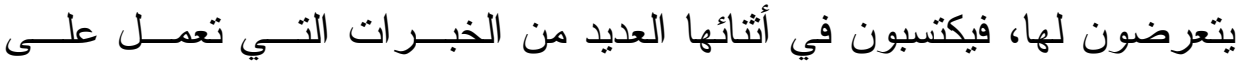

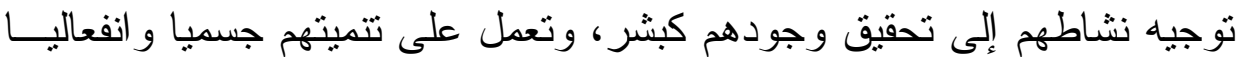
و عقليا واجتماعيا، ذللك لان فثل الطفل في حياته المستقبلية يرجع إلـى أســباب

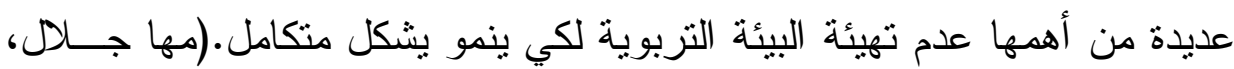
$(\leqslant 0: r \cdot 1 \leqslant$

\begin{tabular}{lll} 
& & \\
\hline * باحثتماجستير.
\end{tabular}




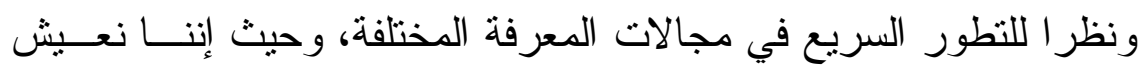

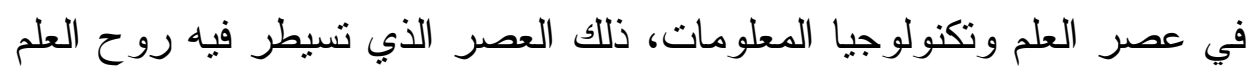

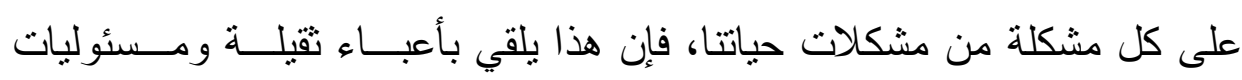

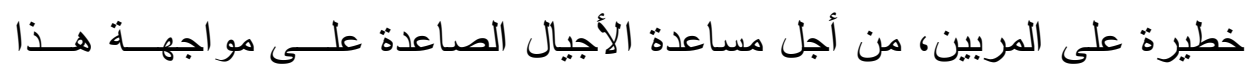
التطور العلمي، وأن يتجه التزبويون إلى استغلال مرحلة الروضة كمدخل للتعليم

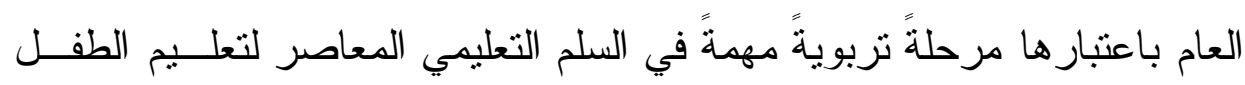
الكثير ، قبل التحاقه بالمرحلة الأولى حيث أصبحت الآن فكرة "برونر" القائلة بأن فئل

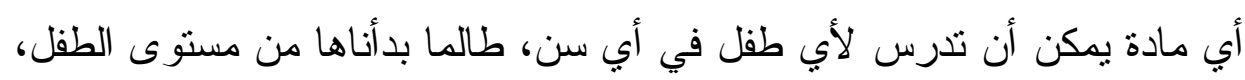

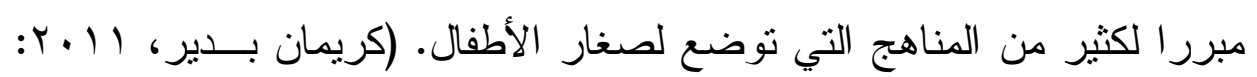

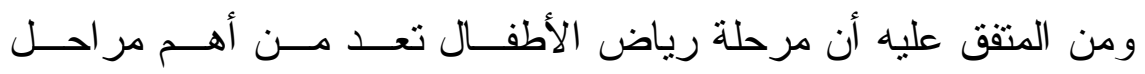

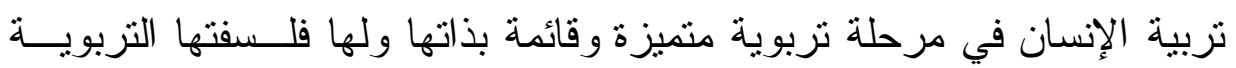

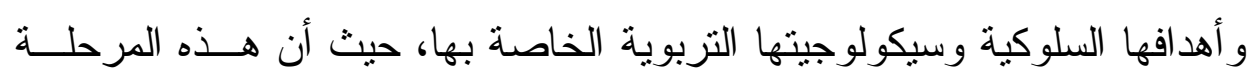

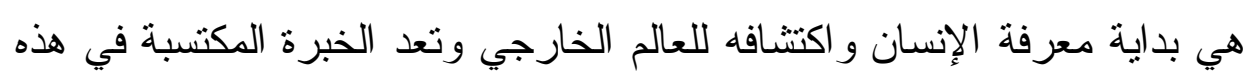

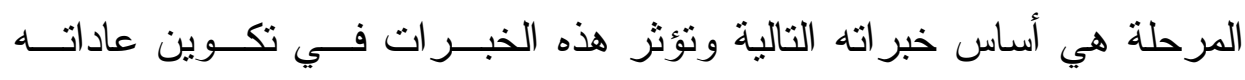

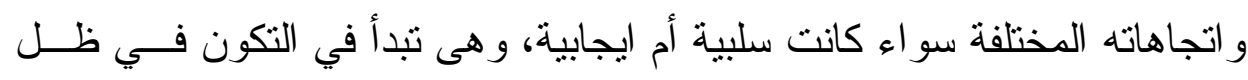

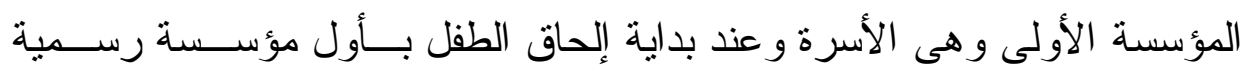

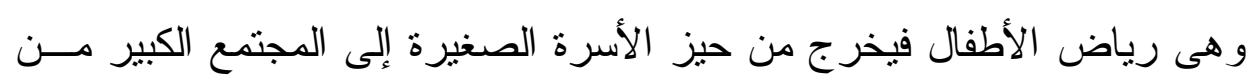

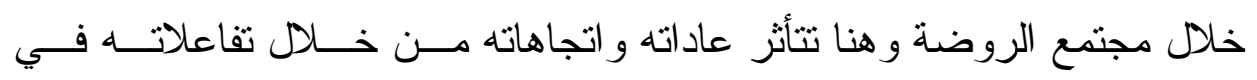

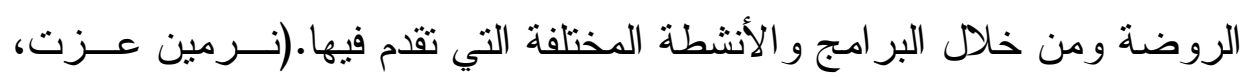

(I $\leqslant:$ Y I V 
و على هذا يجب الاهتمام بإعداد البر امج و الوحدات المختلفة التـي تهـتم

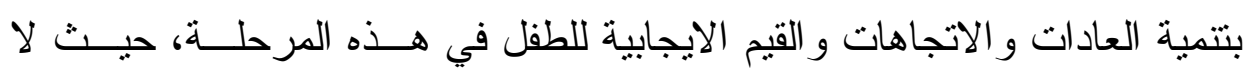
يمكن أن تقدم له العادات و الاتجاهات و القيم الايجابية بــشكل تلقينــي إرشــادي

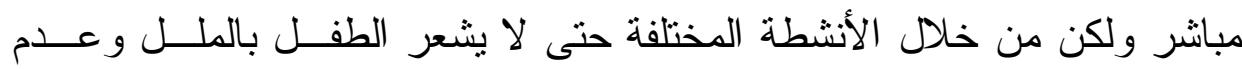

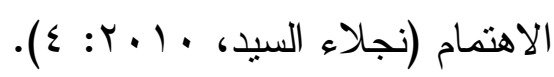

ومن هنا تأنى أهمية إعداد وحدات الأنشطة الفنية التي تعمل على تتميــة العادات و الاتجاهات و القيم الايجابية لدى طفل الروضة، حيث تعتبـــر الأنـشطة

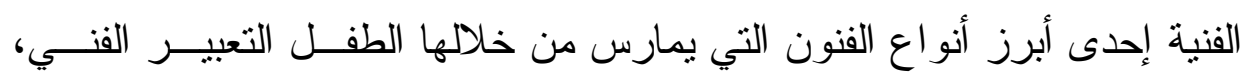

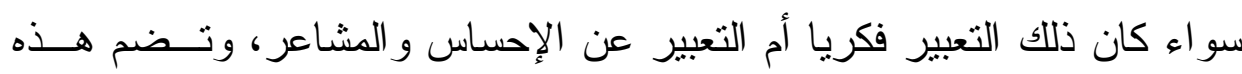
الأنشطة مجالات متعددة منها فن الرسم، فن التصميم، فن الكو لاج و غيرها مــن المجالات الفنية التي تساهم في بناء الفرد وتكوينه من الناحية الانفعالية و النفسية،

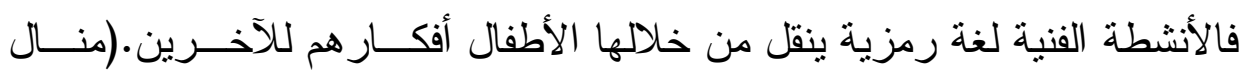

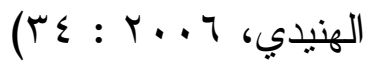

ومن الخطأ اعتبار الأنشطة الفنية التـي تُــدرس فـــي مدارســنا اليــوم

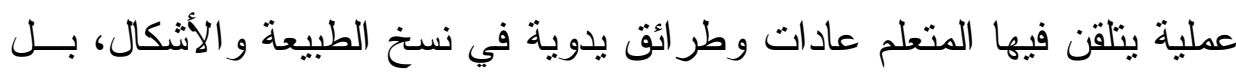
القصد هو أن يكتسب خصالا نفسية تتأصل في شخصيته وتصبح مــن طبائعسـه الأساسية، إذ أن هذه الخصال تتمو وتتطور مع المتعلم إذا أحيط بجو من الحرية و التقهم عن طريق ممارسة العمل الفني، بمعنى التربيـــة عــن طريــق الفــنـ،

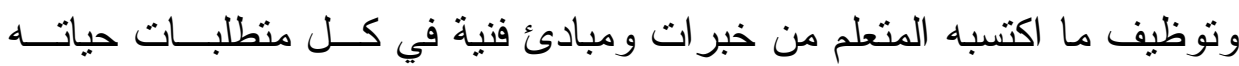

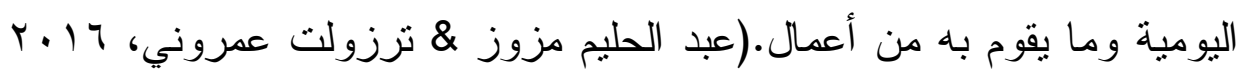
(O) : 
فالمعلم لا يُعلم الطفل الفن كفن، و الرسم كرسم، بقدر ما يعلمه الملاحظــــة

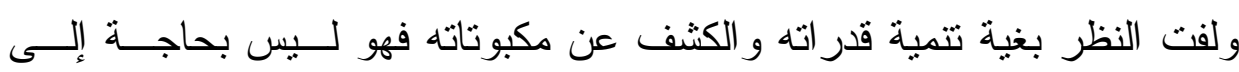

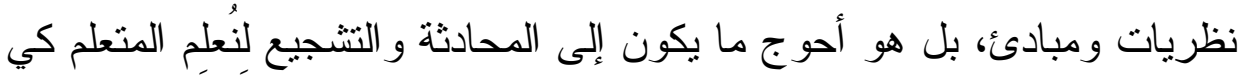

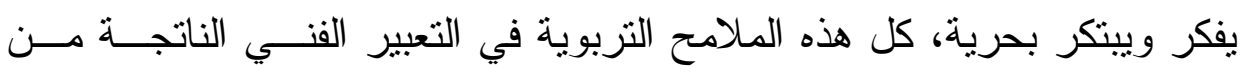
ممارسة الأنشطة الفنية المختلفة كان قد أوصى بهانها المجمع العالمي للتربية الفنبة

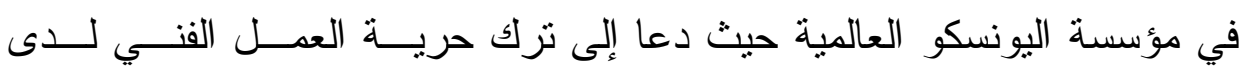

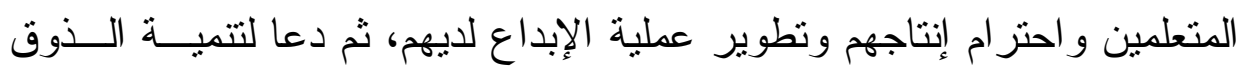

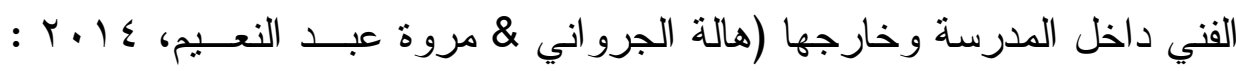

فعند إتاحة الأنثطة الفنية للطفل، سرعان ما ينخرط فيها، وبذللك تتاح لـهـ

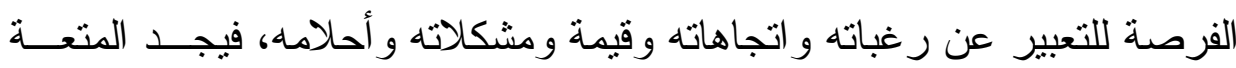
التي تدفعه إلى مزيد من التعبير عن ذاته، ومن ثم فالأنشطة الفنية يمكن أن تشهر

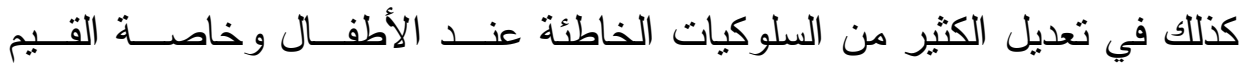

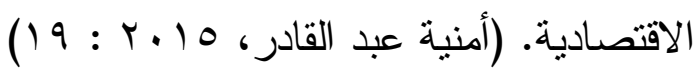

حيث تعتبر القيم الاقتصادية واحدة من أهم تصنيفات القيم بوجسه عـام،

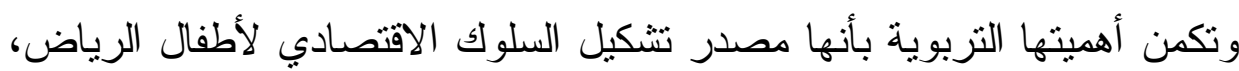

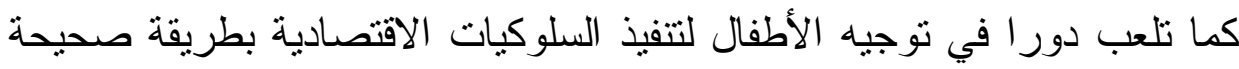

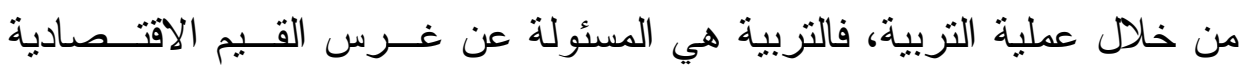

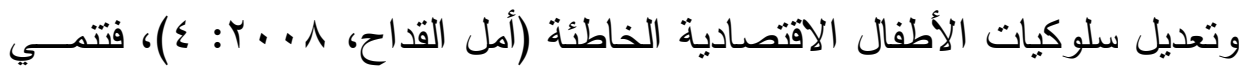
كذلك لاى الطفل مختلف جو انب شخصيته بالعلوم و المعارف التي تربيه تربيــة

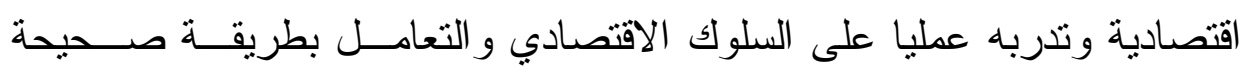


اقتصاديا كالمحافظة على الممتلكات العامة و الخاصــة، وترشـــيد الاســتهلاكك، ومساعدة الآخرين، و إكسابه خبرات عملية البيع و الثر اء، و التعامل مع الآخرين في الثؤون الاقتصادية، وحب العمل و الإنتاج، وتحمل المسئولية، و احتر ام كـلـل عامل وتقدير قيمة عمله، لكي يتمكن الطفل من مسايرة التغيـر ات الاقتــصادية بالبيئة المحيطة به.(خلف احمد، IV r Y Y Y I )

الأمر الذي يفرض ضرورة الاهتمام بغرس بذور القيم الاقتصادية لــدى الطفل منذ صغره عن طريق ممارسة الأنشطة المختلفة، فهي لا تقل أهمية عـنـ المعارف التي يزود بها، ولذا فمن الأهمية بمكان تتمية هذه القيم لديه لأن ذلـــك سيرشده إلى كيفية التصرف السليم المقتصد و التعامل مع الأشياء بطريقة موجهة

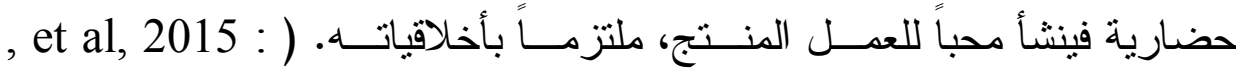

(Ann Farrell622

فطفل الروضة يتأثز بمعلمه فهي قدوة له و عنصر هام في عالمه، كما أنه

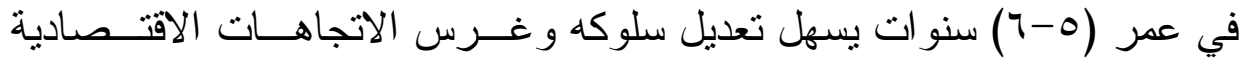
الأولية الايجابية لديه عن طريق الأنشطة الفنية، فهذا السن يمنل مرحلة الروضة

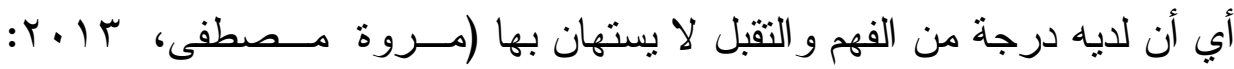
ج (ب)، وفي الوقت نفسه يشكل مرحلة تمهيدية لأولى مر احل التعليم النظاميـــة،

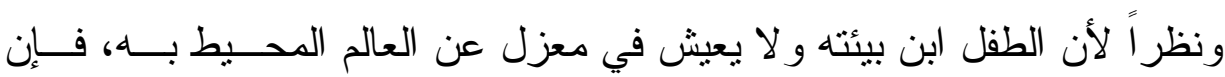

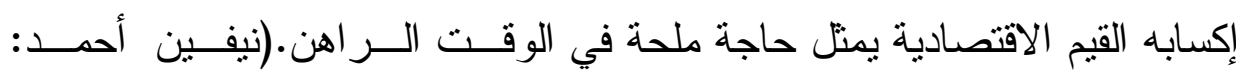




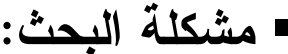

تعتبر تتمية الاتجاهات و العادات و القيم الأخلاقية و الــسلوكية الإيجابيــة

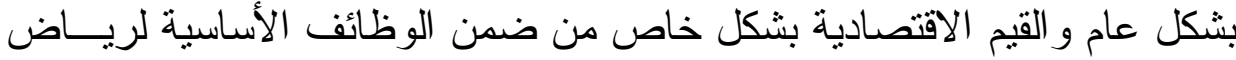

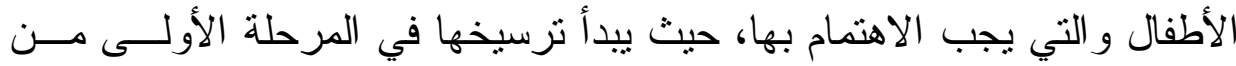

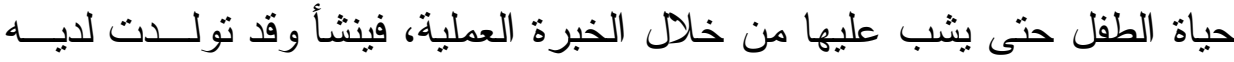

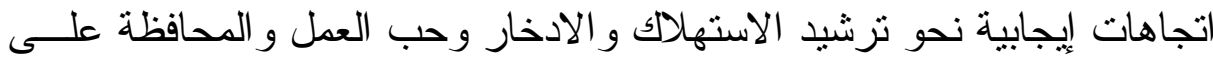

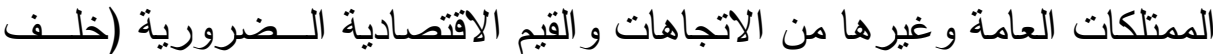

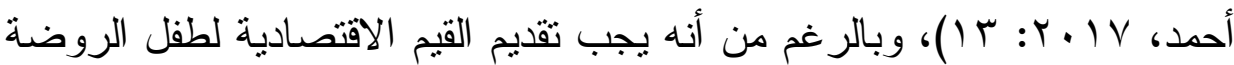

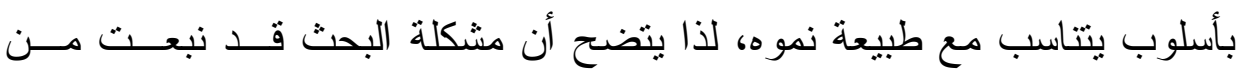

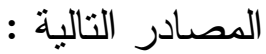

-من خلال الإطلاع على العديد من الدراسات السابقة التي تتاولت تتمية القيم

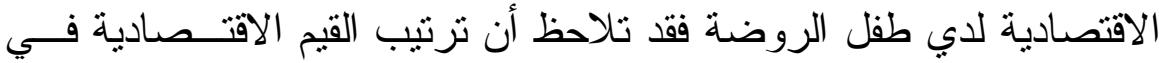

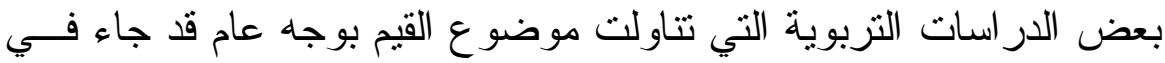

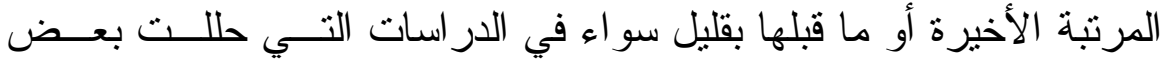

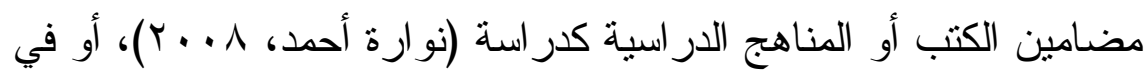

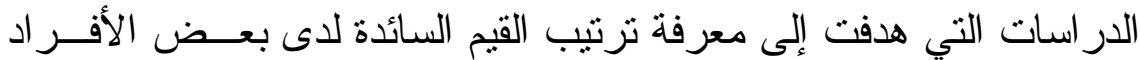

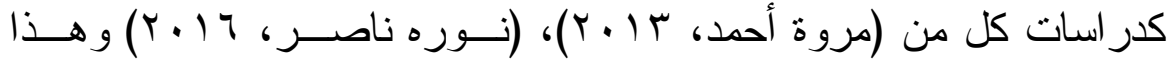

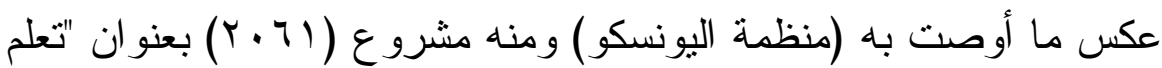

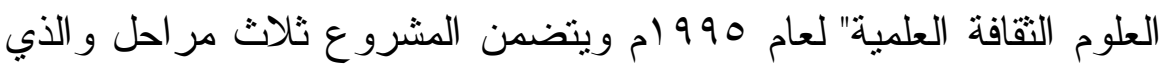

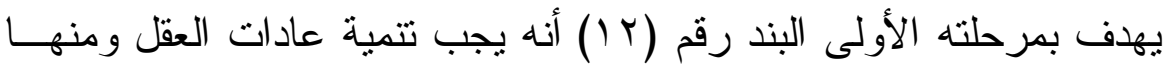

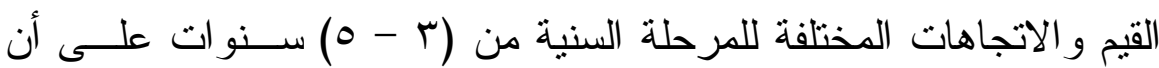


يكون مدعما بالأنشطة المناسبة وبخبر ات التعلم المفتوح مر اعيــا أسـاليب النمو ("). (unesco, 2018)

- من خلال عمل الباحثة في بعض الروضات تلاحظ لها الاعتماد الكلي على تلى

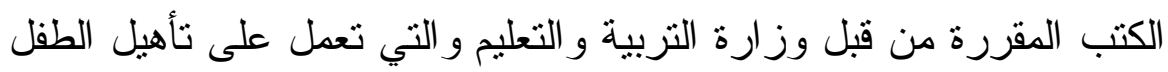

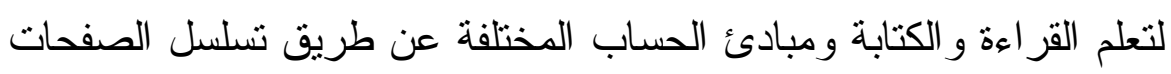

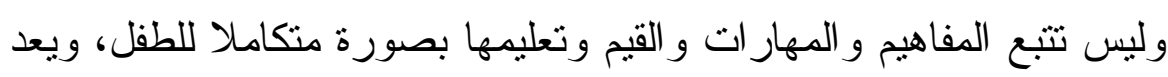

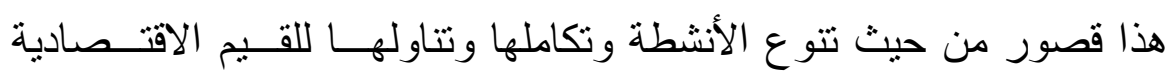

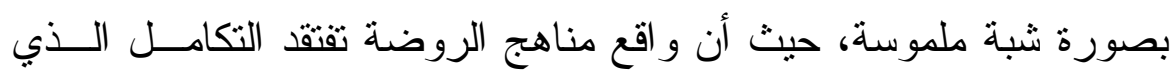

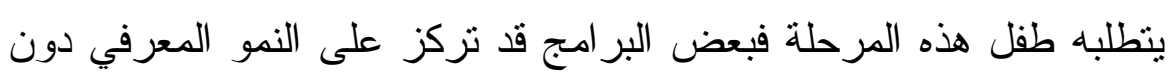

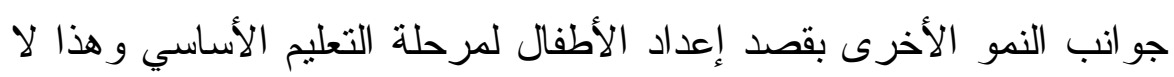

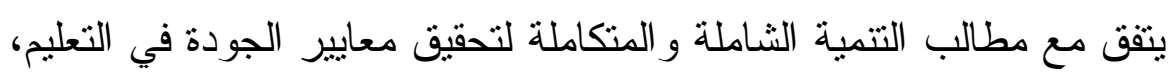
وكذلك يتتافى مع أبحاث بياجية التي توضح أن الأطفال من سن سنتين إلى لى لئل سن سبع سنو ات يخضعو المرحلة ما قبل العمليات.

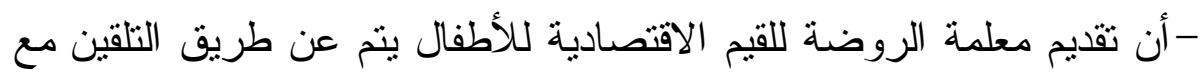

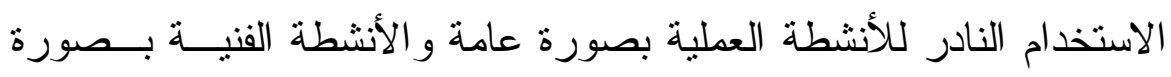
خاصة، ففي الغالب لا تتذخل المعلمة في ممارسات الأطفال للأنشطة و التي لأني

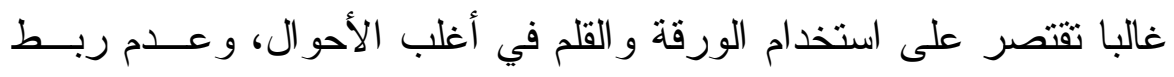

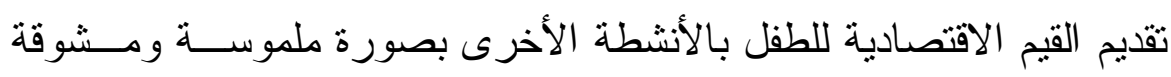

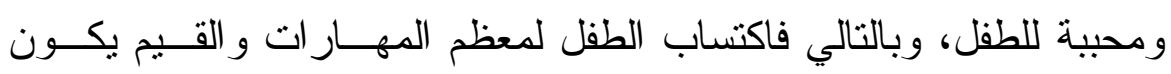
محاطا بالكثير من الأخطاء.

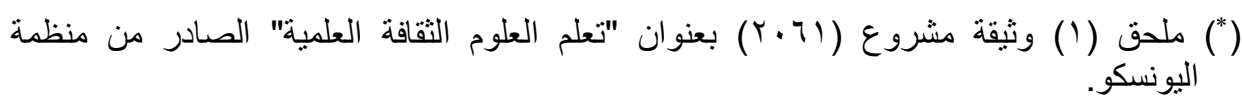


ومن هنا تتحدد مشكلة البحث الحالي في تــدني وضــــف تقــديم القــيم

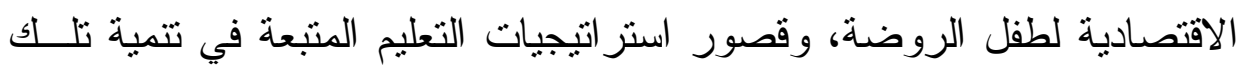
القيم مما أدي إلى وجود اتجاهات سلبية نحو تعلم طفل الروضة هذه القيم. ومن هذا المنطلق أصبحت هناك حاجة ضرورية إلي تــصميم برنــامج

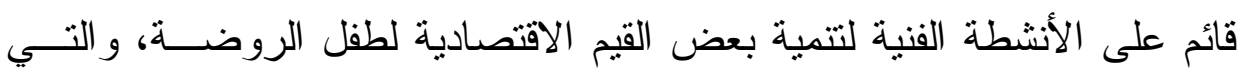
يكتسب الطفل من خلالها خبرة عملية تؤهله للتفاعل الاجتماعي، وهذا ما يحاول

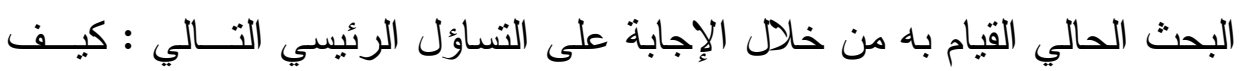

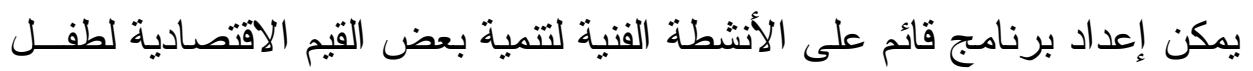
الروضة

\section{ويتفرع من هذا السؤال التساؤلات الفرعية التالية :}

ا ـ ما القيم الاقتصادية المناسب تتميتها لدي طفل الروضة ؟

r. ما أهمية القيم الاقتصادية التي يمكن تتميتها لدي طفل الروضة؟ r. ما البرنامج القائم على الأنشطة الفنبية لتتمية بعض القيم الاقتصادية لدي طفل الروضة ؟ مادج ع. ما فاعلية البرنامج القائم على الأنـشطة الفنيــة لتتميــة بعــض القـيم الاقتصادية لدي طفل الروضة؟ لماءع

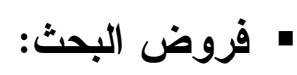
أمكن صباغة الفروض على النحو التالي : ا- توجد فروق ذو دلالة إحصائية عند مستوى دلالة 0 . , · بــين متوسـطى

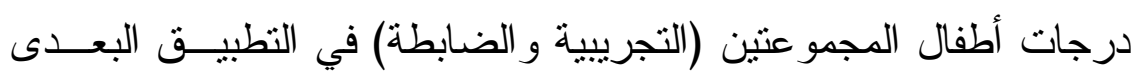
لمقياس القيم الاقتصادية لصالح المجموعة التجريبية. 
r- توجد فروق ذو دلالة إحصائية عند مسستوى (0 . • ) بـين منتوسـطي

درجات أطفال المجموعة التجريبية فـي التطبيةـين (القبلــي و البعـدى)

لمقياس القيم الاقتصادية لصالح التطبيق البعدى.

\section{ه أهداف البحث:}

هدف البحث الحالي إلى التعرف على "برنامج قائم على الأشطة القتية

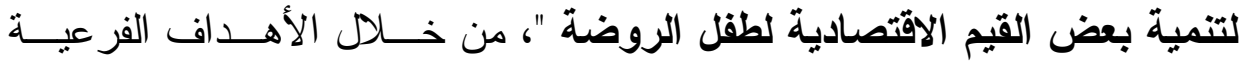

- - تحديد القيم الاقتصادية المناسبةً لطفل الروضة.

- - إعداد مقياس للقيم الاقتصادية اللازمة لطفل الروضة.

- إعداد برنامج قائم على الأنشطة الفنية لتتمية بعض القـيم الاقتــصادية

لطفل الروضة.

- تحديد فاعلية البرنامج القائم على الأنشطة الفنية لتتمية القيم الاقتــصادية

$$
\text { ه أهمية البحث: الروضة. }
$$

تكمن أهمية البحث في ضرورة وحيوية الموضوع الذي يتتاوله، وهــو

التعرف علي برنامج قائم على الأنشطة الفنية لتتمية بعض القيم الاقتصادية لطفل

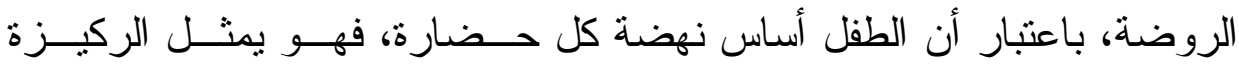
الأساسية للمجتمع الذي ينشأ بداخله، بالإضافة للدور الذي تلعبه الأنشطة الفنيــة كأداة فعالة في تزسيخ وتدعيم العديد من القيم الإيجابية ونبذ القيم السلبية بطريقة

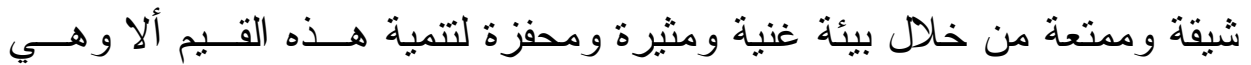


الأنشطة الفنية حتى يكتسب الطفل خبر ات اقتصادية متتوعة تساعده في التغلــبـ

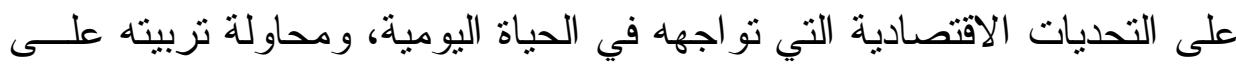

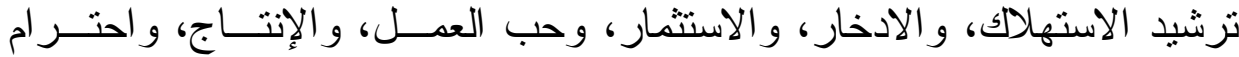

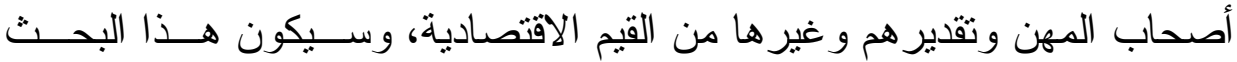
بمثابة إضافة علمية للمكتبة العربية.

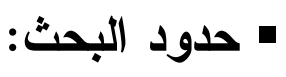

اقتصر البحث الحالي على الحدود التالية :

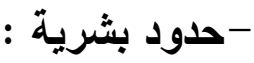

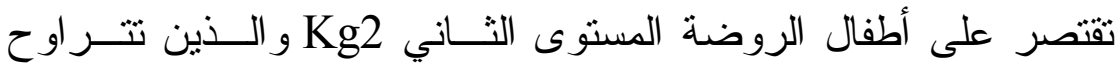

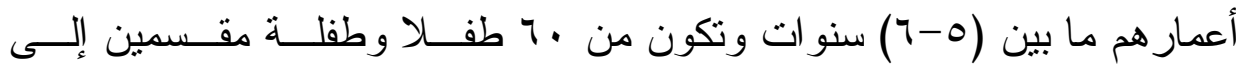

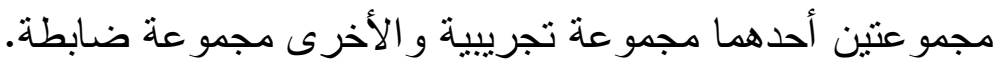

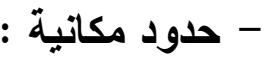

تقتصر على روضتي الحرية، وجزيرة الورد الابتدائية بمدينة المنصورة

و التابعة لإدارة شرق المنصورة التعليمية بمحافظة الدقهلية.

$$
\text { - حدود موضوعية : }
$$

اقتصر البحث الحالي على القيم الاقتصادية التالية : (ترشيد الاستهلاكى،

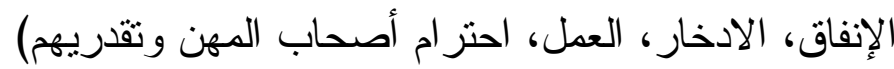

$$
\text { - حدود زمنية : }
$$

تم تطبيق التجربة الميدانية للبحــث الحــالي بالفـصل الدراسـي الأول 


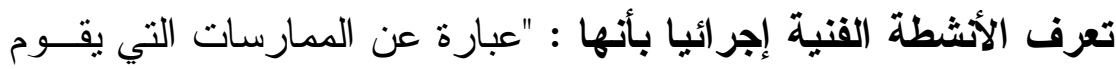

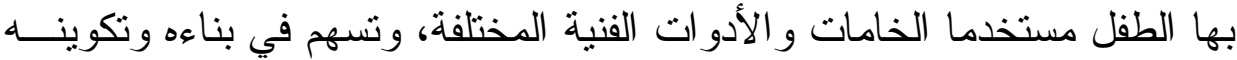

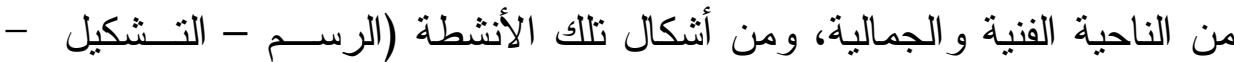

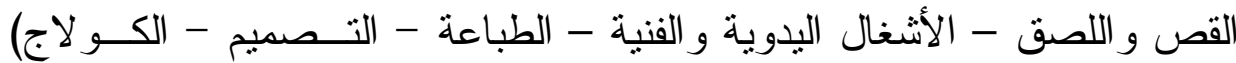

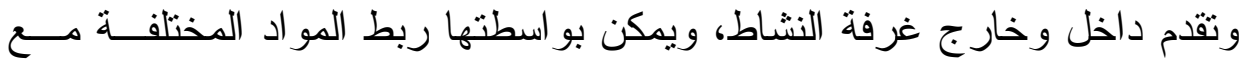
بعضها البعض في صورة وحدة متكاملة فيما يتعلق بدر اسة موضو ع معين، مما يؤدي إلى إحداث تو افق ايجابي في مظاهر ســلوك طفــل الروضــــة الجـسمية و الوجدانية و العقلية. - - القيم الاقتصادية لرياض الأطفال : تعرف القيم الاقتصادية إجرائيا بأنها : "اهتمام الطفل وميله إلى ما هو

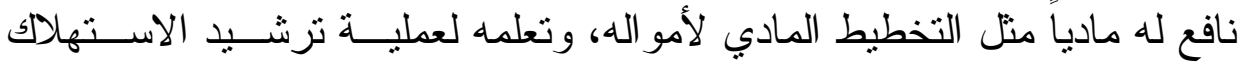

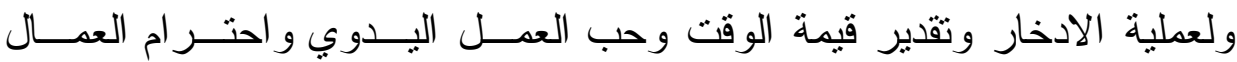

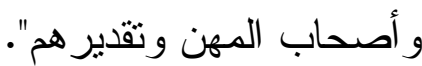

الإطار النظري و الدراسات السابقة : ينقسم الإطار النظري للبحث إلى محورين :

المحور الأول : الأشطة الفنية لطقل الروضة : يعتبر الفن مهما اختلفت أساليبه آو طر ائقه ما هو إلا وسيله مسن وســئل

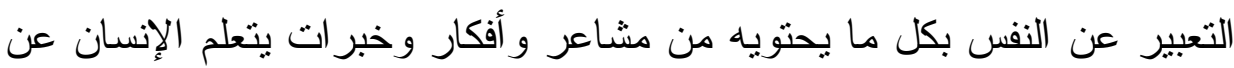


طريقها الكثير من المعارف و المعلومات التي تكتسب عن طريق تفاعـلـل الطفــلـ

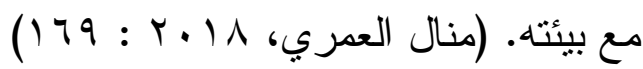

كما يعد الفن وسيله تربوية فعاله تساعد على النمو النفسي و العقلي للطفل، لقدرته على مخاطبة تفكير الطفل و إحساسه، فالفن بأنسشطة المختلفــة يسـساعد

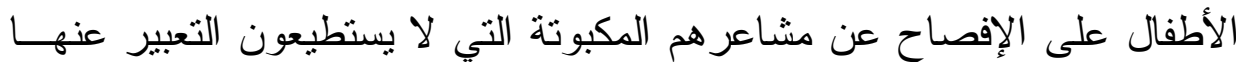

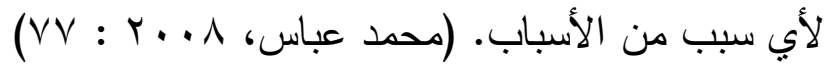

وتعد الأنشطة الفنية ركن من أركان النزبية الحديثة وتمثل مع الأنسشطة

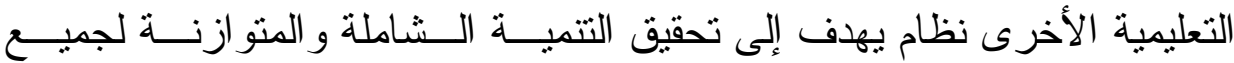

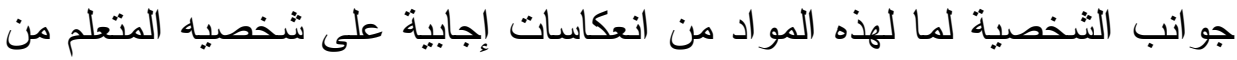

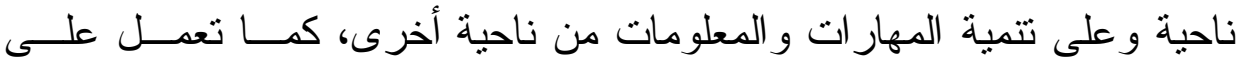
النهوض بالعملية التعليمية من خلال تتمية الطفل كعضو في المجتمع، إذ تعدـل على توسيع نقافته وتتمية القدر ات الإبداعية على التعبير، فهي تسعى إلـى بنـــاء فرد متكامل متو ازن مع نفسه ومتفاعل مع محيطه البيئي و الاجتمــاعي. (غـــادة

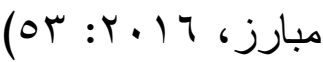
فالنشاط الفني هو أي نثاط يقوم به الطفل مـستخدما الخامــات و الأدوات

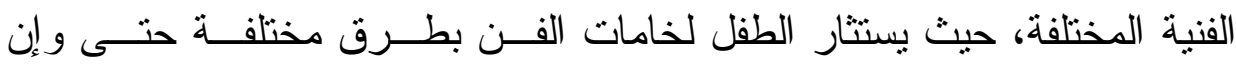
قصد اللعب بها وتجريبها و التعرف عليها مما يؤدي إلى صقل معرفـــه وتقـــيم خبرة جديدة تجتذبه وتزووده بمعلومات أكثر عن الأثنياء التــي يتعامـلـل معهــا، فيصبح ندريجيا قادر على التمييز بين الأثياء والخامات المختلفة و الابتكار بهـا،

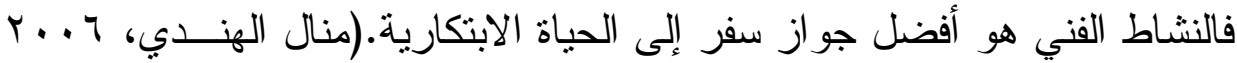


ويثير (182 : Curtis, D, 2011 أن ممارسه الطفل الأنـشطة الفنيــة

تشبع حاجاته ودو افعه للتعلم، فمن خلالها يــستطيع طفـلـل الروضـــة أن يحقــق الحركة و النشاط، ويحقق غايته من الاكتشاف من خــلال الخامــات و الأدوات، ويحقق حب الاستطلاع، ويحقق النجاح، ويعبر عن ذاته، ويحقق التعـاون مــن خلال ممارسة الأنشطة الفنية مع الرفاق. وتعد الأنشطة الفنية إحدى الوسائل المستخدمة للتعبير عـن الــفس مــن خلال الأعمال الفنية و المشـاركة و التعامل و المثابرة و إنهـــاء العهــلـ و الإنجـــاز و الثعور بالسعادة و الفخر و الاعتز از بالنفس، حين إنجاز العمل، مما يزيـــــــن ثقتة بنفسه وبقدر اته بامكانياتة خصوصا عند رؤية عمله و عرضه على الآخرين،

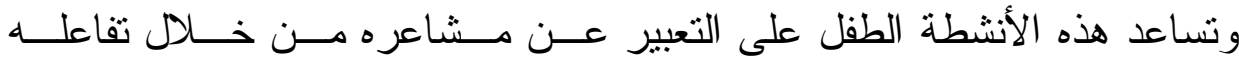
مع الخامات و الأدو ات و اكتثاف الألوان المختلفة ودرجاتهـــا و التمييــز بينهـــا، وتعلمة طريقه مزجها وما ينتج عنها من ألوان جديدة والتعرف إلى صفة الخامة و مميز اتها، و التجريب باستخدام خامات مختلفة.(نجلاء عفيفي، 1 ( ـ ب: r • ( ) وقد أثنارت (سهام عبد الهادي، Y. V V : 90) أن الأنشطة الفنبــة تعــد انعكاسات تتبع من الوجدان، و التذوق الجمالي، و الاحساس الفني، للطفل و أدو اتها هي : الرسم و التلوين و الطباعة و الموسيقى و الصلصسال و الخرز، و الهدف منهـــا

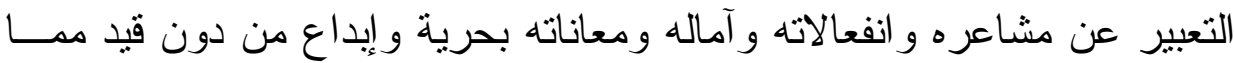
يساعد على تحرير شخصيته، وتحقيق ذاته وكيانه الإنساني، و اكتــساب القــدرة على الاتصال بالآخرين، كما تعد وسيلة للتعبير عن المتعة الناتجة عـن شــعور الأطفال بالإنجاز الذي يمنحة الثعور بالثقة بالنفس، وهي وسيلة للتعـرف إلــي اهتمامات الأطفال ومو اهبهم. 
وتساهم الانشطة الفنية في تتميه شخصيه المتعلم عن طريق إتاحة فرص

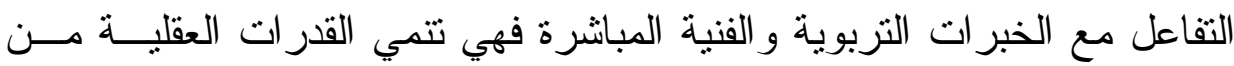

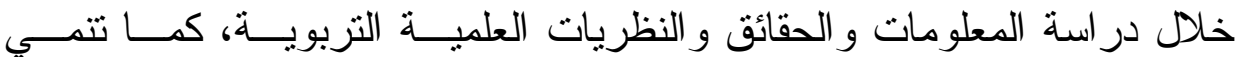

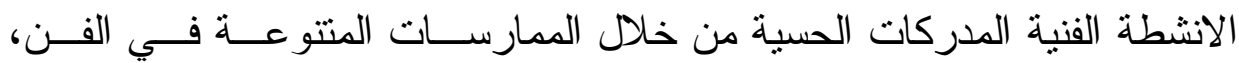
و إكسابه المهار ات التقنية التي تعينه على التحكم في استخدام الخامــات البيأيــة

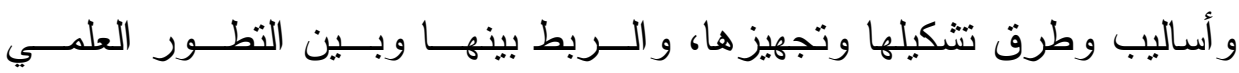
و التكنولوجيا المعاصرة، كما تساعد أيضـا على تتميه الجوانــبـ الوجدانيــة مــن خلال تكوين الاتجاهات الإيجابية للقيم الإجتماعية و الفنية.(محمد وهبة، 10 . ب :

وللأنشطة الفنبة دور مهما في بناء شخصية الطفل، فالنشاط الفني يسساعد الفرد على التعامل مع من حوله، ويزيد من شعوره بالرضا عن نفسه وتثته فيها

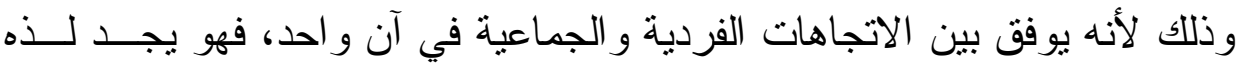

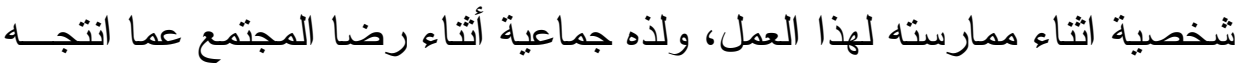

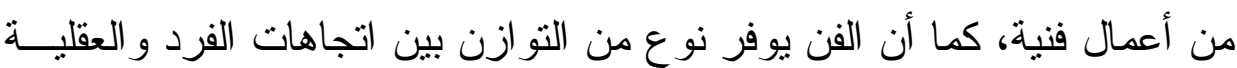
و الانفعالية و الفكرية و الحسية وبين الوعي و اللاوعي، حيث تعتبر الأنشطة الفنية

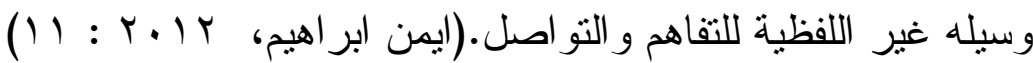
و الأنشطة الفنية بشكل عام هي كل ما يساهم في بناء الفرد وتكوينه مـن

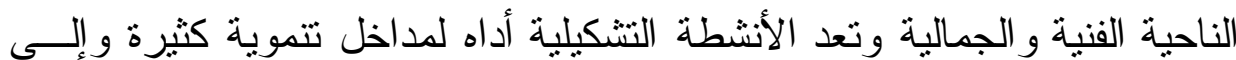
العلاج بالفن.(Koster \& Joan, 2012 : 71)

وتحقق الأنشطة الفنية ذلك عن طريق التثاعيات الحرة، فيحتاج للـشخص

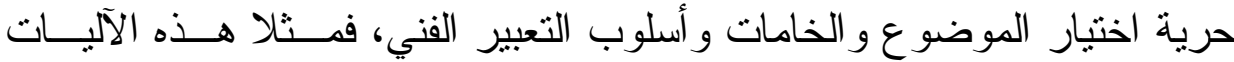


تساعد على إخر اج التخيلات و المشاعر الكبوثة داخله وتحويلها إلى تعبيرات فنيه

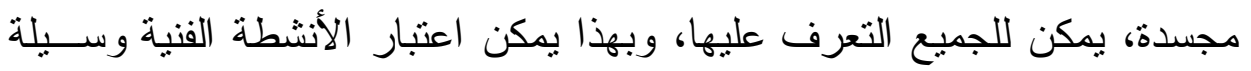

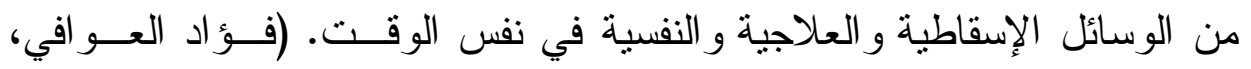

وتعد الأنشطة الفنية الوسيلة التربوية التي نصل بها إلى نفــوس أطفالنــا،

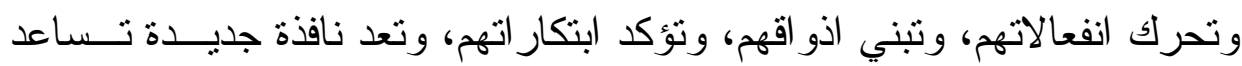

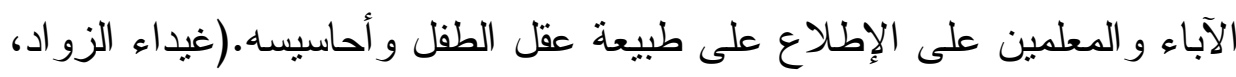
( $) \leqslant r: r \cdot 11$

ويري (29 : Bertling, 2005 أن مجال الأنشطة الفنية يمتــاز بتعـدد الخامات مما يتيح للطفل حرية توليف، ومعالجة هذه الخامات في إنتـاج أعمــال

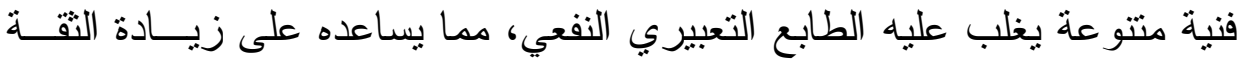

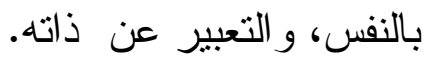

\section{- ت تعريف الأشطة الفنية :}

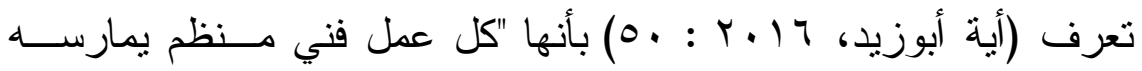

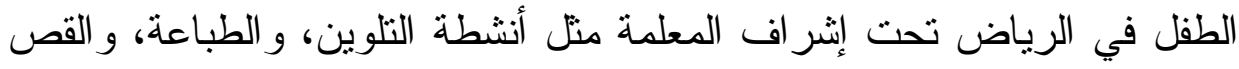
و اللصق، وعمل النماذج، و التتكيل، وهو كل فعالية فنيه يبذلها الطفل في سـبيل التعلم أو النمو.

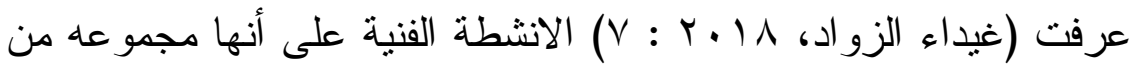

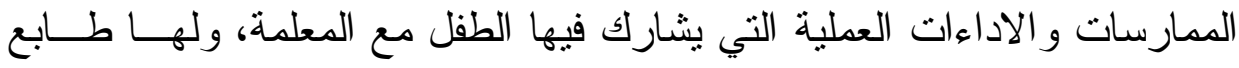

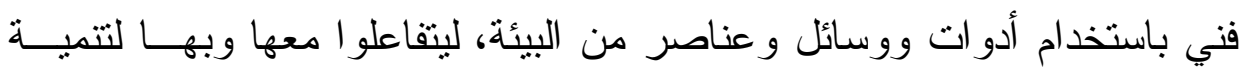

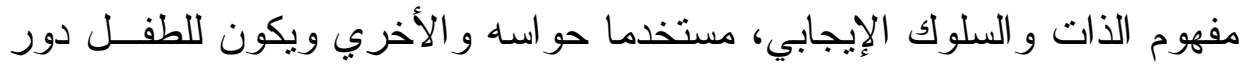


محوري وأساسي في أداء النشاط، ويقصد بهــا الاثــغال اليدويــة والأغــاني

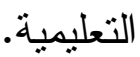

\section{وتعرف الأنشطة الفنية إجر ائيا بأنها : "عبارة عن الممارسات التي يقـوم}

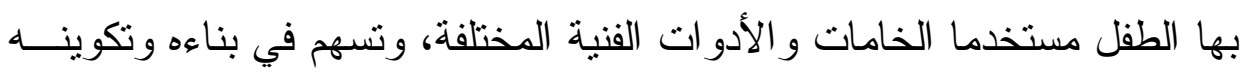

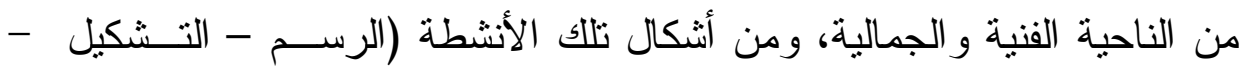

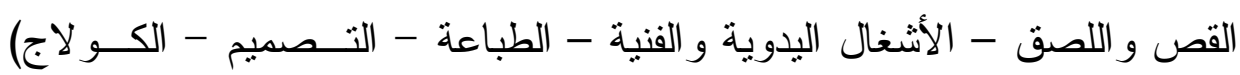

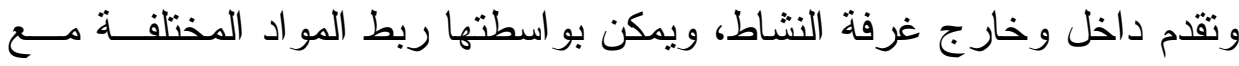
بعضها البعض في صورة وحدة متكاملة فيما يتعلق بدر اسة موضو ع معين، مما

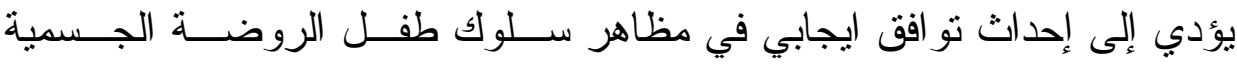

$$
\text { و الوجدانية و العقلية. }
$$

\section{• أهمية الأشطة الفنية لطفل الروضة :}

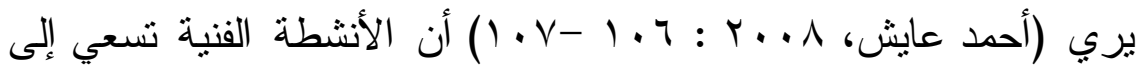
تحقيق جملة من الجو انب التي تتعلق بالمتعلمن، و التي تتمنل في تتميــهـ قــدرات

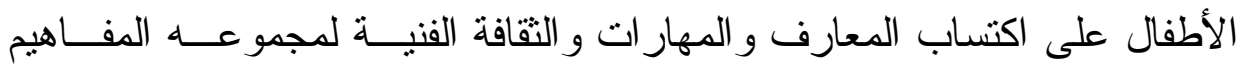
و المصطلحات الفنية، وفهها لمساعدتهم في كثف الحقائق، وتتمية قدر اتهم على التى

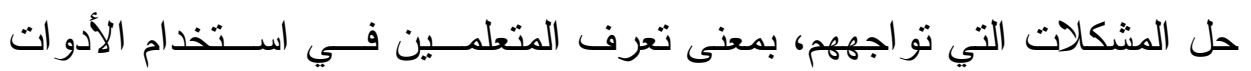

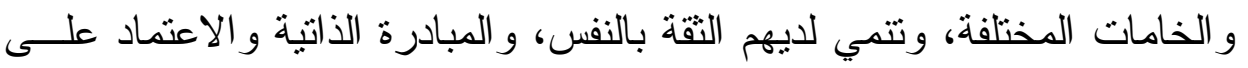

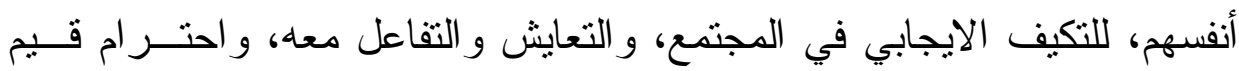

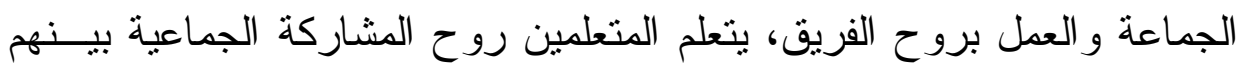
و التفاعل الايجابي في الصف الواحد. 


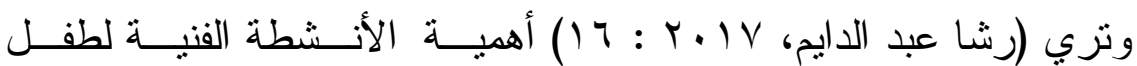

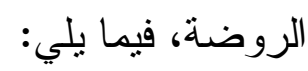

- إكساب الطفل المهارات اليدوية التي تتطلبها الحياة اليومية. - ممارسه فلك ودمج الصور ، وجمع الصور، وقصهان ولصقها. - أهمية تتميه قدره الطفل على استخدام بعض الأدوات البـسيطة كالفرشــاة و الورق و الأسفنج و الألو ان و غير ها من الخدمات. - الرسم الحر فيرسم ما يشعر به وما يحيط به من ظو اهر.

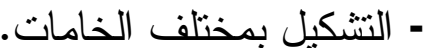

كما يضيف (163 : Melissa Menzer, 2015 أن الأنشطة الفنية تعـــ (وسيله علاجيه، وسيله تتخيصية، وسيله إسقاطيه، وتشاعد في بنــاء شخــصيه الطفل، وتساعد على التفاعل الاجتماعي، وتساعد على تتمية الاتجاهات و الميول و القيم).

\section{• أهداف الأشطة الفنية لطفل الروضة :}

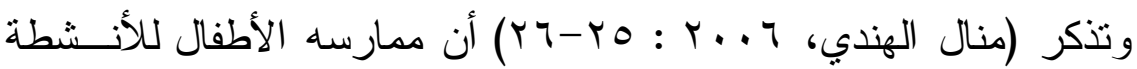

$$
\text { الفنية في الروضة تحقق الأهداف الأثية : }
$$

- التعبير عن أحاسيسهم ومشاعر هم بلغة تثكيلية حـرة باسـتخدام الأدوات،

$$
\text { و الخامات التي تتناسب مع مؤهلاتهم. }
$$

- تتميه قدر اتهم الإبداعية حيث بعتمد على أنفـسهم فــي مزاولــة الكــشف

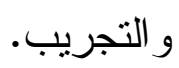




$$
\text { - الكثف عن قدر اته العقلية، ومهار اته الفكرية و اليدوية. }
$$

- اكسابهم عادات سلوكية سليمة، كالمحافظة علـى الأدوات الفنبــة وحسـسن

$$
\text { صيانتها. }
$$

- تعزيز مو اقفهم السلوكية : روح المبادرة، حب الإطلاع و القدرة على النقـــ و التحليل، وحب الآخرين، وقدرتهم على التعامل معهم، وحب العمل. - تتميه قدر اتهم على التخيل.

- تتميه قدر اتهم الخاصة بالسيطرة علي عـضلات اليـدين وتــدريبها علـى

$$
\text { استخدام الأدوات و الخامات الفنية. }
$$

- مساعده بعضهم على التخلص من بعض التوتز النفسي بالتعبير الحر. - تفهم نفسياتهم خلال عملهم، و إنتاجهم الفني.

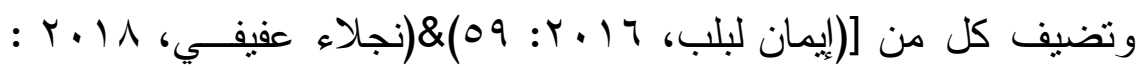

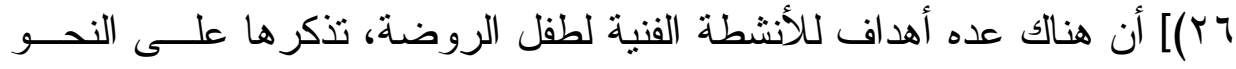

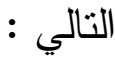

- إتاحة الفرصة للطفل لتأكيد ذاته، حيث تعمل الأنشطة الفنبة كمدخل متميـز ، لتحقيق الجانب التطبيقي و التقة من خلال الإنتاج الفني و اكتساب الخبــرات المربية للطفل و الإحساس.

- يحقق النشاط الفني نموا في شخصية الطفل، وزيادة في الاتـز ان النفـسي و التقة لما تفجره الممارسة الفنية من طاقــات ابتكاريـــهـ كمتــفس للــدو افع وتفريغ التوتز ات، و إعاده التوازن النفسي، كذلك إتاحة الفرصة للطفل لتأكيد

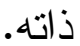


- حسن استخدام الطفل لحواسة المختلفة.

- تتمي الناحية العاطفية و الوجدانية.

- ملئ أوقات الفر اغ بشكل مثثر ونافع.

- تتميه المهار ات التقنية و اليدوية لطفل الروضة.

- تأكيد الذات و الثعور به.

- التفيس عن الانفعالات.

ـ أنواع الأنشطة الفنية :

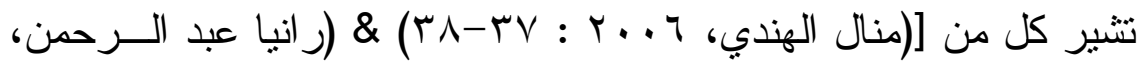

10

يأتي عرض أكثر ها استخدام من الأطفال :

ا- الرسم : هي اللغة التي يتو اصل بها الطفل مع الآخرين حيثما لا يسنطيع

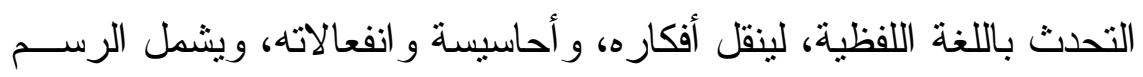

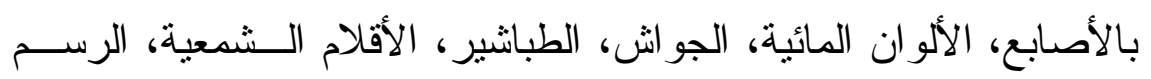

على الرمال، حيث أن الطفل يستطيع من خلال الرسم التعبير عن ذاتــه، التهاه

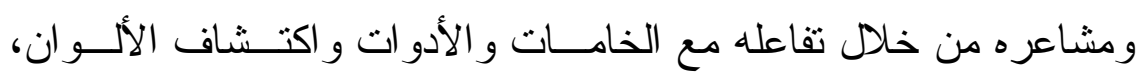

وزيادة على ذلك ان الرسم يساعده على تحقيق الاتز ان النفسي من خـــله

تتفيس الطفل عن المكنونات السلبية واستبدال الدو افع الــسلبية بالــدو افع

ايجابية، ويستتد تقديم الطفل في الرسم إلي عاملين مهمــين هــــا : الأول

يتعلق بتكوين علاقات مختلفة مع الأشياء، و الثاني يتعلق بقدره الطفل على ولى

ربط الأشياء ببعضها البعض من الناحية المكانية. 
r- التلوين : يعد من الانشطة الفنبـــة الأخـرى المحبـــة لــدى الأطفــال

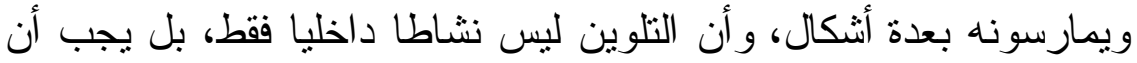
يمتد إلي خارج غرفه النشاط من خلال توفير منطقة في الحديقـة تفـسح

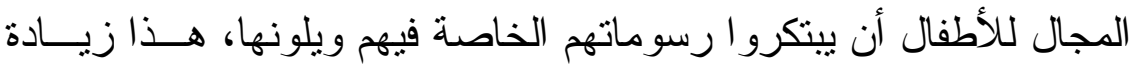

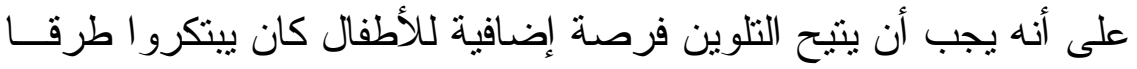
مختلفة لاستخدام الألوان مثل : (تلوين الفقاعات، نثر اللون لعمل أثتـكال

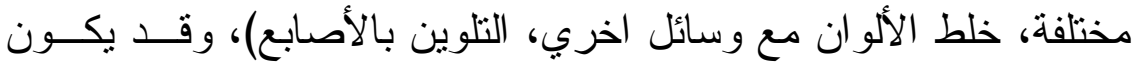

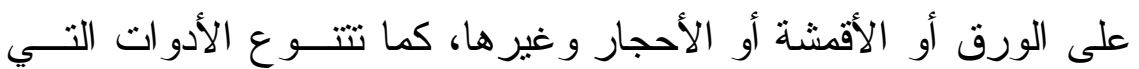
يستخدمها الطفل في التلوين.

r- القص واللصق : إن الأطفال يستغرقون وقتا طويلا لكي يسيطرو ا علـى المهار ات المطلوبة منهم في القص و اللصق و عادة يستمتعون أكثر عندما يتعرفون على خامات متتوعة ويبتكرون أنماط مختلفة من الصور مثـل : (استخدام أور اق القص و اللصق الملونة في تكوين أنشكال ونماذج مختلفة، استخدام خامات طبيعية وصناعية كالصدف، و الزهور و وغير ها).

צ- التشكيل : وهو وسيلة من وسائل التعبير لدى الأطفال يختلف عن وسيلة

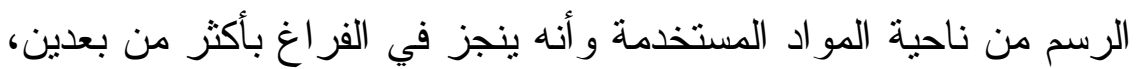

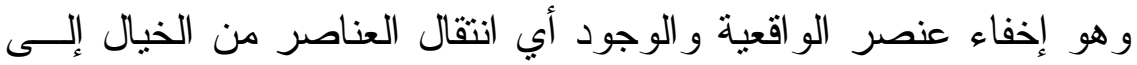

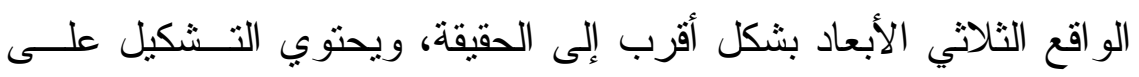

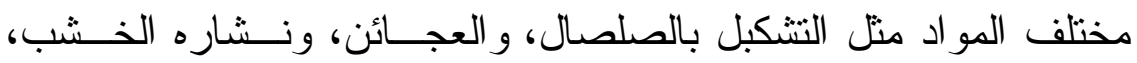

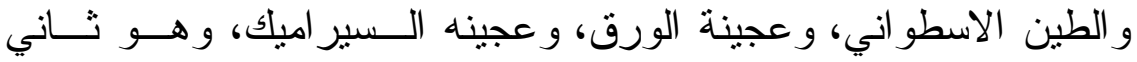

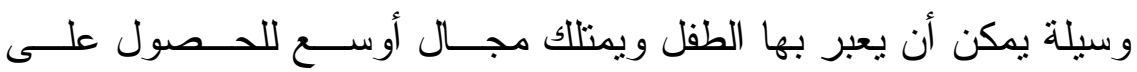


خبر ات اكثر، يتم فيه صنع نماذج مختلفة باستخدام خامسـات ومسـستهلكات البيئة وربطها ولصقها باستخدام العجين أو الصمغ أو غيرها من المــواد الاصقة.

ه- التركيب : عبارة عن عمل ثز اكيب فنيه ثتائية أو ثناثية الأبعاد من خلال

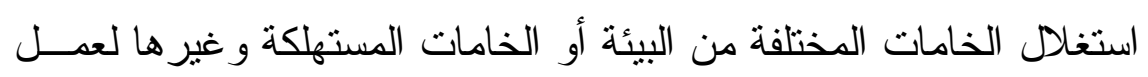
أثكال فنية يمكن أن تكون لها قيمة وظيفية أو جمالية.

צ- الطباعة : عبارة عن نشاط فني يهدف إلي تتميه الإدر الك و الإحسساسات

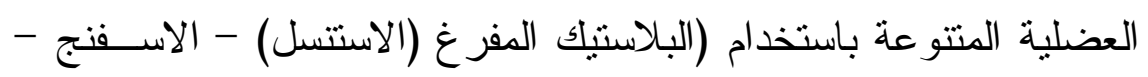

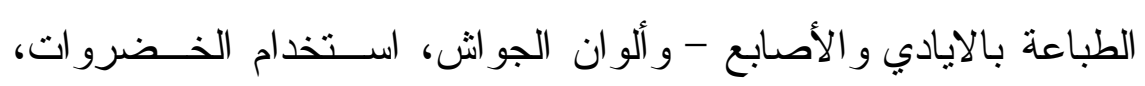
ورق الثجر ، أعو اد الكبريت، ، الورق المفرغ).

V-الكــولاج : استخدام خامات منتو عة من مستهلكات البيئة لتكـــوين صــور

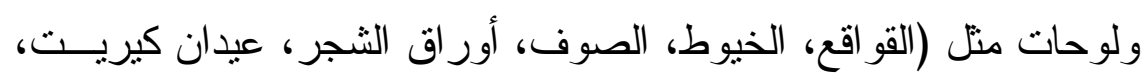

$$
\text { و غير ها من الخدمات). }
$$

وقد روعي في البرنامـج استخدام الأنشطة لتنمية قدرات المتعلمين فـي

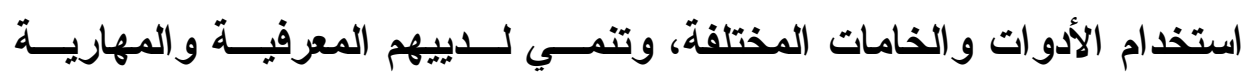
لاستخدام الادوات والمواد والتجهيزات بطريقه آمنه وصحيحة لإنتــاج أعمـال فنيه عن طريق تنفيذ الأنشطة الحرة والمنظمة، بذلك يتدرب المتعلمـين علـى إتقان أعمال الرسم والتشكيل بالطين وأن يتدرب على أعمال (الكولاج) والقص وله و اللصق وأن يتقن بعض هذه المهارات كل متعلم حسب اهتمامه. 
• دور المعلمة في استخدام الأنثطة الفنية لتنمية القـيم الاقتــصادية لطفـلـ الروضة : دور لمعة

من خلال إعداد البيئة المحفزة لممارسة الأنثطة الفنية حيث نقوم المعلمة

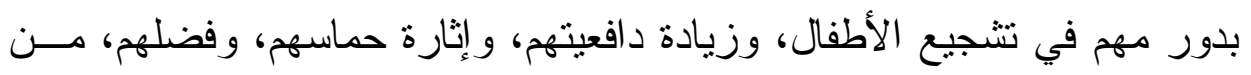

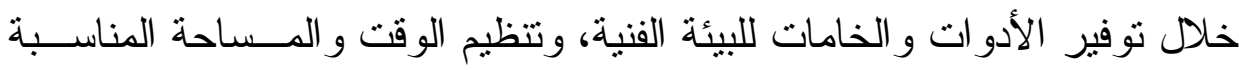

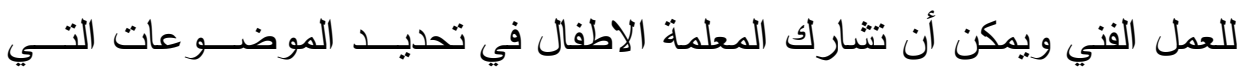

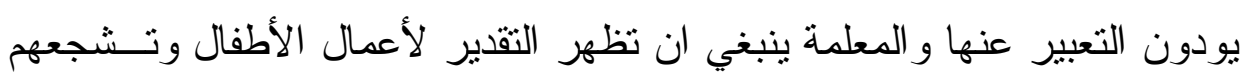

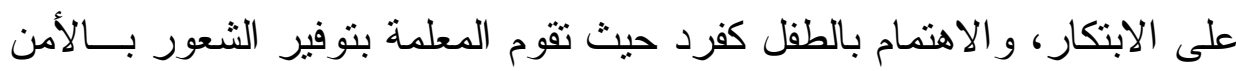

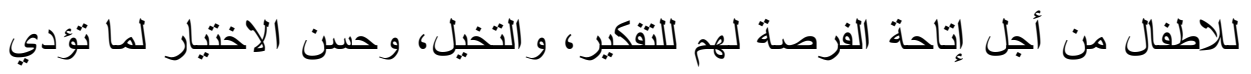

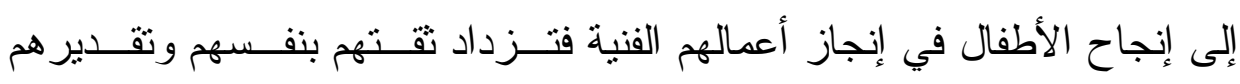
لذو اتهم.

ولذا روعي في أنشطة البرنامج أن تقـــوم المعلمــة بإتاحسـة الخبــرات

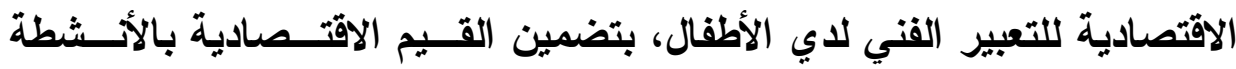

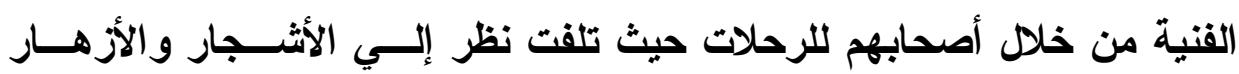

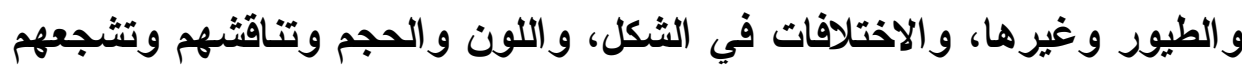

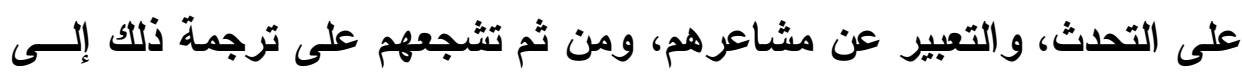

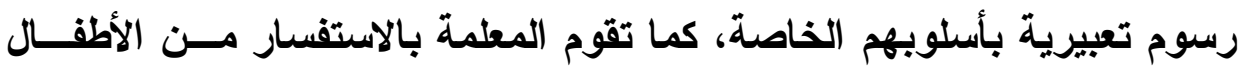

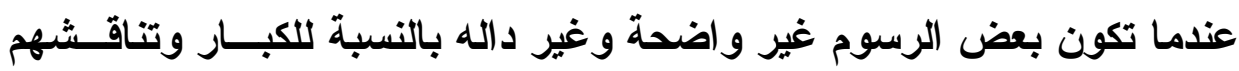

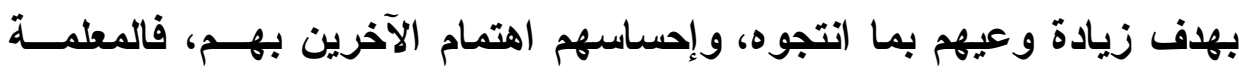

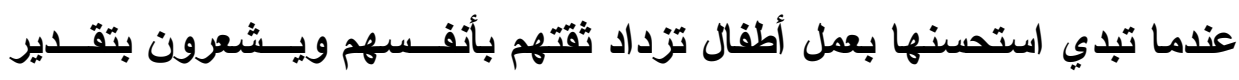

r المجلد الخامس


الآخرين بما ينتجونة، والاهتمام بعرض أعمال الأطفــال والاحتفــاظ بإنتــاجهم

وفي ضوء ما سبق فإن الأنشطة الفنية تعد أبرز أنــواع الفنــون التــي يمارس من خلالها التعبير الفني، سواء كان ذللك التعبير فكريا أم التعبير عـن

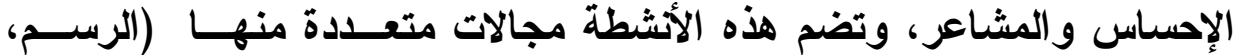
و التصميم، والكولاج، وغيرها من المجالات الفنية التي تساهم في بناء الفــرد وتكوينة من الناحية الاففعالية والنفسية من جهة ومن جهــة أخــري تنميــة الاتجاهات والميول و القيم بوجه عام والقيم الاقتصادية بوجه خاص، فالأشطة الفنية لغة رمزية ينقل من خلاهه الأطفال أفكارهم للأخرين، ولذا روعسي فــي البرنامج استخدام العديد من هذه الأنثطة بهذف تنمية القيم الاقتصادية مثــل ترشيد استخدام الخامات و الأدوات وغير ها. المحور الثاني : القيم الاقتصادية لطفل الروضة : تعد مرحلة رياض الأطفال من المراحل التربوية الهامة في تقدم أو تأخر

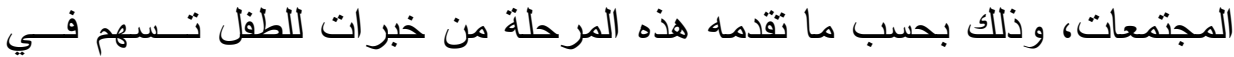

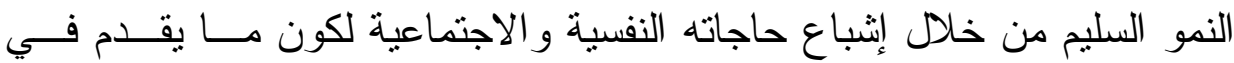

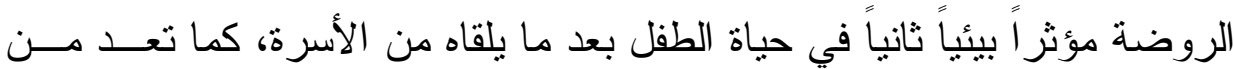
المر احل الأساسية الهامة في السلم التعليمي التي تمهد الطفل للتعطـيم الابتـــائي،

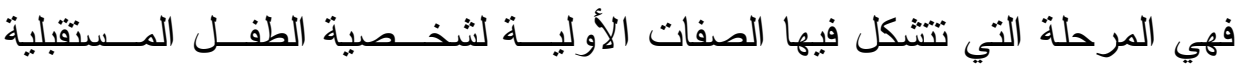
وتوسيع مداركة وتتعدد اتجاهاته وميولــه، ويـسـهل فيهــا اكتـسـاب المفــاهيم و المهار ات و العادات و القيم وتتكون من خلالها الأسس الأولية للمفــاهيم و التــي لهي

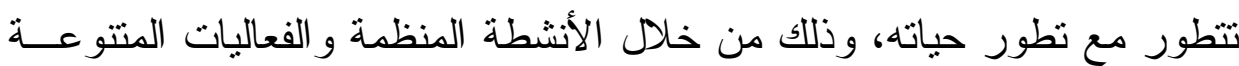

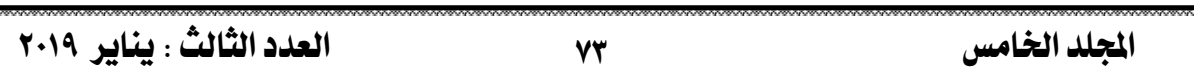


التي بمارسها و التي تمده بالكثير من الخبرات الجديدة، لذا ما يتعلمه الطفل فـي سنو ات عمره الأولى يؤثر سلبا أو إيجابا في سائر مر احل حياته.

فالتربية الاقتصادية هي من المجالات التي يتز ايد الاهتمام بها بشدة فـي

العقود الأخيرة، فكان من الضروري النظر إليها ودر استها في علاقتها بالاقتصاد

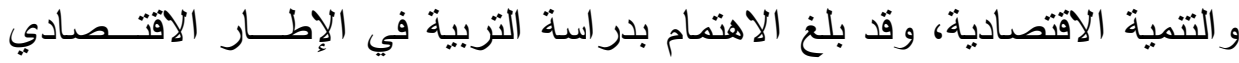

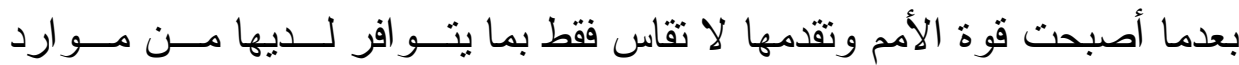

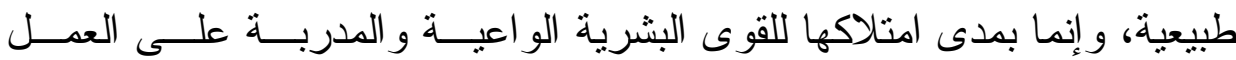

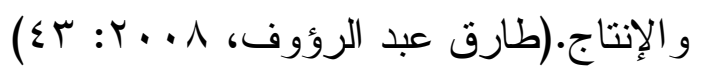
وفي الآونة الأخيرة تردد كثير اشعار (اقتصد)، وذللك نتيجــة للاخـتـال و العجز الاقتصادي الذي يعاني منه معظم بلاد العالم و الذي يعكس أهمية التتشئة

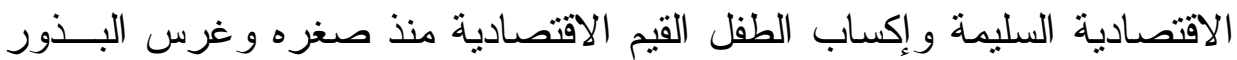

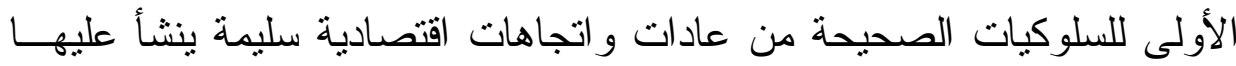

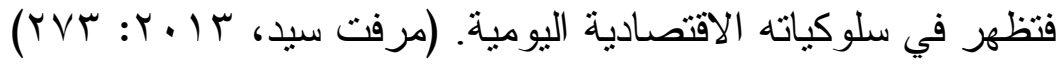
وبناء على ذللك فإنه من الضروري إكساب أطفالنا منذ مرحلـــة الطفولـــة

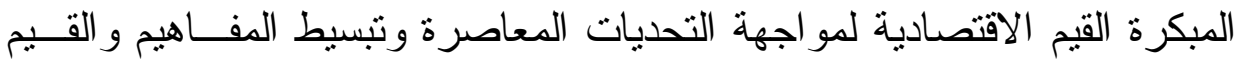
المرنبطة بها، الأمر الذي يفرض ضرورة الاهتمام بغرس بذور القيم الاقتصادية

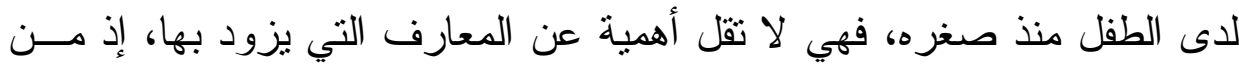

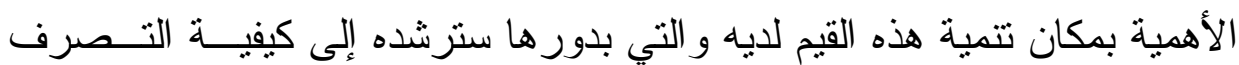

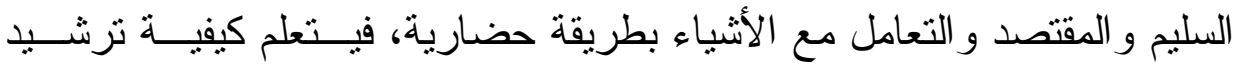

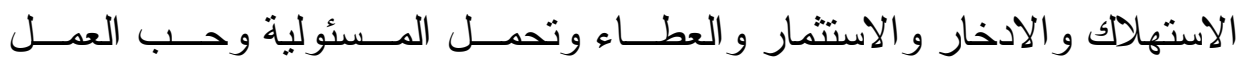

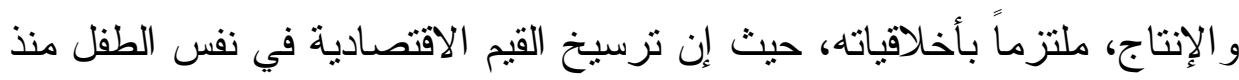

r المجلد الخامس


صغره سوف تظهر آثار ها في سلوكه مستقبلا وترسخ لديه العادات الاقتـصادية

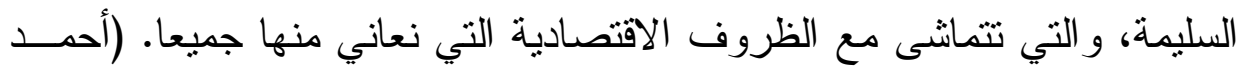

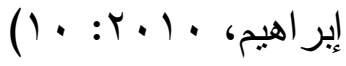

وتلعب بيئة الروضة دورا هاما في إكساب الطفل العديد مــن المهـار ات

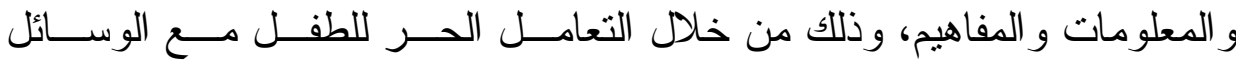

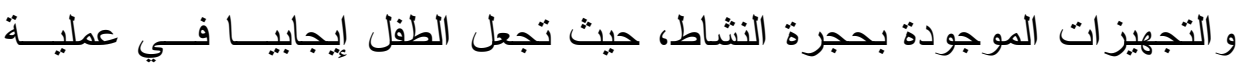

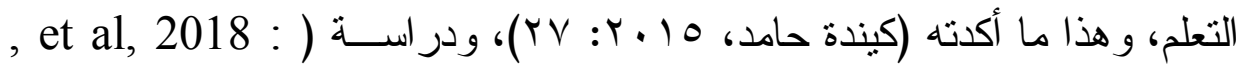
(Matthias Sutter57

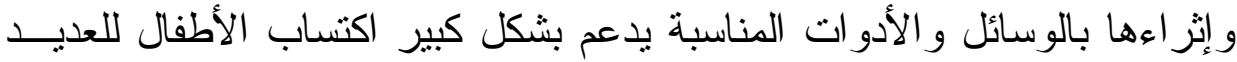

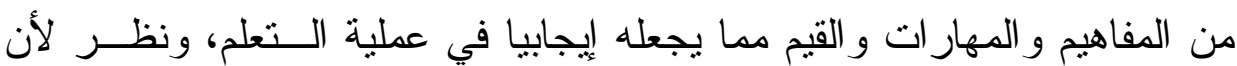

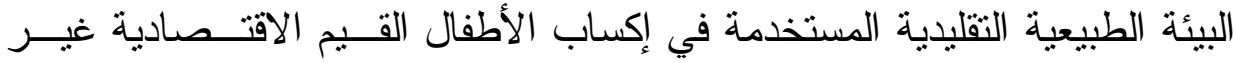

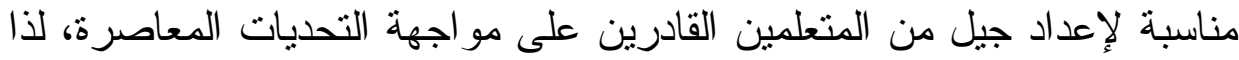

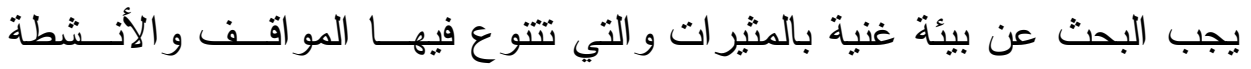
لضمان جودة مخرجات التعلم و إيجاد طرق أفصل لإثشر الك المتعلمين في عمليات التعلم، مما يجعل دور المعلم منحصر في خلق الموقف التعليمي وتــــفير البيئــة

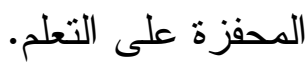

ولهذا ينصح معظم المتخصصين في الطفولة المبكرة بــرورة تطبيـق

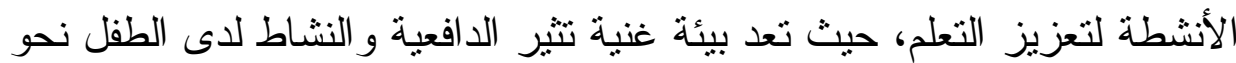

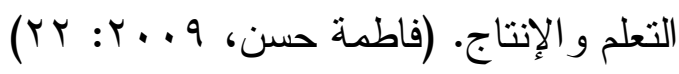

ومما يؤكد علي تز ايد الاهتمام بالقيم الاقتصادية وضرورة تتميتها لــدي

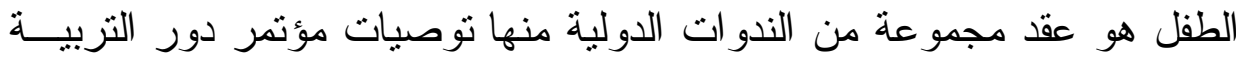




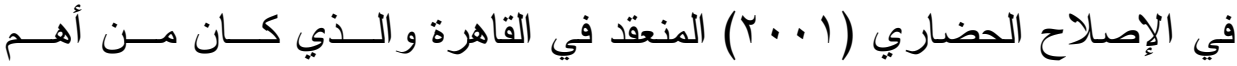

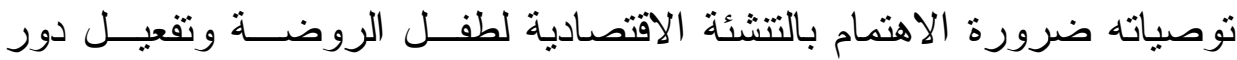

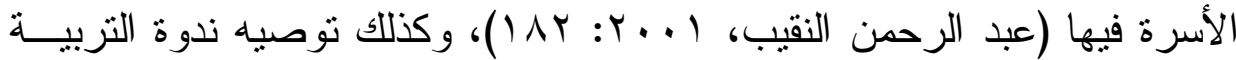

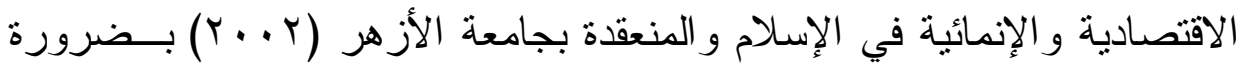

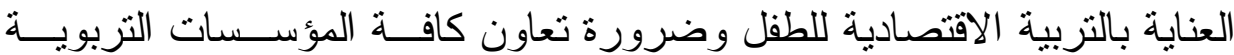

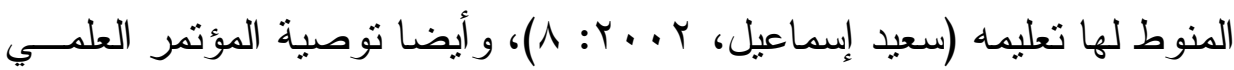
الدولي السابع لكلية التربية بعنو ان تربية الأبناء على مفاهيم الاقتصاد الإســلامي

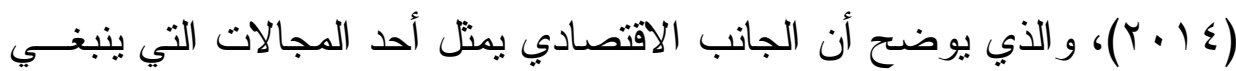

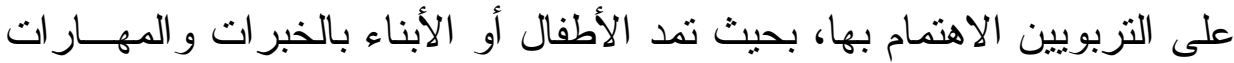

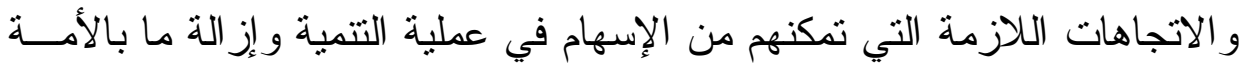
الإسلامية من تخلف، فالتربية الاقتصادية علم وفن، علم يدرس الجوانب التربوية التهاية

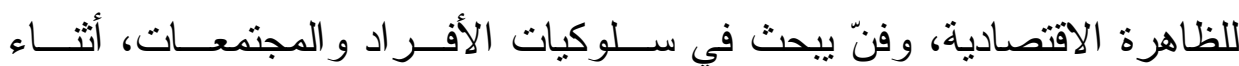

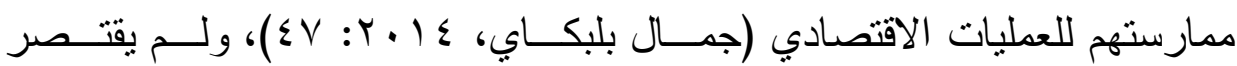
الاهتمام على المؤتمر ات فحسب ولكن امتد إلي المنظمات المدنية غير الرســية

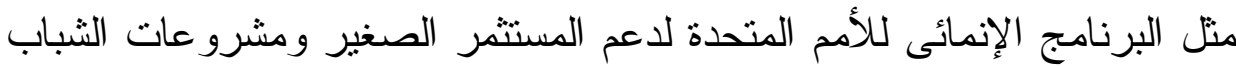

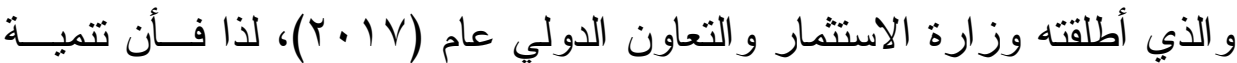
القيم اقتصادية أمر في غاية الأهمية ويجب تتميتها لدى الطفل، لكي يصبح لايسـه

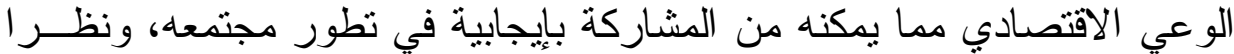

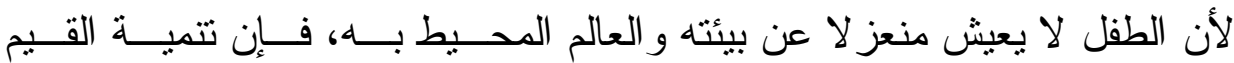
الاقتصادية يمنل حاجة ملحة في الوقت الر اهن. 


\section{• تعريف القيم الاقتصادية:}

تعرف القيم الاقتصادية بأنها "القيم التي تعبر عن ميل الفرد و اهتمامه بكل ما هو نافع ومفيد من أجل الحصول على الثروةو المنفعة، وللوصول إلــى هـــا الهدف يتخذ الفرد من عالمه المحيط وسيلة للحصول على الثروة وتغلــب علـى

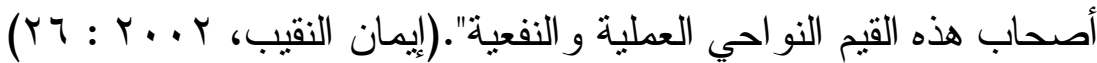

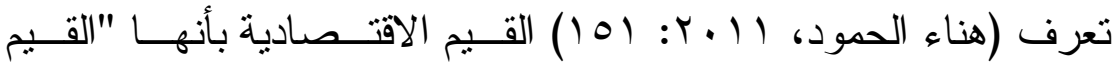
المتعلقة بالنو احي الاقتصادية في المجتمع منل: الربح، الخسارة، الثزوة، النقــود، الغنى، الققر ، وعادة ما نتبع هذه القيم من تجربة و اقعية من و اقع اقتصاد المجتمع

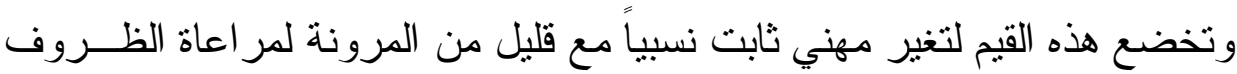
الاقتصادية التي تتغير في المجتمعات عبر الفتر ات الزمنية المتعاقبة". تعرف القيم الاثتصادية إجرائيا بأنها : "اهتمام الطفل وميله إلى ما هـــ

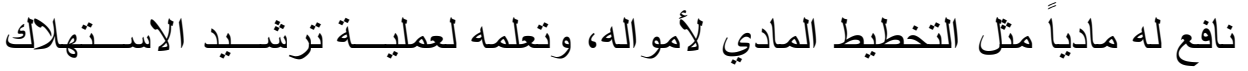
ولعملية الادخار وتقدير قيمة الوقت وحب العهـلـل اليـدوي و احتــر ام العـــال و أصحاب المهن وتقدير هم". - أهداف القيم الاقتصادية لطقل الروضة: تهدف القيم الاقتصادية إلى توعية الطفل بالقضايا و المشكلات الاقتصادية التي تو اجهه وتو اجه مجتمعه، و إكسابه أساليب السلوك الاقتصادي الرشيد لتحقيق أفضل تكيف ممكن مع الظروف الاقتصادية المتاحة، ويمكن أن تحقــق التربيــة

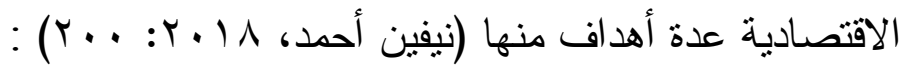
- تتمية إدر الك الأطفال لقيمة المال على أنه وسيلة وليست غاية. 
- - استثمار الوقت فيما هو مفيد، واستغلال الطاقات في العمل و الإنتاج. - تحقيق النمو الأخلاقي للطفل من خلال تمسكه بالقيم الأخلاقية الاقتصادية

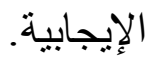
- - توعية الأطفال بالمشكلات الاقتصادية التي تو اجه الأسرة و المجتمع. - إكساب الأطفال العديد من أساليب السلوك الاقتــــادي الرشــبد لتحقيــق أفضل تكيف ممكن مع البيئة اقتصادية. - أهمية القيم الاقتصادية لطقل الروضة: للقيم أهمية خاصة في حياة الفرد و المجتمع، وتكوين القيم لدى المــتعلم لا لأل

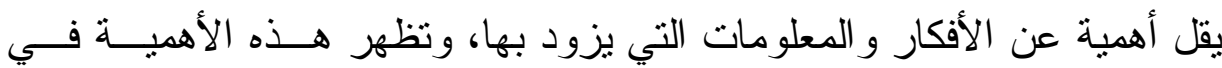

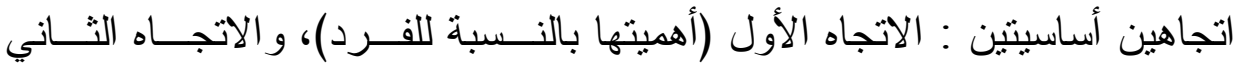

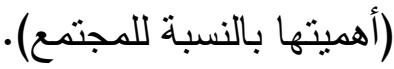
حيث تظهر أهميته القيم الاقتصادية بالنسبة للفرد في كونها تحدد للأفر اد اختبار ات معينة تحدد السلوك الصادر عنهم أي تحدد شكل الاستجابات، كما يمكن لهن

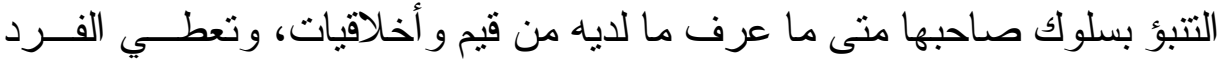

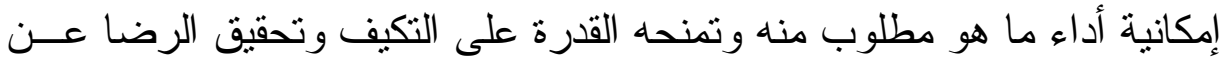
نفسه لتجاوبه مع الجماعة في مبادئها و عقائدها، كما تلعــب دور اً فــي تـشكيل شخصية الفرد فهي قوة دافعة للعمل، بالإضافة إلى أنها تمتل طاقات للعمل ودو افع

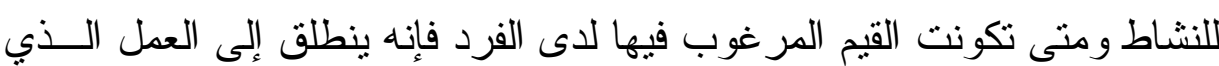
يحققها وتكون بمثابة المرجع أو المعيار الذي يقيم به هذا العمل. 
وتظهر أهميته القيم الاقتصادية بالنسبة للمجتمع في أنها تحــافظ علىى

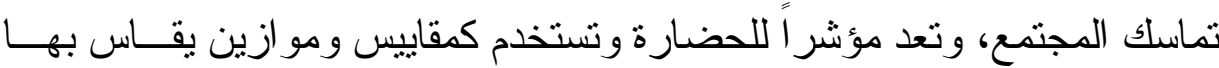
العمل ويقيم بمقتضـاها السلوك، وهي التي تحدد اتجاهات المجتـــع وتفـضيلاته وطرقه في ممارسة شؤون الحياة الأساسية كالتربية و التعليم و السياسة و الاقتصاد و العمل و غير ها من القضايا الاجتماعية ، حيث إن معرفة قيم المجتمع يفيد بالنسبة

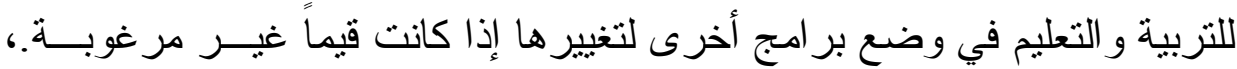

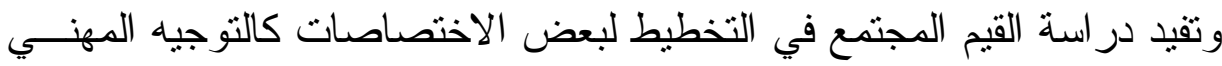

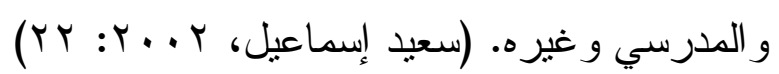

كما تتجلى أهية القيم في رياض الأطفال بالإضافة إلى ما سبق في أنه ينت في السنوات الأولى لعمر الطفل غرس القيم والاتجاهات وعن طريق تلك العطلية

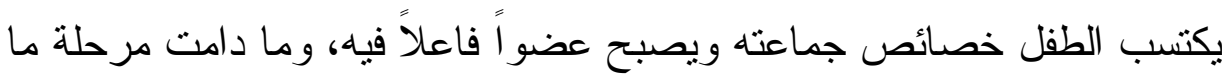

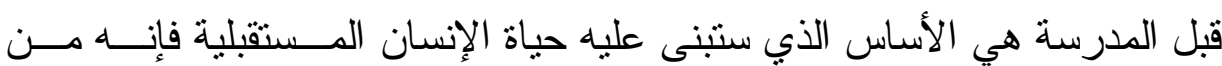

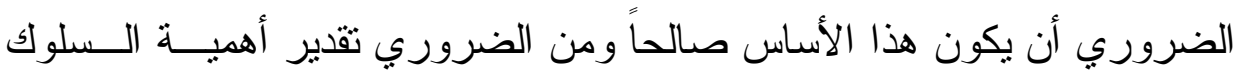

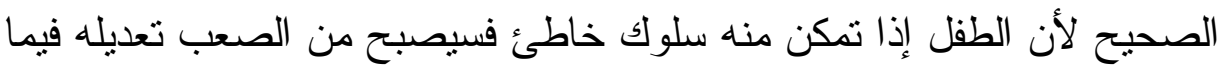

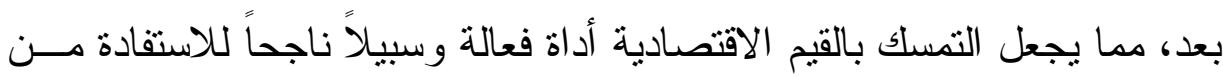

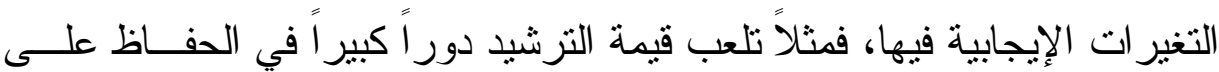

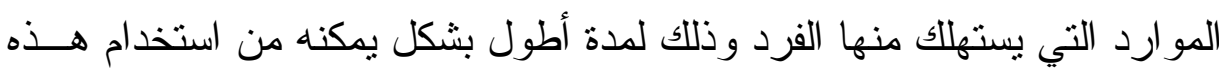
المو ارد لفترات لاحقة، حيث يمنع هذا الاستخدام هدر الموارد، وكذلك يفيد الإنفاق في تيسير الحصول على الحاجات و إعادة توزيع الثروة بشكل عادل بين الناس في

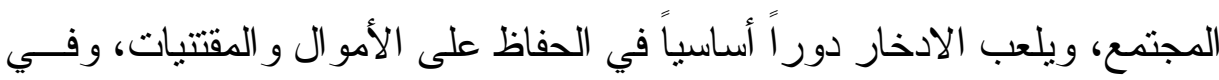

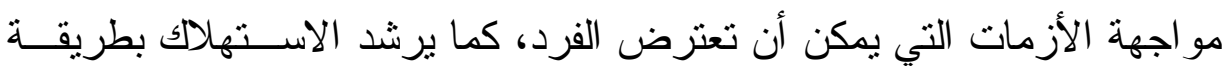

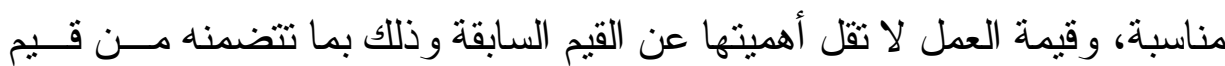


فر عية فالعمل هو السبيل إلى كسب لقمة العيش بطريقة شريفة وهو وسيلة لتلبيــة الحاجات الضرورية للفرد وسبيل لاستمر ارية الحياة، وكذلك قيمة احتر ام العمــال و أصحاب المهن تأتي أهمية هذه القيمة من أهمية قيمة العمل ومدى الجهد الــذي يبذله العامل أو صاحب المهنة لخدمة مجتمعه ونوفير حاجاته بشكل ينمي التر ابط بين المهن ويجعل من المفيد غرس بذور احتر ام العمال وتقدير هم لدى الفرد فـي

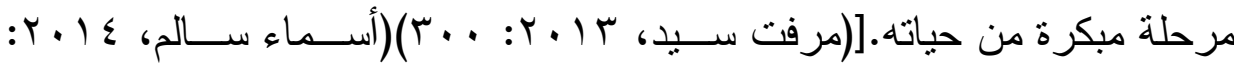

\section{• خصائص القيمة الاقتصادية :}

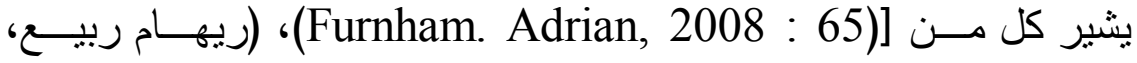

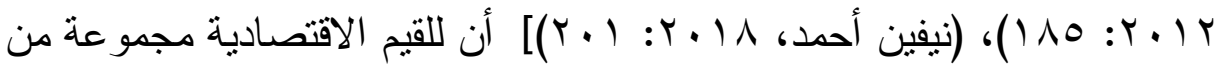
الخصائص التي ترتبط بمفهومها وتميزها عن غيرها من المفاهيم الأخرى وفيما يأتي أهم تلك الخصائص : (مكتسبة، قابلة للتغيير، تتمو وتزهر بالبيئة المناســبة، تجريبية، معيارية ذاتية، ظاهرة نسبية).

يتضـح من الخصائص السابقة للقيم أنها صفات ير غب بها الناس في إطــار ثقافتهم و هذه القيم قد تختلف من مجتمع لآخر وربما تختلف في المجتمع الواحد فما يصلح من قيم في زمان ومكان معين قد لا يصلح في مكان وزمان آخــر ورهـــا يرجع إلى خصوصية القيم وخصائصها المتتوعة. (هنية محمود، س ا ـ Y: 0؛) وما ينطبق على القيم الاقتصادية بشكل عام ينطبق على القيم في رياض الأطفال مع فارق بسيط ينشأ عن طبيعة القيم في مرحلــة الريــاض، وتحــــاول الباحثة أن تحدد الخصائص المميزة للقيم في هذه المرحلة بناء على ما ســبق هـ فيما يلإي: 
- - تمتاز القيم في هذه المرحلة بأنها أقل تجريدا بالنسبة للطفل وهي كما تبين

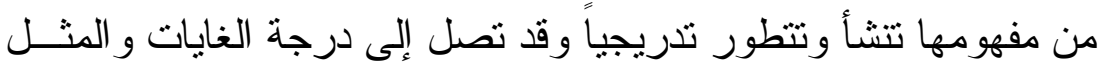
العليا عند الكبار بينما تبدأ عند الطفل عن طريق تعريفه بما هو صــائب وما هو خاطئ لذا فإن درجة التجريد التي تتمتع بها عند الكبير تختلــــ عنها عند طفل الروضة. - تعد أقل معيارية فربما يكون اتخاذ الفرد الر اثد قراراً وفقاً لقيمة معينــة يتبناها أكثر إلز اما ومعياريةً لديه من طفل الروضة الذي يحتاج بصورة دائمة إلى إرشاد وتوجيه كي يتغلب الجانب الإيجابي من القيم لديه علــى الجانب السلبي منها، ولذلك فإن درجة المعيارية وكونها ميز انا بـستطيع أستع الطفل أن يقيم ويقيس الأمور وفقه أو أن يتوصل إلى إصدار حكم أو اتخاذ قر ار بناء على المعايير السائدة، هي أقل عنده.

- - القيم التي يتعلمها الطفل في هذه المرحلة تتسم بالثبات النسبي لديه : فمـــا يتلقاه الطفل من قيم سو اء كانت إيجابية أم سلبية تتعزز لديه، وهنا تكمن أهمية أن يتلقى الطفل القيم الإيجابية في المناهج المقدمة له. و على الرغم من أن القيم لدى الطفل في هذه المرحلة تكون أقل تجريـــاً

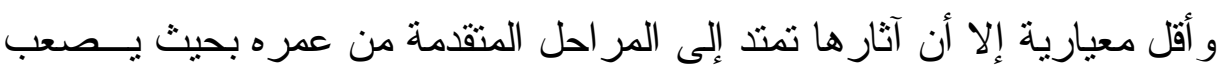
تغيير القيم التي تغرس في الطفل فيما بعد وخصوصاً إذا كانت قيما سلبية ولعـلـل هذه خاصية مميزة للقيم في هذه المرحلة، وتستمد القيم الاقتصادية خصائصها من خصائص القيم بشكل عام وتتفرد في خاصية مميزة لها حيث تبدو أكثر وضوحاً و هي: "مرونة القيم الاقتصادية أي استجابتها لحاجات المجتمعات الثابتة و المتجددة

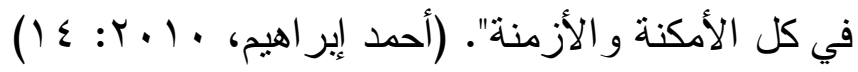


وفي ضوء ما سبق يتضح أن من أهم خصائص القيم الاقتصادية أنه إذا ربي الطفل عليها يمكن أن يتعود منذ الصغر على المرونة في الخبرات العملية

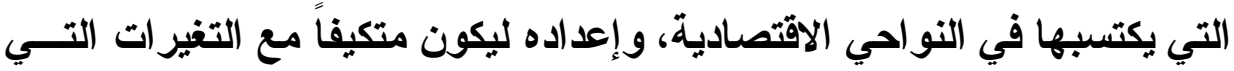
تطرأ على المجتمع وعلى شؤونه وخصوصاً من النواحي الاقتصادية، وتسهيل اكتسابه للاتجاهات و العادات الاقتصادية السليمة. • وظائف القيم الاقتصادية :

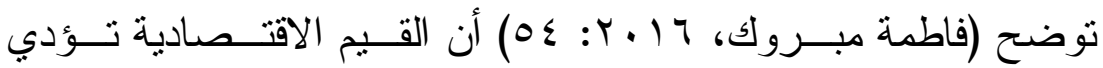
مجمو عة من الوظائف تتمثل أهمها في تمنح الطفل شعور نابع من الداخل كموجه

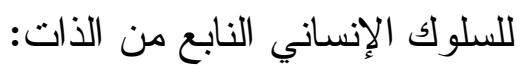
- تمكن الطفل من ضبط نفسه، وتحديد نوقعاته من رود فعل الآخرين. - تزود الطفل بالوعي المناسب لمعرفة الأمور، وموازنتها، و التمييـز بــين

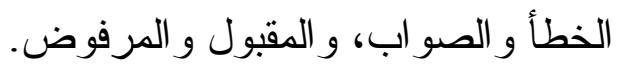
- نولد القيم لدى الطفل إحساساً بالصو اب و الخطأ. - ل لها دور في مجال التوجيه و الإرشاد النفس للطفل. - - نتكل إطار اللجماعة، ومعايير تصرفاتها. - - تشكل نمطا من أنماط الرقابة الداخلية. - تساعد المجتمع على دو اجهة التغييرات التي تحدث فيه وتحدد الهـسارات

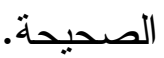




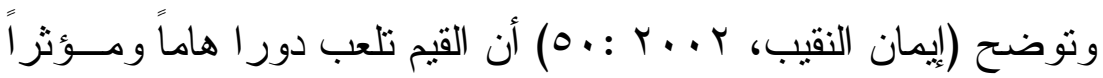

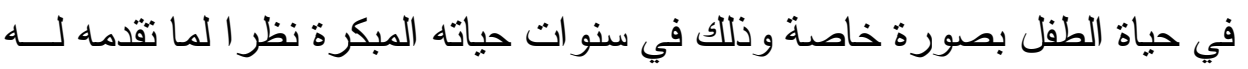

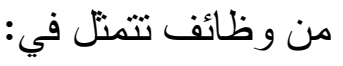

- تساعد الطفل على الارتباط بمجتمعه فيتكون لديــهـ الــــعور بالتماســــ

$$
\text { الاجتماعي و الانتماء للجماعة. }
$$

- - تساعد الطفل على فهم الأدوار الاجتماعية ومن ثم أدائها أداء ناجحاً. -

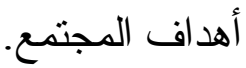

فأهمية القيم تكمن فيما تؤديه من وظائف وذللك بالنسبة للفرد و المجتــع

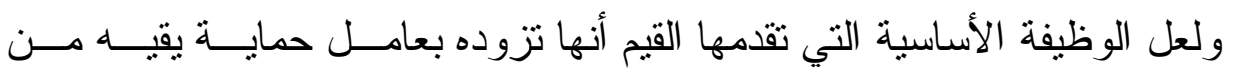

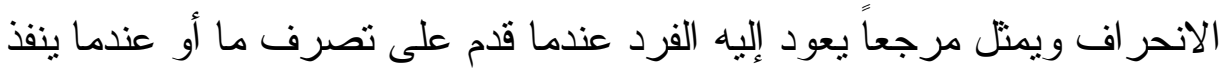

سلوكاً معيناً وبالتالي يستطيع الفرد أن يتشرب قيم مجتمعه ويعمل إلي تحقيقها.

\section{• القيم الاقتصادية المناسبة لطقل الروضة :

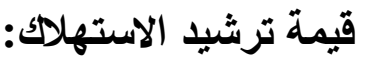

يعرف ترشيد الاستهلالك بأنه "اعتماد ســلوك مـستقيم تجــاه الأنـــواع

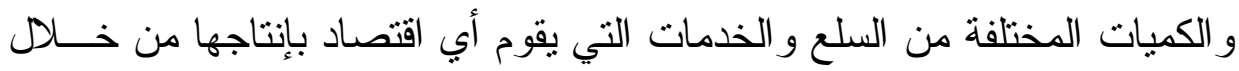

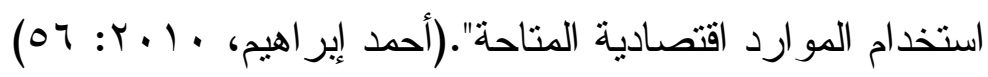

كما تعرف بأنها: "حسن استغلال الموارد المتاحة وعدم الإســر اف فـي

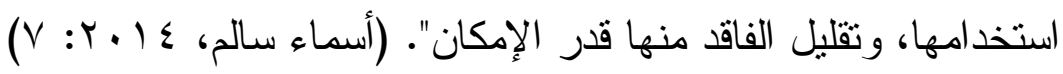


ولترشيد الاستهلاك أهمية كبرى منها تقويم العادات الاستهلاكية الـسيئة

كالإسر اف و التبذير ، وتكوين عادات استهلاكية سليمة كالاقتصاد فــي المــوارد المتاحة، وتكوين الوعي الاستهلاكي الذي يمكن الفرد من التصرف بحكمة فـي

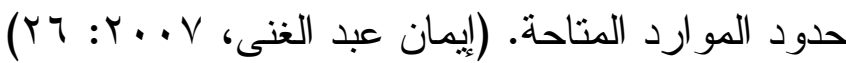
و لا جدال في أن البعد عن ترشيد الاستهلاك يوقع المجتمع في المهالك، فالسلوك الاستهاكي إذا انحرف في طريق الإسر اف وز ادت المبالغة في طلـبـ السلع و الخدمات، فسوف يعجز الإنتاج عن تلبية الطلب على السلع و الخــدمات، فيختل التو ازن بين الإنتاج و الاستهلالك مما يؤدي إلى مشكلات اقتـــــادية منهـــا

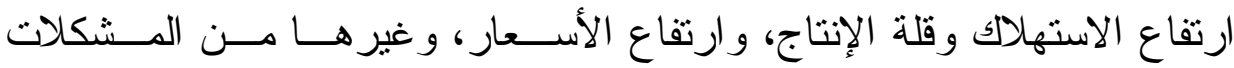

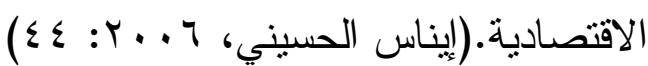

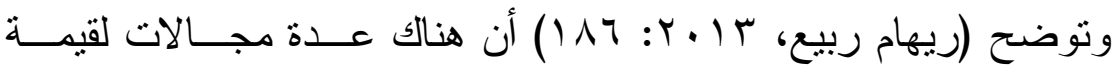
تزشيد الاستههلاك منها: (ترشيد استهلاك الماء، ترشيد استهالاك الغــذاء، ترشـــيد استهالك الطاقة، ترشيد استخدام الورق، ترشيد استخدام الهاتق). قيمة الإقفاق:

إن الوقت الذي يبدأ فيه الطفل إدر الك النقود أفضل وقت لتعليمـــه كيفيــة إدارتها، وكيفية إنفاقها، فمن الضروري أن يتزبى الطفل على أن النقود لقـــاء الحاجات الهامة و الاستفادة من النقود في تيسير أمور الحياة اليومية، وكذلك دور النقود في مساعدة الآخرين بالفائض عن حاجاتتا، أو إيثار الآخرين الأكثر حاجة منا على أنفسنا، فيتدرب الطفل منذ صغره على مساعدة الفقــر اء بمـــا يــستطيع

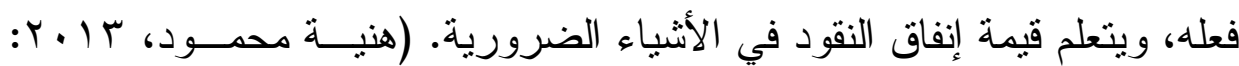


فالحياة اليومية تستوجب من الفرد الإنفاق في كل يوم إن لم يكن ذلك عدة

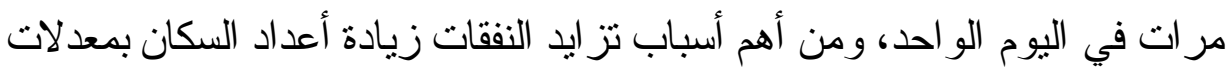
عالية وتز ايد منطلباتهم وتطور حاجياتهم هذا بالإضافة إلى جنوح معظمه إلـى الـى الابتعاد عن الحياة الزر اعية و الحرفية المنتجة وتفضيلهم الأعمال المدنية الأقل تعباً

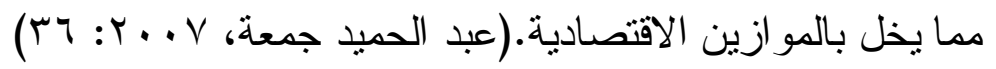

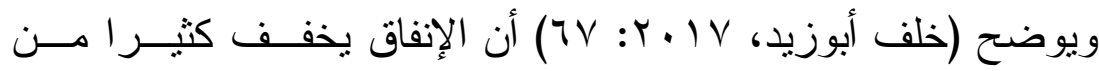
الفوارق المادية بين الأفراد ويقيم التو ازن النسبي بين الفئات المختلفة من حبــث الفي

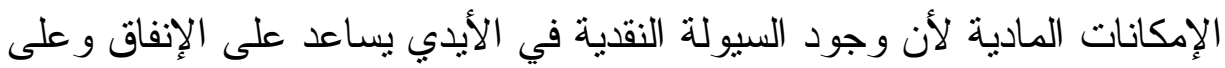

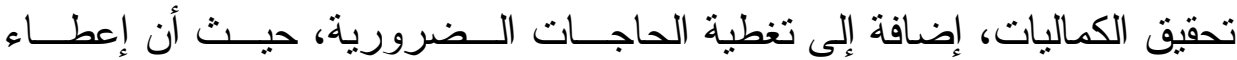
الأغنياء جز ءاً من أمو الهم للفقر اء يساعدهم علي الإنفاق، وللإنفاق آثار اقتصادية

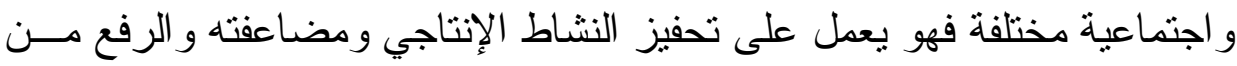
معدلات الطلب و العمالة وتز ايد الثروة ومن أهدافه: - - العدل و المساو اة: أي العدل في توزيع المال بعيداً عن الإسر اف. - - هو الضمان لحسن توزيع النزوة بين جميع الافر اد. - - يؤدي إلى قيام مجتمع متكافل قو امه التعاون الإنساني مما يعمل على زيادة

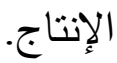
- - يؤدي إلى التتمية الاقتصادية المتكاملة.

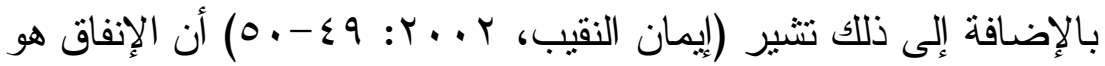

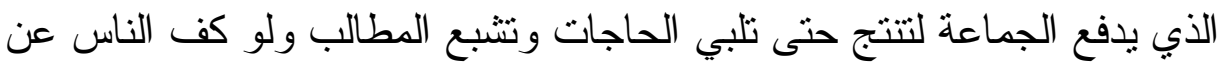


الإنفاق أو الاستهلاك و غلب عليهم الثح و الإمساك لتعطلت عجلة الإنتاج وتــأخر المجتمع عن غيره لعدم وجود قوة شر ائية تستخدم ما ينتج من سلع.

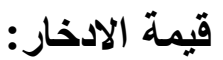

تعرف (كوثر الثاذلي، ؟ ا.ب: ع) الادخار بأنه "الجزء غير الدستهلك

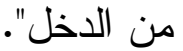

ويعرف (33 : Mary \& Bonnie, 2005 ( 23 على أنه "الجزء من الــدخل الذي لا ينفق على السلع الاستهلاكية والخدمات، وتخصص للادخار، وهو الفرق

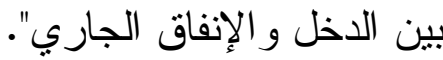
كما تعرفها أيضا (كيندة حامد، 10 • r: 07 بأنه: " اقتطـــاع يـستهدف

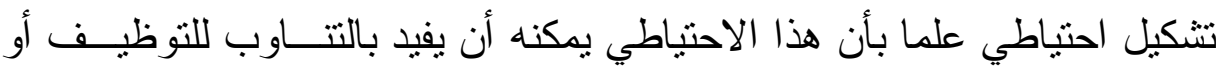

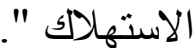

كما يعرف أيضا ( 54 : Michael, 2011 بأنه "احتفاظ الفرد بمبلغ من

المال للاحتياط أو الاستثمار".

ويعتبر الادخار ظاهرة اقتصادية قديمة، ولقد زاد الاهتمام بمسألة الادخار

في المرحلة المعاصرة بسبب الاهتمام المتز ايد لمسائل النمو الاقتــــادي، وفــي البداية كان الادخار و اجبا و امتياز ألفئة قليلة ثم ما لبثت الطبقة المنوسطة أن أخذت الته تمارس الادخار بعد أن بدأت عمليات التنمية حيث أخذت نظهر منظمات و هيئات مختصة بمسائل الادخار كبنوك الادخار و التوفير وصناديق المعانشات و التــأمين

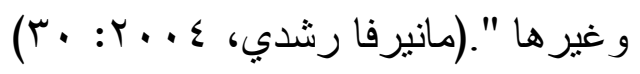




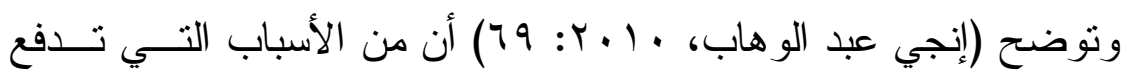

$$
\begin{aligned}
& \text { الفرد للادخار كثيرة وهي: - الجي: }
\end{aligned}
$$

- الاحتر اس: وهو ما يدفع الأفر اد إلى تكوين احتياطي لمو اجهة الحسـو ادث

$$
\text { غير المتوقعة. }
$$

- - الحيطة : تكوين احتياطي لمقابلة الظروف المتوقعة التي تغير النسبة بين دخل الفرد وحاجاته الثخصية كالثشيخوخة و التعليم و الإعالة.

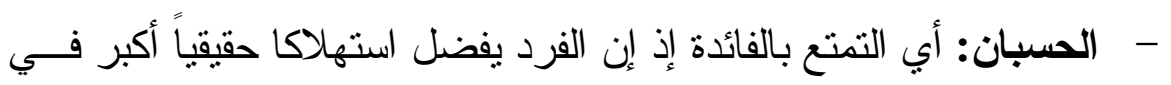

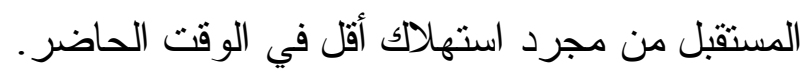

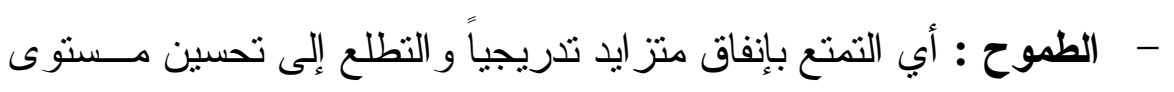
المعيشة.

$$
\text { - - المبادرة : القيام بالمشرو عات الاقتصادية. }
$$

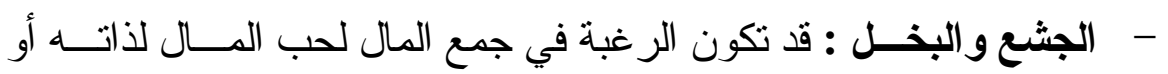
لإثشباع غريزة البخل لإى بعض أفر اد المجتمع.

ويشير (99: Matthias Sutter, et al, 2018 أن للادخار عدة أنو اع منها إما أن يكون :

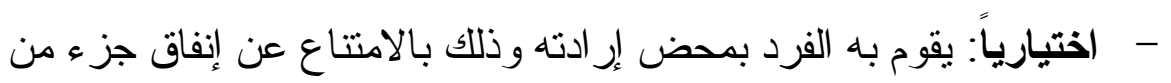

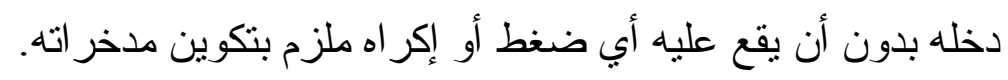

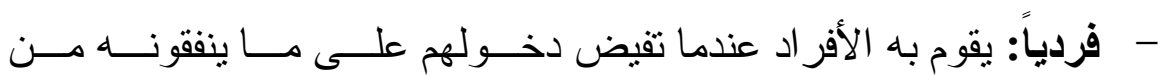
الاستههلاك.

- جمعياً: تقوم به الثركات أو الحكومات لأغر اض التتمية الاقتصادية بشكل عام. 
ويتضح مما سبق أن الادخار هو اقتصاد الجزء الزائــــــــن الـــخل

وتوفيره و المحافظة عليه و إنفاقه وقت الحاجة إليه في المستقبل، وعليه فـإنان عملية الادخار تتطلب وعيا وتربية لكافة المراحل العمرية والطبقات الاجتماعية

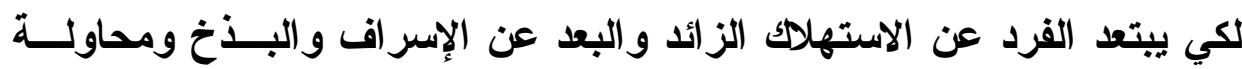

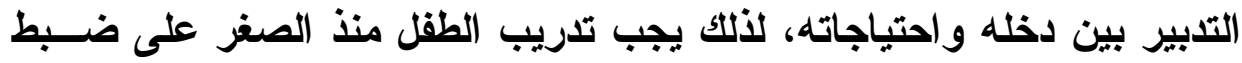

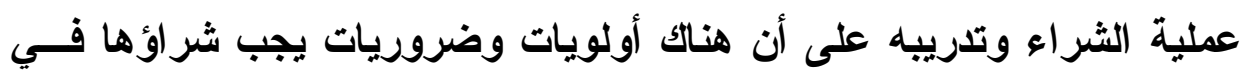

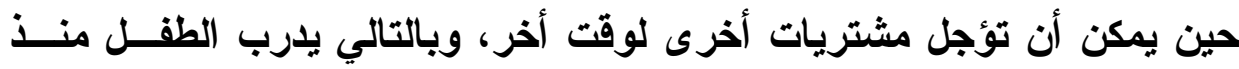
الصغر على السلوك الادخاري.

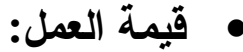

العمل ظاهرة طبيعية نشأت تلقائيًا في الحياة الإنسانية منذ بدء الخليقة بهدف مو اجهة أعباء معيثة الإنسان، وقد ارتبط مفهوم العمل بمجموعة من المهن داخل

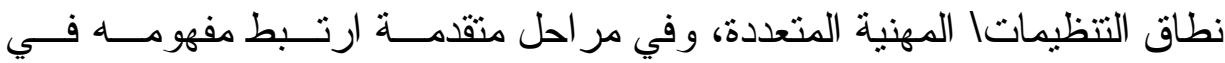

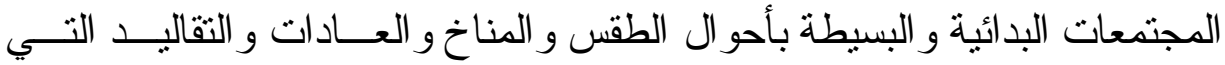
تعيشها تلاك الجماعات، حيث يقوم العمل على أساس التمانل و التثابه بين الأفر اد باد و هذا على العكس من مفهوم العمل في المجتمعات الحديثة التي تتميـز بالتخــاير

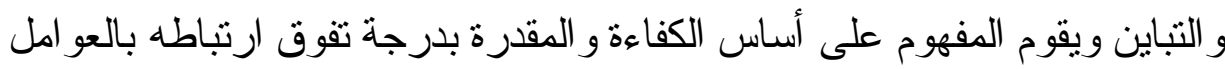

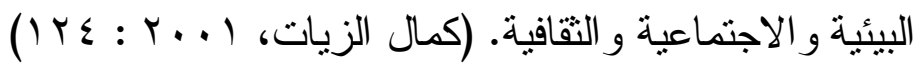

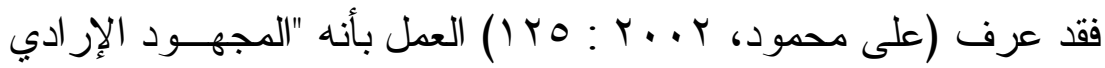

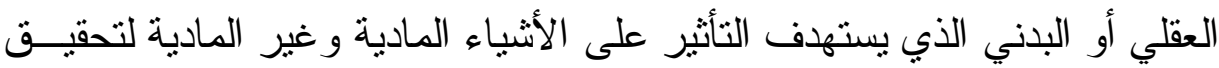

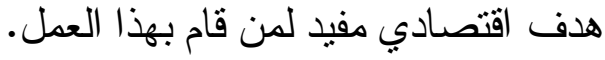


ومن ثم يمكن التوضيح أن العمل هو "الجها أو الطاقـــة اليدويــة أو

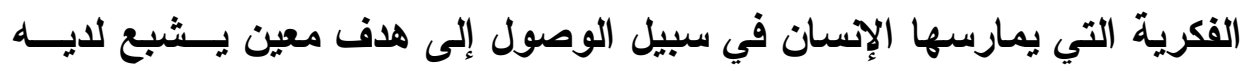

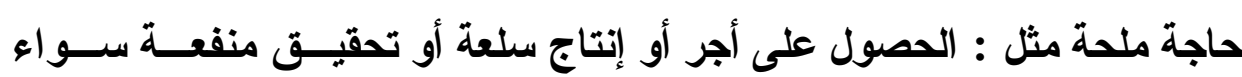

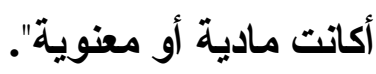

\section{قيمة أصحاب المهن وتقدير هم:}

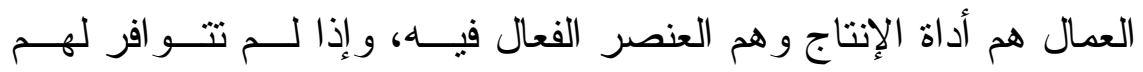

الظروف المناسبة فإن ذللك سينعكس على جودة العمل وجودة الأداء فـــي إتقــان

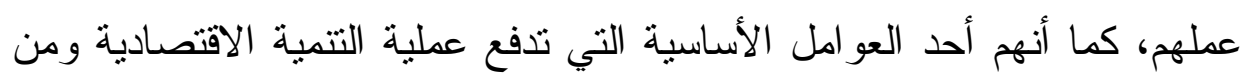

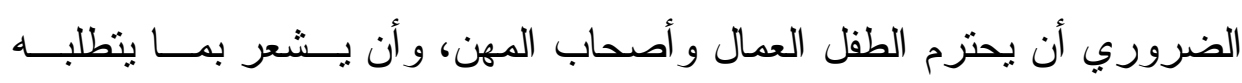

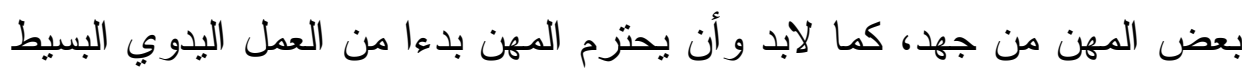

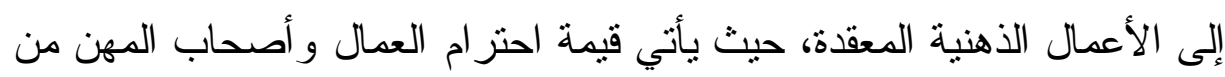

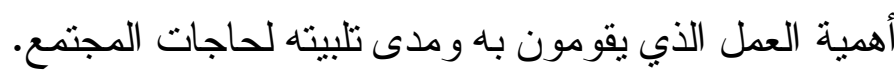

لذا وجب علينا معرفة المفردات الأساسية لهذه القيمة وهـــ (العامـل -

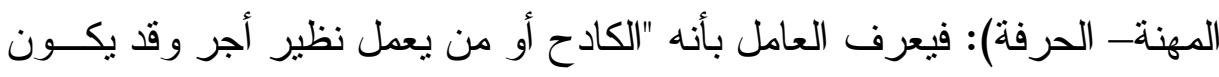

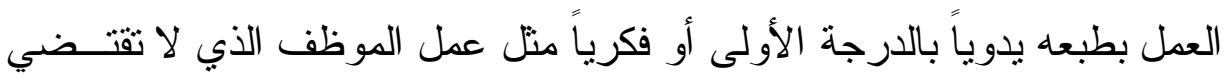

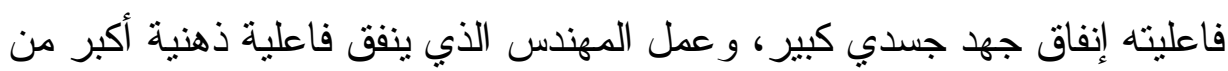

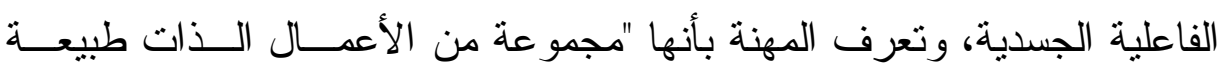

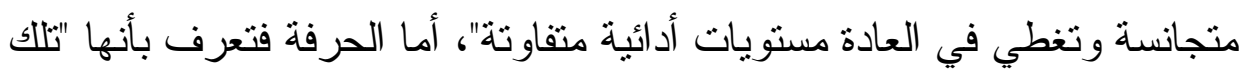

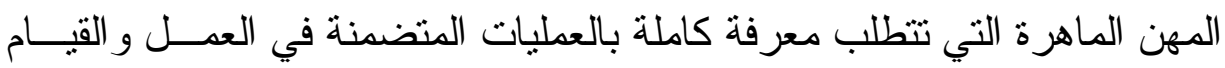
بأحكام مستقلة ومنطقية، كما تتطلب عادة درجة عالية من المهارة اليدوية وفـي لئي 


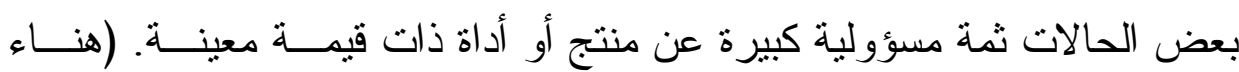

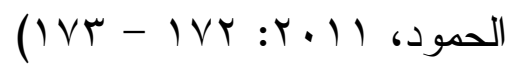

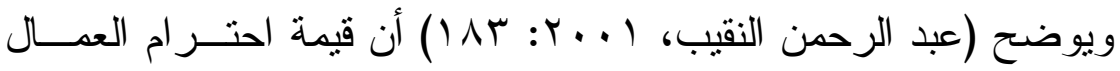
تتضمن معرفة أولية بأبسط حقوقهم وهي : - حماية العامل من كل عيب أو ظلم يقع عليه. - رعايته و العناية به صحياً وتدريبياً وفكرياً وتثقيفياً - إعطاؤه أجره كاملاً غير منقوص فور فر اغه من عمله. - معاملته بالعدل و التزفق بـه و عدم إر هاقه في العمل. - تحديد ساعات العمل له.

- توفير الرعاية الاجنماعية و الحماية من مخاطر العمل الناثنئة عن العمل. - أن يعوض العامل إذا عمل في ساعات ر احته و أن يوفر له التكافل و التأمين ضد العجز وضد الثيخوخة وأن يكون تكليفه بساعات العمل فـي حــدود

$$
\text { إمكانياته. }
$$

- توزيع العمل بين العمال وتوفير العلاقة الطيبة بين صاحب العمل و العامل. - توفير العمل الذي يتتاسب مع قدرة العامل وما حصل عليه من خبر ات وما اكتسبه من معارف، و العمل في ظروف عادلة و التمتع بالر احـــة الجـسدية لأنها و اجبة لاسترجاع نشاط العامل وقدرته على العمل.

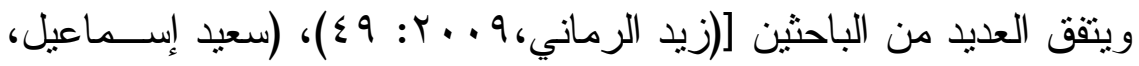

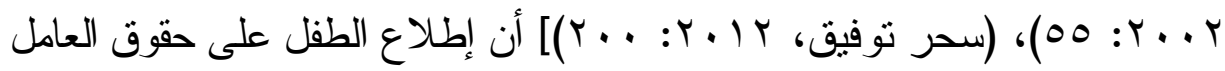


و الصفات التي يجب أن يتحلى بها وذللك بشكل مبسط و على نحو يستطيع الطفـلـل

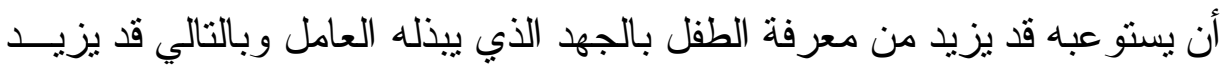

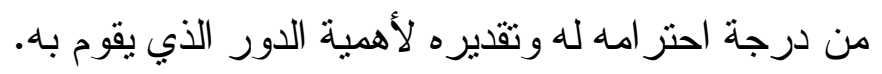

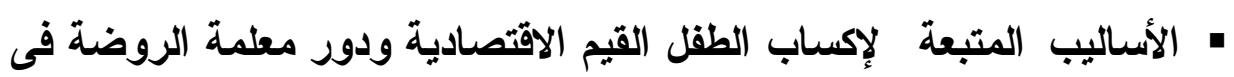

\section{تنمبتها:}

انطلاقاً من أن المعلمة تمنل من وجهة نظر الطفل بديلا وامتــدادا لــدور

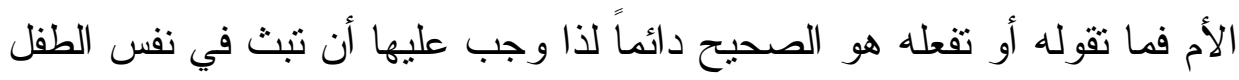

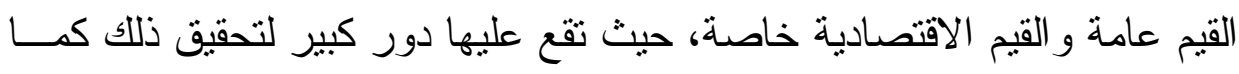

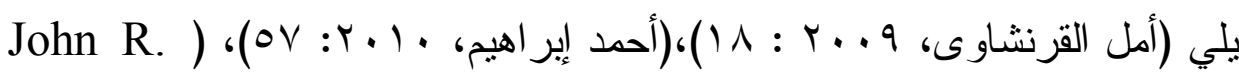

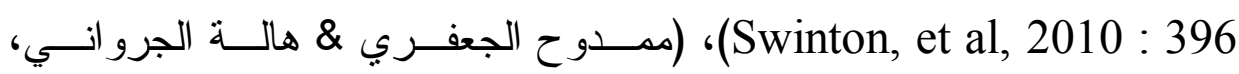

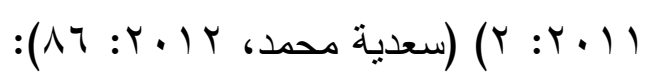

- تتمية مختلف جو انب شخصية الطفل دينياً وخلقياً بمعرفة القيم الاقتــادية

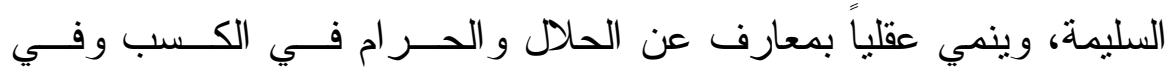

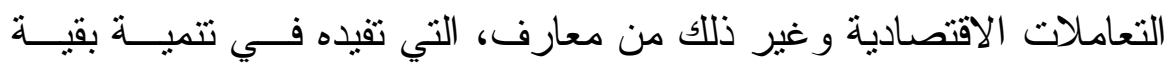

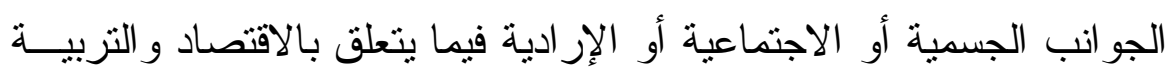
الاقتصادية.

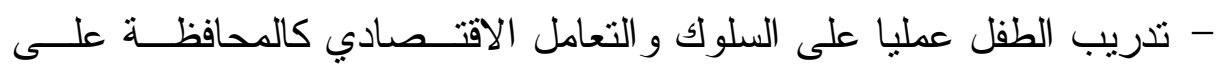

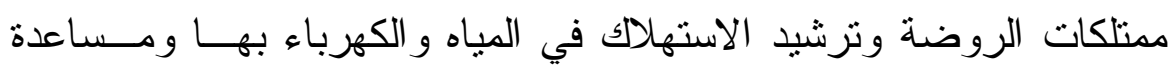

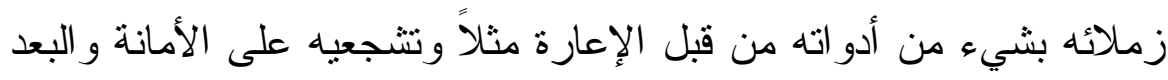
عن السرقة وما إلي ذلك من سلوكيات اقتصادية عملية. 
- تقديم الأنشطة المختلفة والتي تبث من خلالها مفاهيم وســلوكيات التربيــة

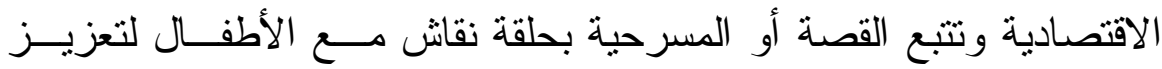
السلوكيات الايجابية التي تعلمو ها من خلال النشاط.

- يجب على المعلمة أن تبث في نفس الطفل معنى الادخار و الهدف منه مسـن خلال الملصقات و الأناثيد لفترة حتى يعطي النتيجة المر غوبة لالية

- تبسيط بعض مفاهيم السلوكيات الاقتصادية للطفل مثل التبــر ع، التخطــبط،

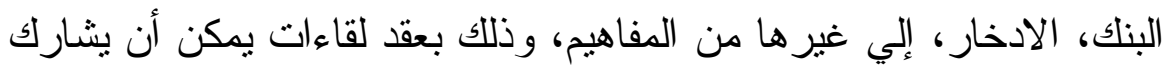

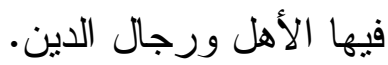

- متابعة الأطفال في الحفاظ على الممتلكات العامة و الخاصة داخل وخــارج

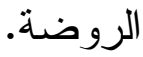
- توعية الطفل بالمجالات المختلفة لترشيد الاستهلاك من ماءوطاقة. - توعية الطفل بأهمية المحافظة على أدوات الروضة وترشيد استهلاكه مـن الخامات المتتو عة الني تقدمها له المعلمة في الأنشطة المختلفة. - اصطحاب الأطفال إلي زيارة لأحد المحال التجارية لتدرييهم على التعامـل

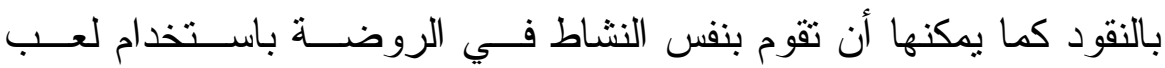

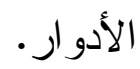

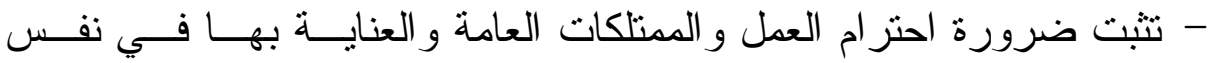
الأطفال ولتكن في نفسها أسوة حسنه لأطفالها. - إعداد بعض الأنشطة التخيلية و التي يدرك الأطفال من خلالها أهمية ترشيد

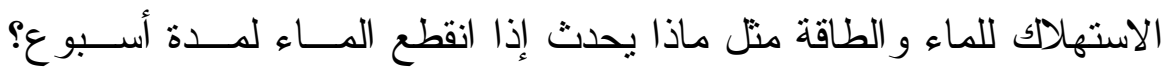
و هكذا. 
- إعداد الألعاب التعليمية لتتمية السلوكيات الاقتصـادية لدى طفـلـل الروضـــة

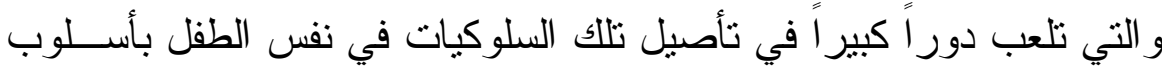
سكل ميسور

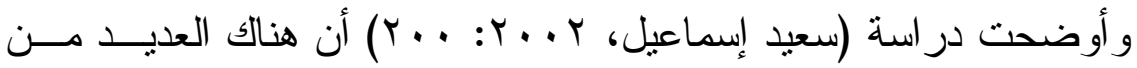

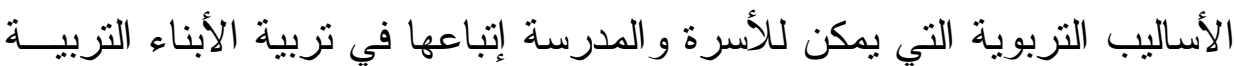

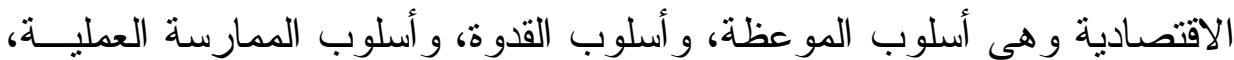

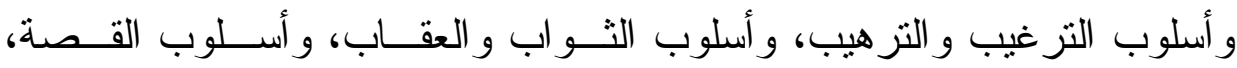
و أسلوب الأمثال، وقد أوصت الدر اسة الآباء و المعلمين أن بضعو ا نصب أعبنه في كل ما يربون عليه الأبناء تحقيق العبودية الخالصة لله تعـالى فـي المجــال

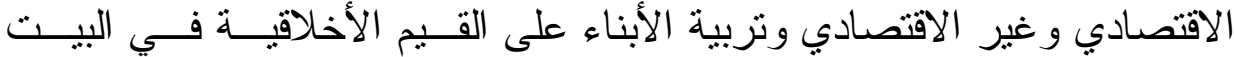

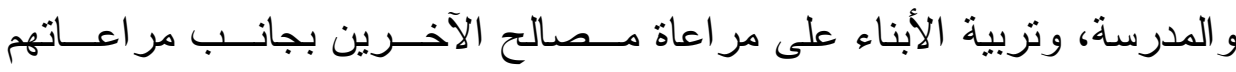
لمصالحهم و أيضاً مر اعاة مصالح الأمة الإسلامية و العالم بأسره.

ومن خلال العرض السابق يمكن توضيح أن معلمة الروضــة تمـــس

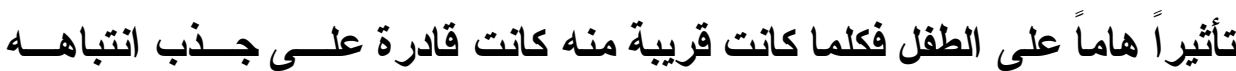

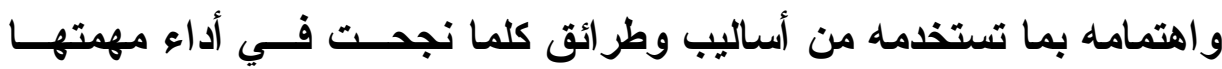
التربوية، وعندما تستخدم المعلمة الأساليب المناسبة مع الطقل فإنها ستــضـن تثربه للأسس الأولية اللازمة لنمو القيم الاقتصادية لديه وستضمن ممارســته

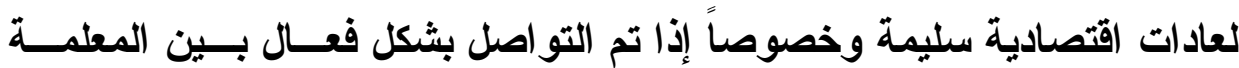

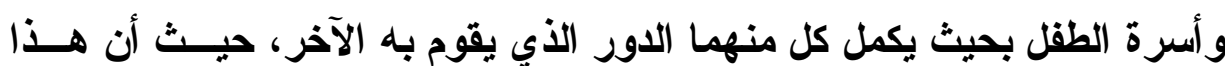

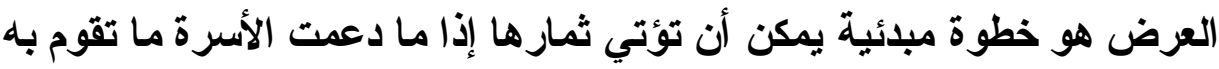


المعلمة من محاولات لإكساب الطقل السلوكيات السليمة التي تمثل البذور الأولى لنمو القيم الاقتصادية بشكلٍ صحيحِ لايه.

وأن استخذام الأشثطة الفنية التي تتناول المفاهيم والـسلوكيات و القـيم

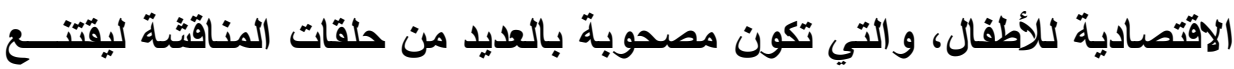
الأطفال بأهمية تلك السلوكيات وهو ما روعي في البرنامج المقترح، حيث تعد الأنثطة الفنية التي يثارك فيها الطقل بتلقائية وبصورة ممتعة ومرحة تزيـــ من قدرته على اكتساب سلوكيات القيم الاقتــصادية الـسليمة والإبتعـاد عـن العادات السلوكية غير السليمة.

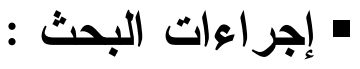

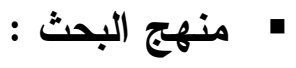

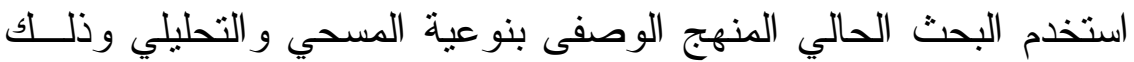

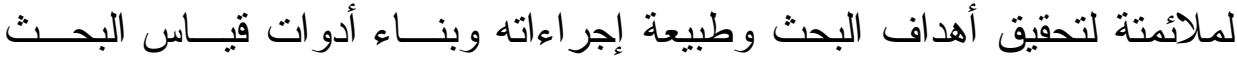

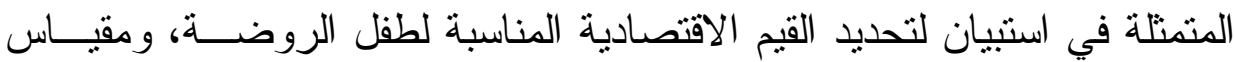

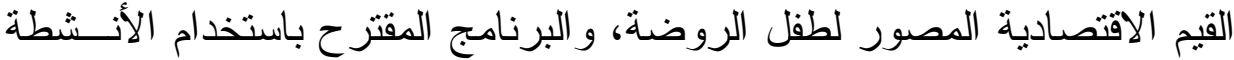
الفنية.

وكذللك تم استخدام المنهج التجريبي الذي يعتمد على اســتخدام التـصميم التجريبي لمجمو عتين Two group design إحداهما تجريبية ويطبـق عليهــا البرنامج المقترح القائم على الأنشطة الفنية لتنمية القيم الاقتصادية لطفل الروضة الفئ

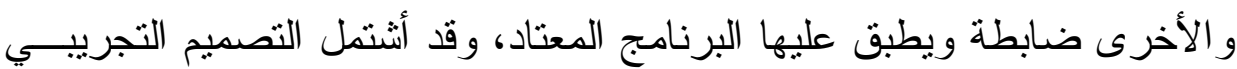
على المتغير ات التالية : 
1- المتغير المستقل : البرنامج القائم على الأنشطة الفنية.

r- المتغير التابع : القيم الاقتصادية المتمثلة في : (قيمة ترشيد الاستهلالك،

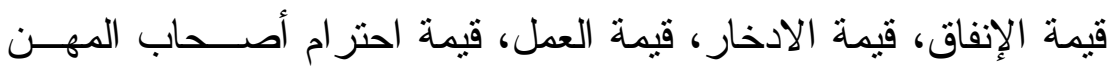

$$
\text { وتقدير هم). }
$$

وفيما يلي شكل (1) يوضح التصميم التجريبي للمجمو عتين (الـضابطة و التجريبية).

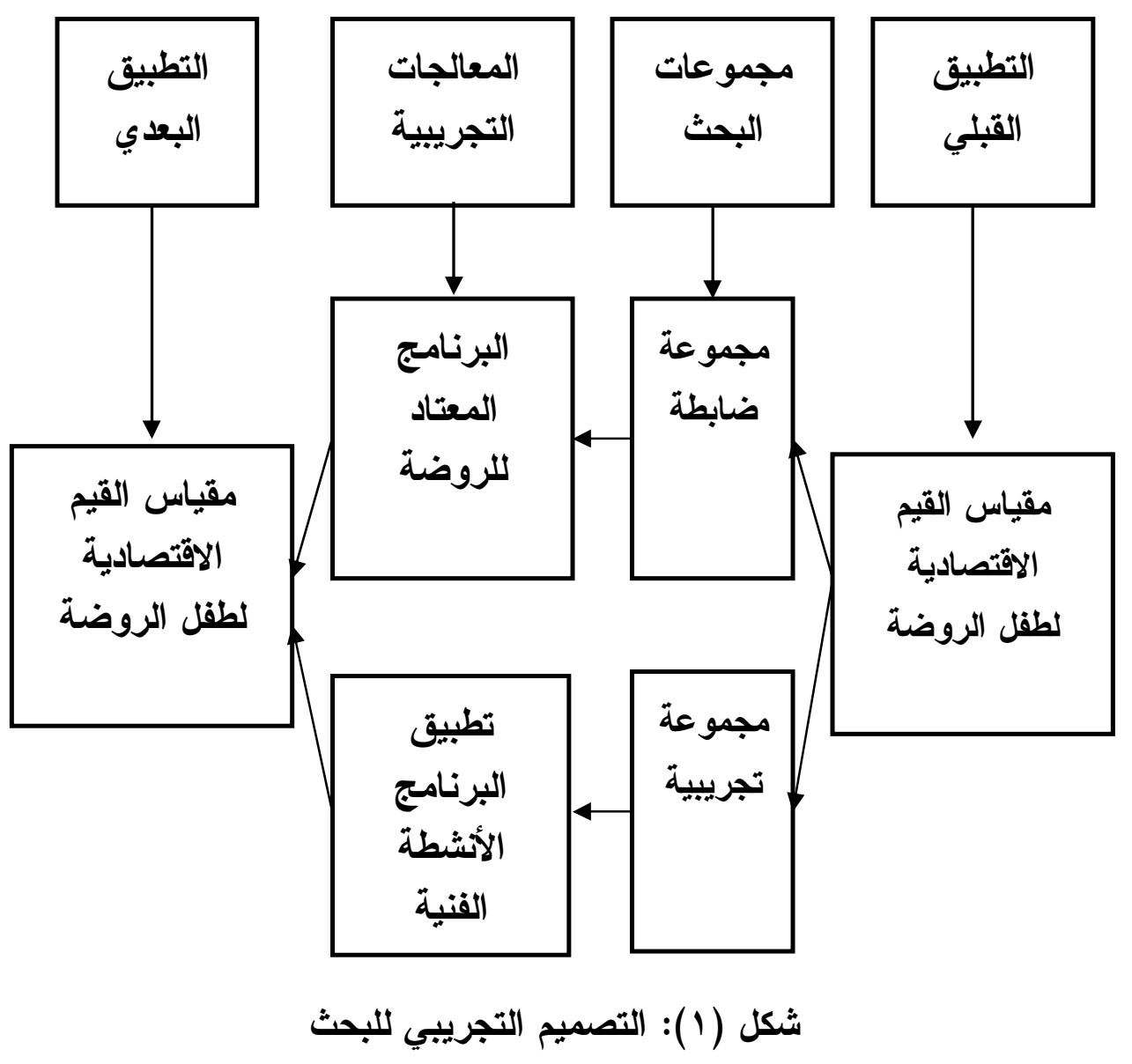




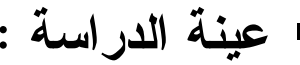

تتز اوح أعمار هم ما بين (-7-7) سنو ات، بمدينــة المنــصورة و التابعــة

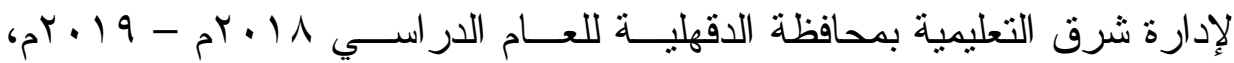

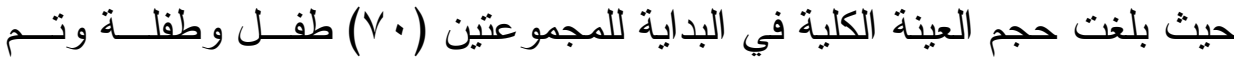
استبعاد (· () أطفال غير ملتزمين في الحضور ليصبح حجم العينة الكلية (·7)

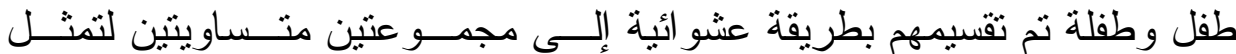
أحدهما المجموعة التجرييية وبلغت (•r) طفل وطفلة ويطبق عليهــا البرنــامج

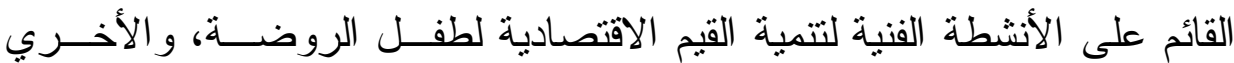

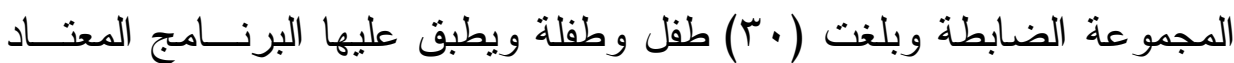

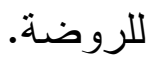

\section{- ت تكافؤ عينة الاراسة :}

تم التحقق من تكافؤ المجمو عتنين التجريبية و الــضـابطة علــى مقيــاس

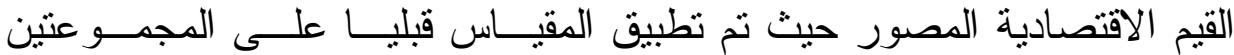

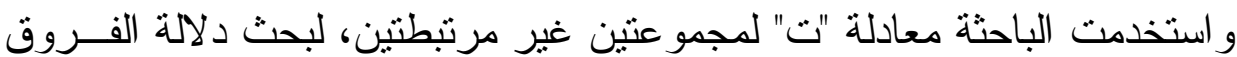

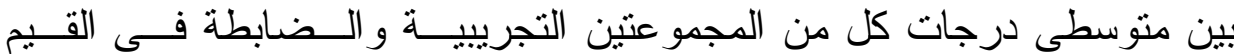

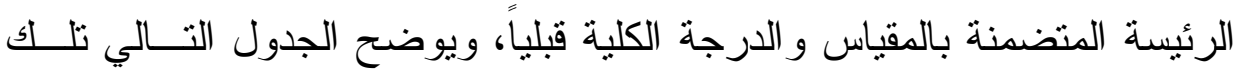
النتائج : 


\section{جدول (1) - (2)}

قيمة "ت" ودلاتها الإحصائية للفروق بين متوسطى درجات كل

من المجموعتين التجريبية والضابطة في درجات مقياس القيم الاقتصادية المصور و الدرجة الكلية قبلياً

\begin{tabular}{|c|c|c|c|c|c|c|c|c|}
\hline مستوى الدلالة & الالالة & قيم ت & الحرية & الآحر اف المياري & المتوسط & العدد & المجموعة & الاقتيمادية المتضمنة القيم \\
\hline \multirow{2}{*}{ غير دالة } & $\cdot, \vee \vee \neg \wedge$ & $\cdot, r q \vee$ & 01 & $1, r r$ & $7, r V$ & $r$. & تجرييية & \multirow{2}{*}{ ترشيد الاستهلاك } \\
\hline & & & & 1, & $7, r V$ & $r$. & ضابطة & \\
\hline \multirow{2}{*}{ غير دالة } & $\cdot, V Y T$ & • ror & $0 \wedge$ & 1,10 & $v, \varepsilon r$ & $r$. & تجرييية & \multirow{2}{*}{ قيمة الإففاق } \\
\hline & & & & $1, \lambda r$ & $V, Y V$ & $r$. & ضابطة & \\
\hline \multirow{2}{*}{ غير دالة } & $\cdot$, , 77 & $\cdot, I V$. & 01 & 1,7 & $\wedge, 1$. & $r$. & تجرييية & \multirow{2}{*}{ قيمة الادخار } \\
\hline & & & & $1, \varepsilon r$ & $\Lambda, \cdot r$ & $r$. & ضابطة & \\
\hline \multirow{2}{*}{ غير دالة } & $\cdot, \vee \vee \subseteq$ & זודות & 01 & $1,7 r$ & $\Lambda, r V$ & $r$. & تجرييية & \multirow{2}{*}{ قيمة العمل } \\
\hline & & & & I, & $\wedge, \perp \vee$ & $r$. & ضابطة & \\
\hline \multirow[b]{2}{*}{ غير دالة } & $\cdot, 7 \wedge \wedge$ & $\cdot, \Sigma \cdot r$ & 01 & I, & $\vee, \wedge$. & $r$. & تجرييية & \multirow{2}{*}{ قأصحاب المهن احترام } \\
\hline & & & & $r,+1$ & $\vee, T$. & $r$. & ضـابطة & \\
\hline \multirow{2}{*}{ غير دالة } & \multirow{2}{*}{$\cdot, 0.9$} & \multirow{2}{*}{ • } & \multirow{2}{*}{$0 \wedge$} & $r, q \vee$ & $r v, q v$ & $r$. & تجريبية & \multirow{2}{*}{ ككل المقياس } \\
\hline & & & & $\varepsilon, r q$ & rr,r & $r$. & ضابطة & \\
\hline
\end{tabular}

يتضح من الجدول عدم وجود فروق ذات دلالة إحصائية بين منوســطى درجات المجموعتين التجريبية و الضابطة في قـيم مقيــاس القـيم الاقتـصـادية المصور وهي : (قيمة ترشيد الاستهلاك، قيمة الإنفاق، قيمسـة الادخــار، قيمـــة العمل، قيمة احتر ام أصحاب المهن وتقدير هم) و الارجة الكلية للمقيــاس؛ حيــث

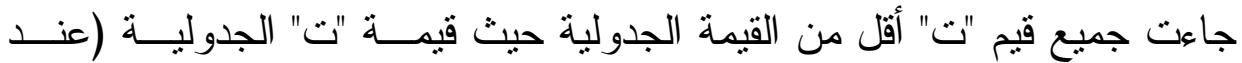


مستوى 0., • •) ودرجات حرية (01)= (1,91) مما يدل على تكافؤ المجمو عتين

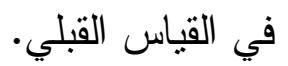

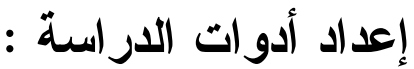

أولا : إعداد الاستبانة تحديد القيم الاقتصادية الملانمة لطفل الروضة :

- تم إعداد الاستبانة في ضوء إطلاع الباحثة علي المر اجع و الدر اسات السابقة

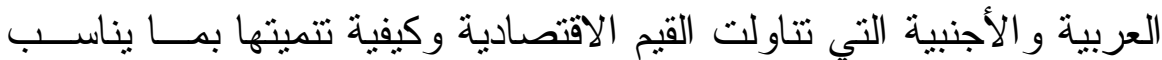

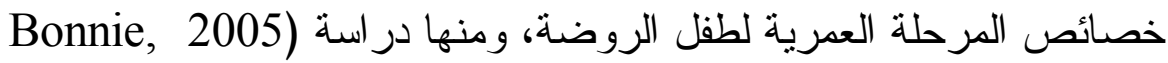
Mary,

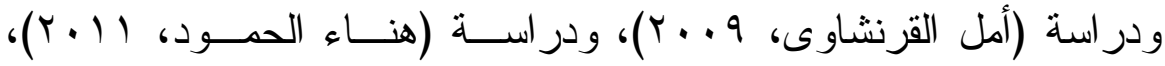

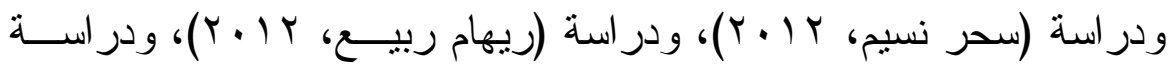

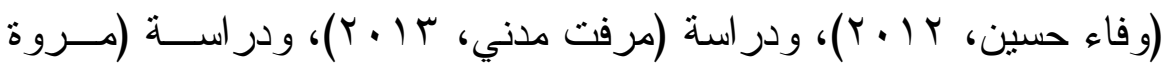

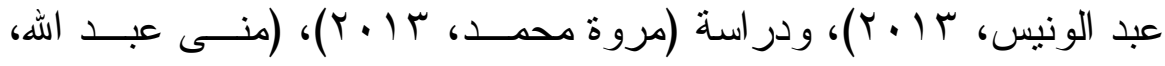

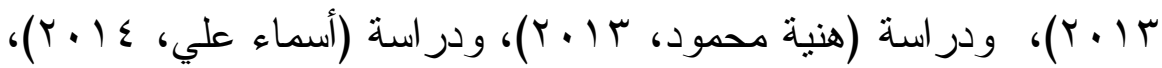

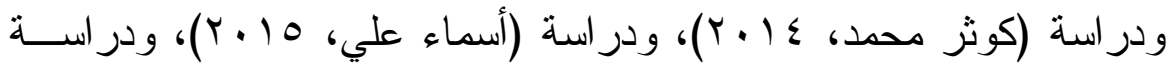

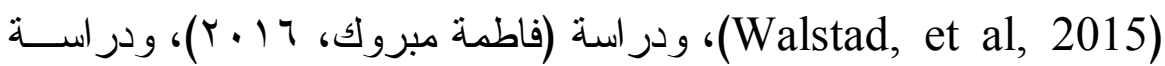

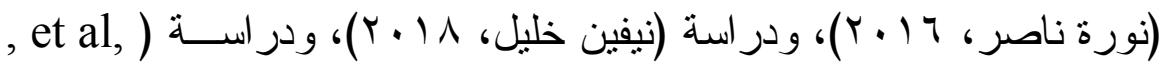

.(Matthias Sutter2018

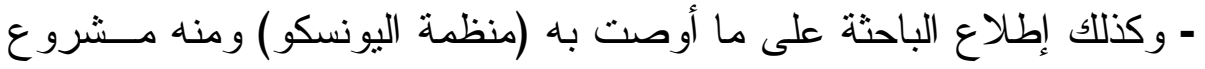

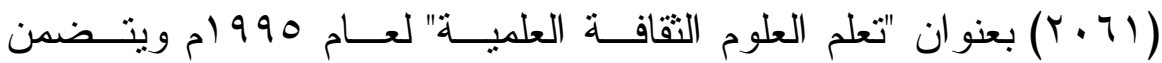
المشروع ثلاث مر احل و الذي يهدف بمرحلته الأولى انه يجب تتمية عادات

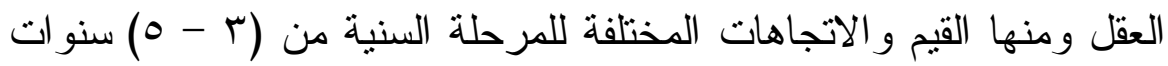


على أن يكون مدعما بالأنشطة المناسبة وبخبر ات التعلم المفتــوح مر اعيــا

$$
\text { أساليب النمو . unesco, 2018). }
$$

وقد تم إعداد قائمة القيم الاقتصادية التي ينبغي تو افرها لدي الأطفال فـي

$$
\begin{aligned}
& \text { شكل استبانة من خلال الخطو ات التالية : } \\
& \text { • تحديد الهوف من الاستبانة : }
\end{aligned}
$$

- وهو التوصل إلى قائمة القيم الاقتصادية وسلوكيتها الفرعيـة المناســبة و الملائمة لطفل الروضة من (0- 7) سنو ات و التي يمكن تتميتها.

\section{إعداد الاستبانة في صورته الأولية :}

في ضوء الخطوات السابقة تم استخلاص بعض القيم الاقتصادية المناسبة لطفل الروضة، حيث تم إعداد الاستبانة في صورتها الأولية متضمنة (^) قـيم اقتصادية رئيسية وهي (قيمة ترشيد الاستهلاك، قيمة الإنفاق، قيمة الإدخار، قيمة

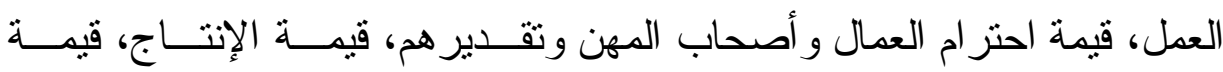
التخطيط، قيمة إعادة التصنيع) يندر ج أسفلهم مجموعة من القيم الفرعية وقد بلغ عددهم (§V) قيمة فرعية. • ضبط استبانة القيم الاقتصادية:

- تم ضبط الاستبانة عن طريق عرضها علـى مجموعــة مــن الـسـادة المحكمين في مجال المناهج وطرق تعلم الطفل للتأكد من : - مدي مناسبة القيم الاقتصادية لطفل الروضة من (0-7) سنو ات. - - التأكد من انتماء عبار ات القيم الفرعية إلى القيمة الرئيسية.

$$
\text { - - مناسبة عبار ات الاستبيان. }
$$


- - إضافة ما يرونه مناسبا لطفل الروضة من القيم الاقتصادية التي يجــب أن تتمي لديه ولم يتضمنها الاستبانة.

وقد تم توزيع الاستبانة على السادة المحكمين متضمن مقياس من ثــلاث مستويات (مناسبة بدرجة كبيرة، مناسبة بدرجة متوسطة، غير مناســب)، وقـــ أجمع الغالبية من السادة المحكمون على حذف ثلاثثة قيم اقتصادية وهـــي (قيمــة الإنتاج، قيمة التخطيط، قيمة إعادة التصنيع) وما يندر ج أسفلها مــن ســلوكيات فر عية لعدم مناسبتها للمرحلة السنية لطفل الروضة من (0-7) سنو ات، وكــللك تعديل صياغة بعض العبار ات التي تصف القيم لغويا للنتابه وقرب المدلول بمــا يتتاسب مع طفل الروضة.

\section{إعداد الاستبانة في صورتها النهائية :}

- في ضوء آر اء السادة المحكمين وما أبدوه من ملاحظات حــول مــدى وضوح عبار ات استبانة القيم الاقتصادية في صورتها النهائيــة ومـــى مناسبتها لطفل الروضة بعد إجر اء الحذف و التعـديلات المتفـق عليهـــا لزيادة الوضوح ولدقة قياس ما وضعت من أجله، فقد تضدنت اســنبانة القيم الاقتصادية في صورتها النهائية (0) قيم اقتصادية رئيسية ينـدرج

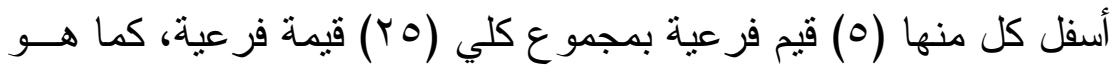
موضح بالجدول التالي : 


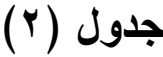

محاور استبانة القيم الاقتصادية الرئيسية والفرعية المناسبة لطقل الروضة

\begin{tabular}{|c|c|}
\hline عدد القيم الفرعية & 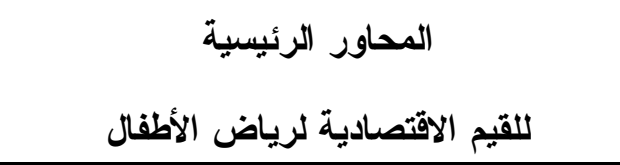 \\
\hline (0) قيم اقتصادية & أولا : قيمة ترشيد الاستهلاك \\
\hline (•) قيم اقتصادية & ثناتيا : قيمة الإففاق \\
\hline (•) قيم اقتصادية & ثنالثا : قيمة الادخار \\
\hline (0) قيم اقتصادية & رابعا : قيمة العمل \\
\hline (•) قيم اقتصادية & خامسا : قيمة احترام أصحاب المهن وتقليرهم \\
\hline (r ) قيمة اقتصادية & 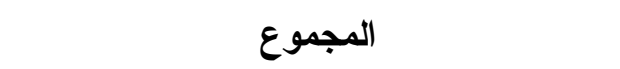 \\
\hline
\end{tabular}

ثانيا : إعداد مقياس القيم الاقتصادية المصور لطقل الروضة. • تحديد مصادر اثتثاق القيم الاقتصادية المصور:

تم إعداد مقياس القيم الاقتصادية في ضوء إطلاع الباحثة علي المراجـع و الدر اسات السابقة العربية و الأجنبية التي نتاولت القيم الاقتصادية وكيفية تتميتها

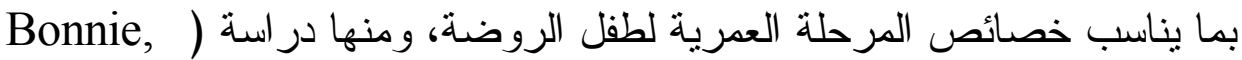

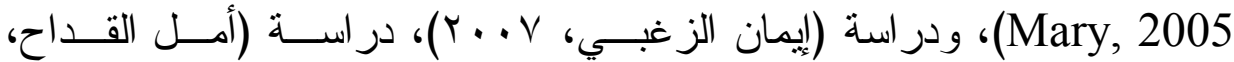

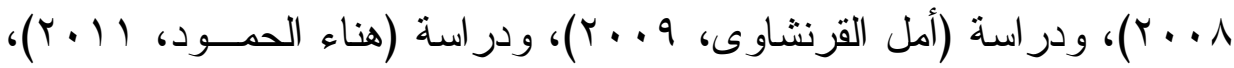

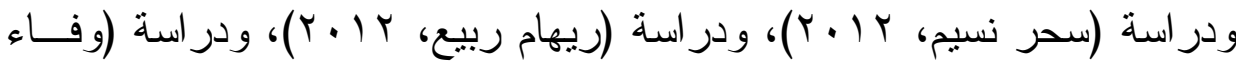

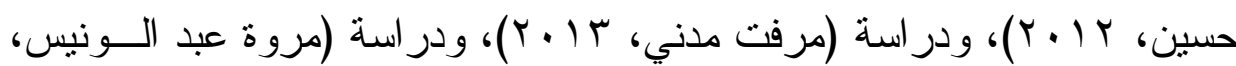




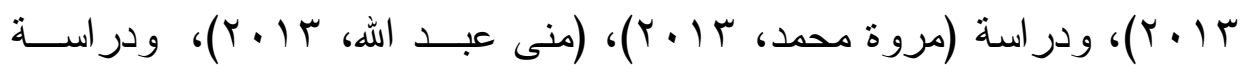

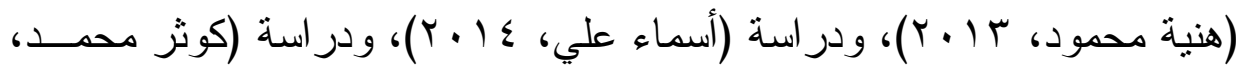

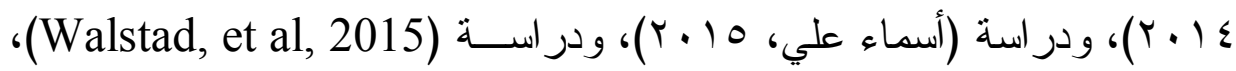

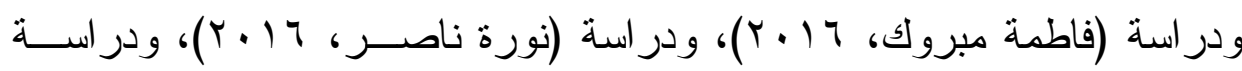

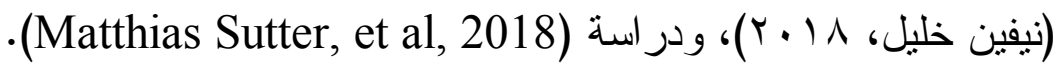
• تحديد الهذف من المقياس المصور للقيم الاقتصادية : - يهدف المقياس إلى التعرف علي مدي استيعاب أطفال الروضة من (-

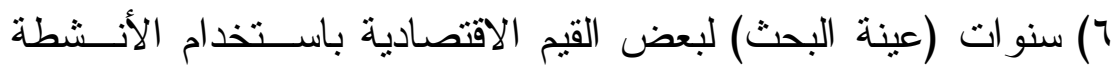

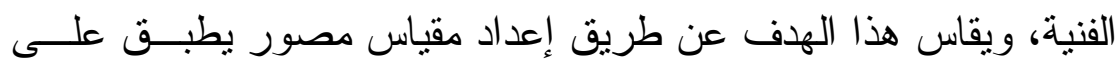

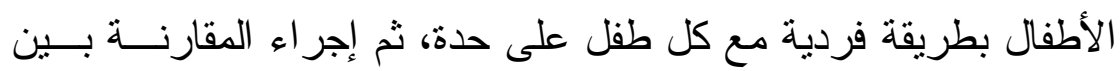
متوسط درجات الأطفال للقياسات القبلية و البعدية. • صياغة مفردات المقياس المصور:

- بعد التوصل للقائمة الرئيسية للقيم الاقتصادية المناسبة لطفل الروضة، تم

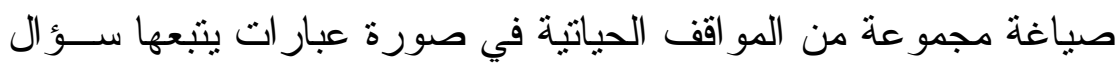

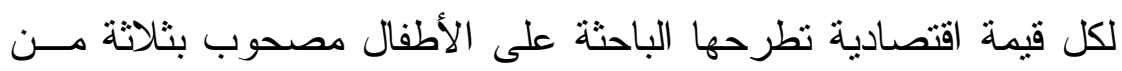
الصور الملونة و التي نتاسب مرحلة رياض الأطفال وتظهر الاستجابات

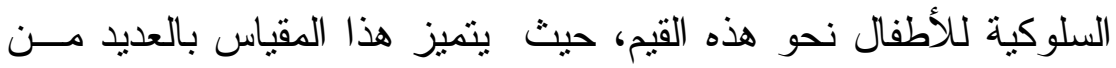

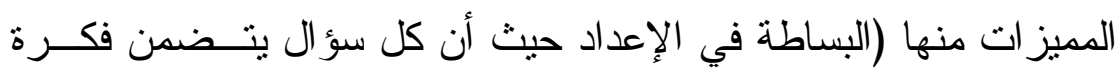
و احدة، وكذلك يسهل تصحيحه في وقت قصير ). 


\section{تعليمات المقياس المصور:}

$$
\text { روعي في صياغة عبار ات المقياس ما يلي : }
$$

ا- يتم كتابة بيانات الطفل على المقياس المصور نظر العدم قدرة الطفل على

$$
\text { القر اعة و الكتابة. }
$$

ץ- أن يكون مرتبط بالقيم الاقتصـادية التي يسعى البرنامج تتميتها لدي طفـلـ

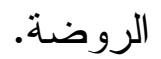

ب- يطبق المقياس بطريقة فردية مع كل طفل على حدة و احد تلو الآخر، ثـــ تقوم بتسجيل إجابات الأطفال وتفريغها فيما بعد.

ع- أن نكون العبار ات و اضحة، ومحددة ومصاغة بلغة عامية بسيطة مناسبة لمستوي الطفل مما ييسر لله فهها، حيث ينم قر اعة المقياس شفويا وباللغة

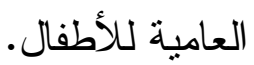

ه- أن تكون الصورة و اضحة ومعبرة حتى يسهل على الطفل فهمها. צ- بشتمل كل سؤ ال علي موقف مصور منضمنا سلوكيات ايجابية وأخــري سلبية منباينة في درجة صحتها.

V- وتقوم الباحثة بسرد الموقف المدعم بالصور علي الطفل وكــذلك ســرد الاستجابات السلوكية الثناثة المصورة المقدمة إليه شفهيا و التي وتتفــاوت الاستجابات السلوكية من حيث درجة صحتها إلـى (اســتجابة ســلوكية صحيحة - استجابة سلوكية محايدة - استجابة سلوكية خاطئة)، ويقوم كل طفل علي حدة باختيار إجابة و احدة سو اء كان ذلك بوضع إصبعه علــى الإجابة أو بوضع علامة (ل) أمام الصورة المناسبة بعد سرد الموقف. 


\section{• بناء المقياس المصور:}

عند بناء المقياس المصور للقيم الاقتصادية تم مر اعاة الأتي: 1- أن تستوفي جميع القيم الاقتصادية الرئيسية و القرعية.

$$
\text { r- أن تكون الصورة و اضحة وملونة وجذابة. }
$$

r- اللغة المستخدمة هي اللغة العامية والتي تتاسب طفل الروضة.

$$
\text { ع - مناسبة لأهداف المقياس. }
$$

وقد تم تحديد محاور المقياس، حيث بشتمل المقيــاس المــصور علــي خمسة قيم اقتصادية رئيسية وبكل قيمة من هذه القيم مجموعة من القيم الفرعيــة

$$
\text { : Lo }
$$

- المحور الأول : قيمة ترشيد الاستهلك، ويشتمل هذا المحور علـى (0) مفردات، وتعني حث الطفل على ضرورة التوفير في اســتهلاك المـــواد الضرورية للحياة اليومية، و عدم الإسر اف في استخدامها بل اســتخدامها استخداما يحافظ على وجودها أطول مدة زمنية ممكنة من (ماء، و غذاء،

$$
\text { وكهرباء، وورق). }
$$

- المحور الثاني: قيمة الإففاق، ويشتمل هذا المحور على (0) مفــردات،

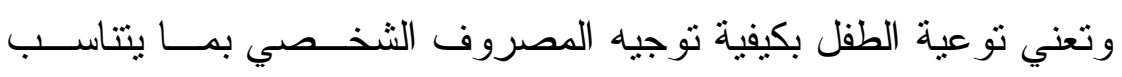
و الموارد التي تأتيه و الحاجات الأساسية، وتعريفة بأساليب إنفاق المــال بشكل مبسط عن طريق ربطها بمصلحته الشخصية (طعـام، ملابـس،

$$
\text { ألعاب، هد ايا). }
$$


- - المحور الثالث : قيمة الادخار، ويشتمل هذا المحور على (0) مفردات،

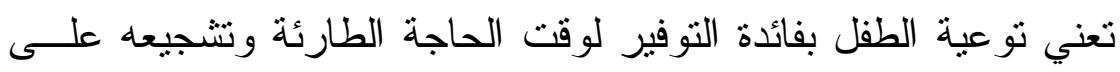

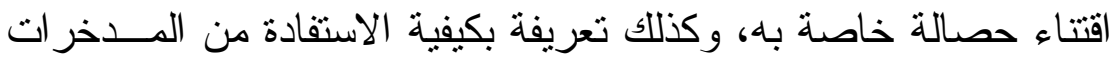

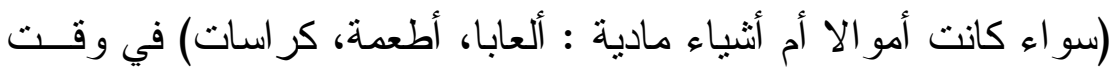
لاحق.

- المحور الرابع : قيمة العمل، ويشتمل هذا المحور على (0) دفــردات،

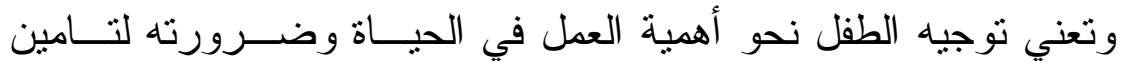

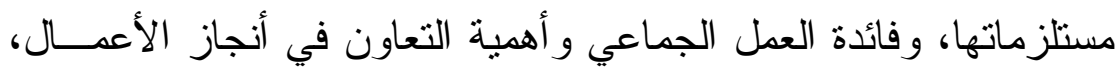

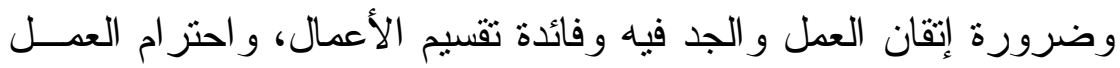
اليدوي، ومر اعاة قو اعد السلامة في أثناء أداء عمل معين.

- المحور الخامس : قيمة احترام أصحاب المهن وتقديرهم، ويشتمل هـــا

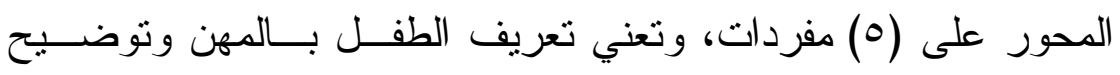

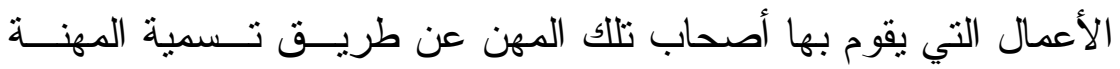

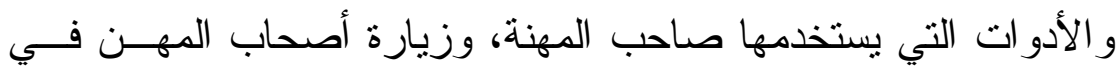

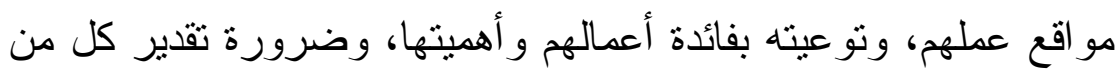

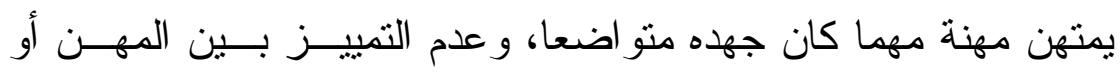
احتقار بعضها في إطار التكامل فيما بينها.

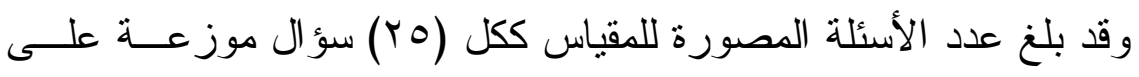

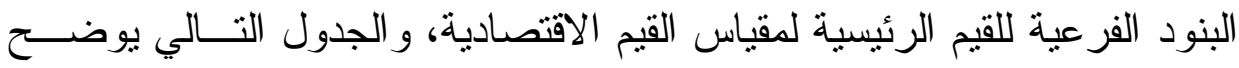
ذلك : 
جدول (r)

مفردات مقياس القيم الاقتصادية لطقل الروضة

\begin{tabular}{|c|c|c|}
\hline عدد الأسئلة & أرقام الأسئلة & القيمة \\
\hline$\bullet$ & $0-\varepsilon-r-r-1$ & أولا : قيمة ترشيد الاستهلاك \\
\hline$\bullet$ & $1 \cdot-9-1-v-7$ & ثانيا : قيمة الإنفاق \\
\hline 0 & $10-1 \leq-1 r-1 r-11$ & ثالثا : قيمة الادخار \\
\hline ○ & $r \cdot-19-11-1 v-19$ & رابعا : قيمة العمل \\
\hline 0 & $r \Delta-r \leq-r r-r r-r 1$ & خامسا : قيمة احتر ام أصحاب المهن \\
\hline 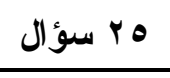 & & 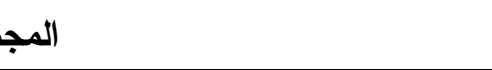 \\
\hline
\end{tabular}

تقدير درجات المقياس المصور:

- - يتفاوت استجابات الأطفال السلوكية للقيمة الاقتصادية من حيث درجــة صحتها ما بين (استجابة سلوكية صحيحة - استجابة سلوكية محايــدة-

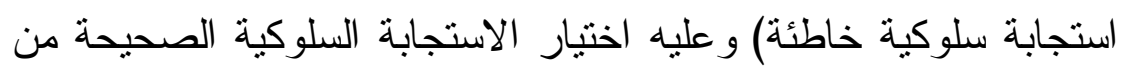

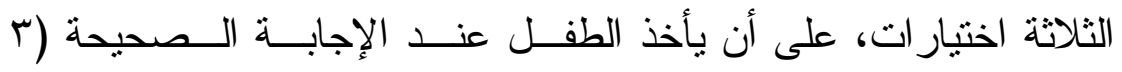

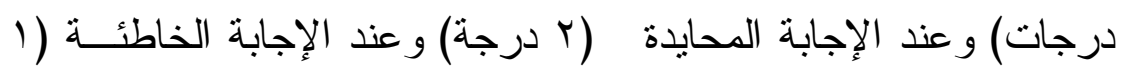
درجة).

- ويتم تقدير درجات المقياس بناء علــي اســتجابات الأطفــال المـسجلة للخمسة محاور للقيم الاقتصادية الرئيسية والتي تتدرج أسفلها (0) قـئم

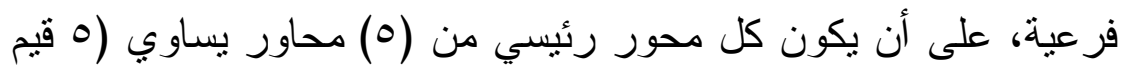

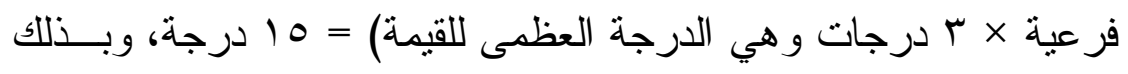


يكون الدرجة الكلية للمقياس هي (10) درجة للمحور الرئيسي الواحد × (0) محاور رئيسية = V V درجة للمقياس ككل.

• المعاملات العلمية لمقياس القيم الاقتصادية (معامل الصدق والثبات) :

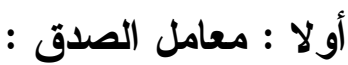

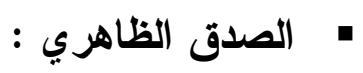

يعرف الصدق بأنه الاختبار الذي يقيس ما أعد من أجل قياسية فعـلا، أي يقيس الوظيفة التي اعد لقياسها، و لا يقيس شيئا مختلفا، والصدق في هذا الإطار

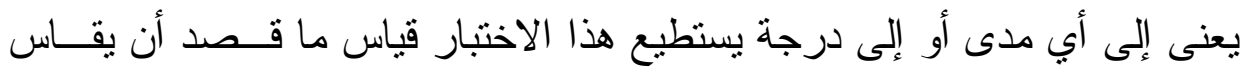

وللتحقق من صدق مقياس القيم الاقتصـادية، ومدي مناسـبته للأغــر اض

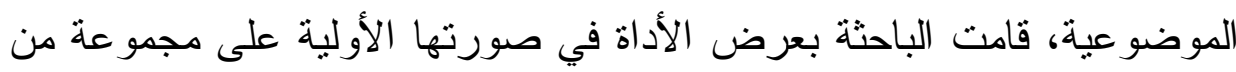

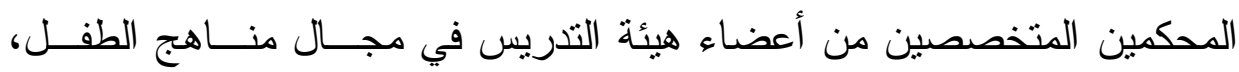
و العلوم النفسية للطفل بهدف التحقق من الصدق الظاهري للمقياس من حيث : - مدي وضح تعليمات المقياس. - مدي ملائمة ووضوح الصور في المقياس. - مدي ملاءمة أسئلة المقياس المصور لمرحلة رياض الأطفــال (أطفــال المستوي الثاني).

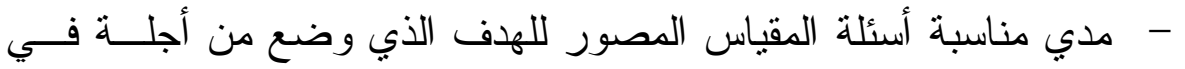
تتمية القيم الاقتصادية، و انتماء الأسئلة للمحور الذي ينتمي إليه. - مدي سلامة الصياغة اللغوية و العلمية لأسئلة المقياس. 
- مدي ملائمة التدرج الثلاثي لمقياس ليكرت الذي يحدد استجابات عينــة

$$
\text { الدر اسة. }
$$

- - تقديم أي مقترحات أو تعديلات من شأنها أن تثري أداة الدراسة من أجل الوصل إلى الصورة صادقة للمقياس.

وقد أبدى المحكمون آراءهم حول مــدى وضـــوح المقيــاس المــصور

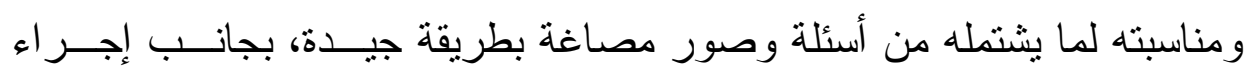
بعض التعديلات المطلوبة وكان من أهمها :

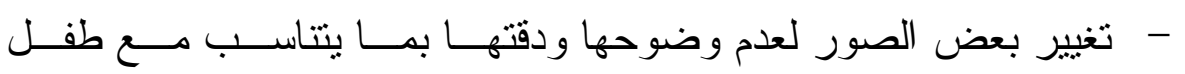
الروضة. - - ضرورة طبع المقياس بالألو ان لسهولة رؤية الصور . - مر اجعة بعض الصياغات اللغوية لبعض المفردات. • صدق الاتساق الداخلي أو التجانس الـــاخلي لمفـردات مقيــاس القـيم الاقتصادية المصور :

بعد التأكد من الصدق الظاهري لمقياس القيم الاقتصادية عـن طريــق

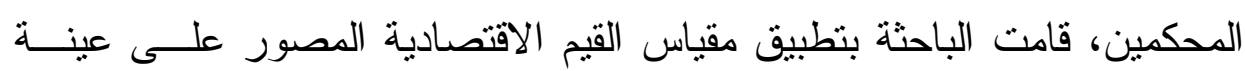

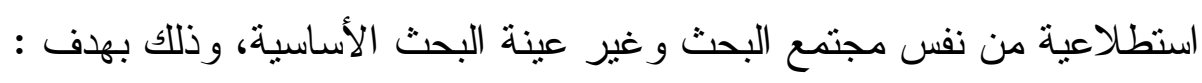

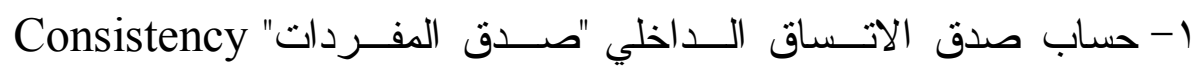
Internal لمقياس القيم الاقتصادية. r- حساب ثبات مقياس القيم الاقتصادية . r- حساب درجة الو اقعية . 


$$
\begin{aligned}
& \text { ع- حساب زمن مقياس القيم الاقتصادية . } \\
& \text { وفيما يلي تفصيل ذلك : }
\end{aligned}
$$

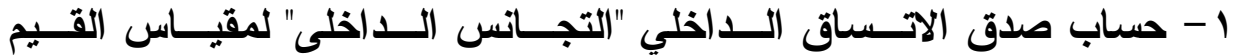

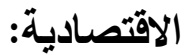

تعتمد هذه الطريقة على مدى ارتباط كل مفردة من مفردات المقياس مع المحور الخاص به، وكذللك ارتباط كل مفردة من مفــردات المقيــاس بعـضهـا

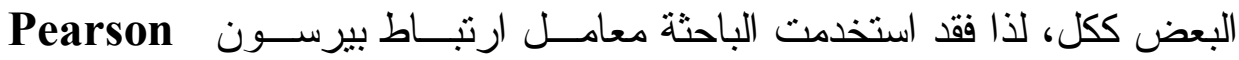
Coefficient الدرجة الكلية لكل قيمة، كما هو موضح بالجدول التالي :

$$
\text { جدول (飞 ) }
$$

\begin{tabular}{|c|c|c|c|c|c|c|}
\hline 0 & $\varepsilon$ & $r$ & r & 1 & العبارة & \multirow{2}{*}{ ترشيد الاستهلاك } \\
\hline$* *, \vee \vee 9 \wedge$ & $* *, \Lambda) r$ & $* *, \vee v)$. & $* *, \vee \vee \vee O$ & $* *, \vee \vee q r$ & معامل الارتباط & \\
\hline 1. & 9 & $\wedge$ & v & 7 & العبارة & \multirow{2}{*}{ قيمة الإخفاق } \\
\hline$* *, \wedge, V$ & $* *, \vee \vee \vee 0$ & $* *, 0 \vee \varepsilon$ & $* *, \vee \leq \leq 0$ & $* *, V \leq \varepsilon$ & معامل الارتباط & \\
\hline 10 & $1 \leq$ & ir & ir & 11 & العبارة & \multirow{2}{*}{ قيمة الإدخار } \\
\hline$* *, \vee \cdot O$ & $* *, V \times T$ & $* *, \vee \vee T Y$ & $* *, 9.9$ & $* *, 0 \mathrm{VV}$ & معامل الارتباط & \\
\hline r. & 19 & 11 & iv & 17 & العبارة & \multirow{2}{*}{ قيمة العمل } \\
\hline$* *, \wedge 9 r$ & $* *, \wedge \leq \varepsilon$ & $* *, 9.7$ & $* *, \wedge r \varepsilon$ & $* *, 0 \leqslant V$ & معامل الارتباط & \\
\hline ro & $r \varepsilon$ & rr & rr & r & العبارة & \multirow{2}{*}{ قيمة احترام أصحاب } \\
\hline$* *, \nearrow, \Lambda$ & $* *, 707$ & $* *, \vee \wedge \varepsilon$ & $* *, \vee \backslash V$ & $* *, T r$. & معامل الارتباط & \\
\hline
\end{tabular}

معاملات الارتباط بين درجة كل مفردة من مفردات مقياس القيم الاقتصادية مع الدرجة الكلية لكل قيمة التى تنتمي إليها

(**) دال عند ا •,., 
من خلال النتائج التي أسفرت عنها معاملات الارتباط، يتضح أن جميـع معاملات الارثباط تتر اوح بين (0 . V, •، 7 ـ 9, • ) وهى جميعاً دالة عند مستوى 1 •, •، وبالتالي فإن عبار ات مقياس القيم الاقتصادية تتجه لقياس درجة كل قيمة من القيم الرئيسة للمقياس المصور.

ولتحديد مدى اتساق درجات القيم الرئيسة، و الدرجة الكلية للمقيــاس، تـــ حساب معاملات الارتباط بين درجة كل قيمة رئيسى، و الدرجة الكلية للمقيــاس، ويوضح الجدول التالي قيم معاملات الارتباط بين درجة كـلـل قيمـة رئيـسىى، و الدرجة الكلية للمقياس :

\section{(0) (0دول}

معاملات الارتباط بين درجة كل قيمة رئيسة مع الدرجة الكلية للمقياس

\begin{tabular}{|c|c|c|}
\hline مستوى الدلاية & معامل الارتباط بالنسبة & القيم المتضمنة بالمقياس \\
\hline$\cdot, \cdot 1$ & **, Arr & ترشيد الاستهلاك \\
\hline$\cdot, \cdot 1$ & $* *, 700$ & قيمة الإخفاق \\
\hline$\cdot, \cdot 1$ & $* *, \wedge 11$ & قيمة الادخار \\
\hline$\cdot, \cdot 1$ & $* *, r \leq r$ & قيمة العمل \\
\hline$\cdot, \cdot 1$ & $* *, 7 \wedge 9$ & قيمة احترام أصحاب المهن وتقديرهم \\
\hline
\end{tabular}

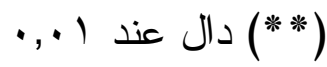

من خلال النتائج التي أسفرت عنها معاملات الارتباط، يتضح أنها جميعاً

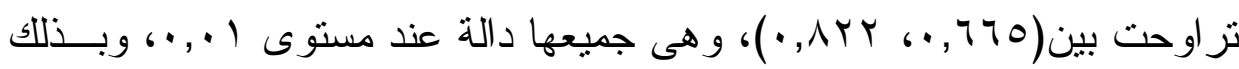
يكون مقياس القيم الاقتصادية مُناسباً للتطبيق على مجموعة البحث الأساسية. 
r - حساب الثبات لمقياس القيم الاقتصادية:

يُقصد بثبات مقياس القيم الاقتصادية أن يُعطى مقياس القـيم الاقتـ صـادية

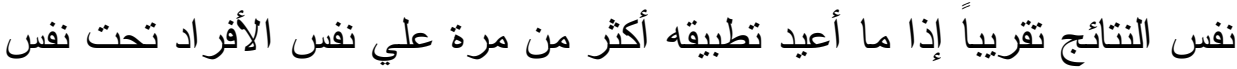

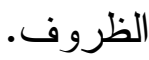

و هناك عدد من الطرق الإحصائية لقياس الثبات ومــن أكثرهــــــــــا

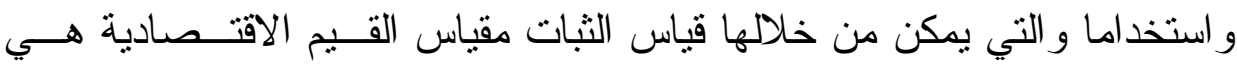
طريقة ألفا كرونباخ Crunbach Alpha، و التي تعتمد على الاتساق الداخلي

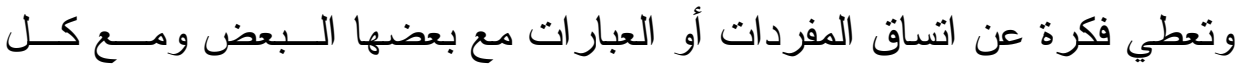
مفردات أو عبارة بصفة عامة ككل، وتعتمد طريقة الفا كرونباخ على التجزئــة أكثر من جزء وبشكل متكرر وقياس الارتباطات بين تلك الأجز اء بدلا من قياس الارتباط بين نصفين فقط كما هو الحال في ارتباط بيرسون أو سبيرمان، وبشكل

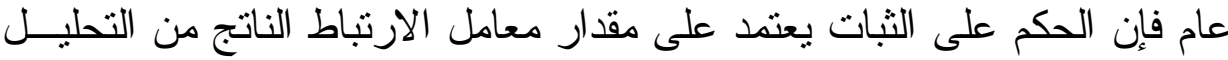
الإحصائي، وكثير من الباحثين يعتبرون أن معامل الارتباط الذي يتجاوز • •, •.

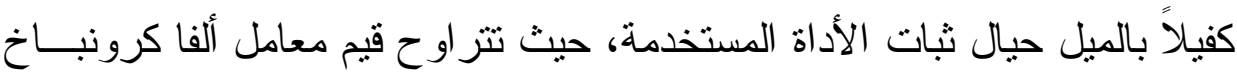

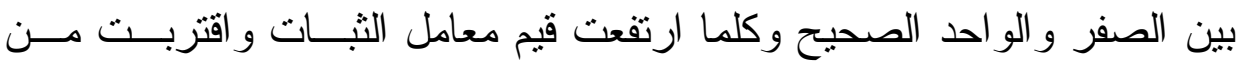
الو احد الصحيح دل ذلك على زيادة الثبات في البيانات.

ولضمان تحقيق ثبات المقياس و التحقق من دقته و اتساقة قامــت الباحثَــة

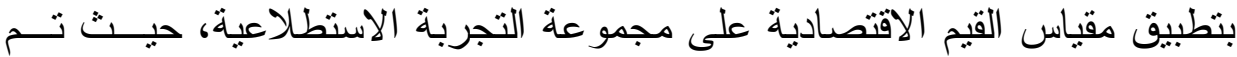

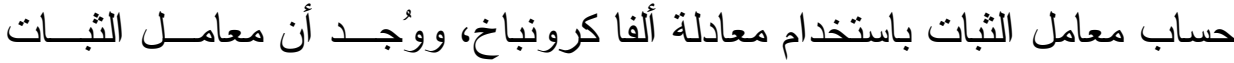
للمقياس ككل كما يحددها تطبيق المعادلة على النحو الـــى يوضــــه الجــول

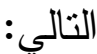




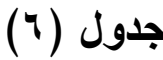

معامل ثبات (ألفا كرونباخ) لمقياس القيم الاقتصادية المصور

\begin{tabular}{|c|c|c|c|c|c|}
\hline معامل ثبات & التباين & الانحر اف & المتوسط & العدد العد & القيم المتضمنة \\
\hline$\cdot, \wedge r q$ & 9,94 & $r, 10$ & $I T, \cdot V$ & 0 & ترشيد الاستهلك \\
\hline$\cdot, \vee \vee \vee$ & $9,7 \leqslant$ & $r, 1$. & 11,14 & 。 & قيمة الإخفاق \\
\hline$\cdot, \nabla \vee r$ & $9, Y r$ & $r, \cdot \varepsilon$ & 11,0 & 0 & قيمة الادخار \\
\hline$\cdot, \wedge \vee$. & $M_{, \cdot T}$ & $r, \Sigma V$ & $11, r v$ & 0 & قيمة العمل \\
\hline$\cdot, V_{1}$ & $q, \cdot \vee$ & $r, \cdot 1$ & $1 \cdot, 9 V$ & 0 & قيمة احتر ام أصحاب \\
\hline$\cdot, 9 \cdot \varepsilon$ & Irv, vq & $11, v \leq$ & 04,94 & ro & المقياس ككل \\
\hline
\end{tabular}

يتضح من الجدول أن قيمة معامل الثبات لأبعاد مقياس القيم الاقته صادية

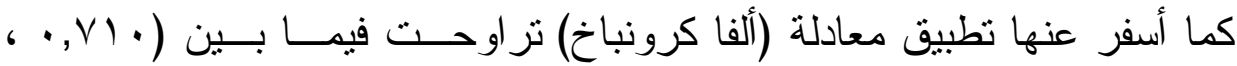

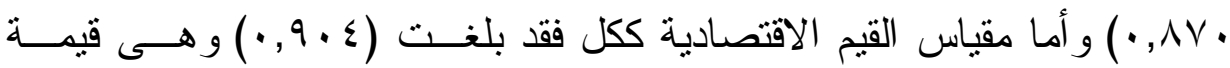
مرتفعة، و هذا يُعد ثبات مقياس القيم الاقتصادية قبد البحث. r- حساب درجة واقعية عبار ات مقياس القيم الاقتصادية : تحدد درجة الو اقعية للعبار ات بمدى تطابق الموقف المثير مــع الموقـف الذى يعيشه الطفل؛ مما يساعد على اختبار إحدى الاستجابات المتطرفة؛ فيـشير إلي التعبير عن صدق الاتجاه، وتستخدم معادلة هوفستاتر Hofstaetter لقياس مدى و اقعية العبارة الخاصة بمقياس القيم الاقتصادية . مدى و اقعية العبارة = الجذر التربيعي ((مج سب) + (مج س -)) / (مج س •)). (مج س +) = مجموع استجابات مو افق 


$$
\text { (مج س س - ) = مجموع استجابات غير مو افق ع مجن استجابات غير متأكد }
$$

وقد جاءت درجة الو اقعية لجميع عبار ات مقياس القيم الاقتصادية أكبــر

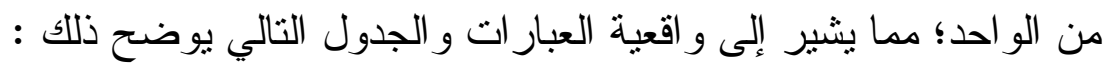

$$
\text { جدول (v) }
$$

\begin{tabular}{|c|c|c|c|c|c|}
\hline 0 & $\varepsilon$ & $r$ & r & 1 & العبارة \\
\hline r & $r, r$ & r & $r, \Lambda$ & س & درجة الو اقعية \\
\hline 1. & 9 & $\wedge$ & v & 7 & العبارة \\
\hline r r & r, r & $1, r$ & r, r & 7,7 & درجة الو اقعية \\
\hline 10 & $1 \varepsilon$ & ir & Ir & 11 & العبارة \\
\hline$r, v$ & r & $r, r$ & r, r & r, r & درجة الو اقعية \\
\hline$r$ & 19 & 11 & 18 & 17 & العبارة \\
\hline r, r & $r, 0$ & r & $r, v$ & r, r & درجة الو اقعية \\
\hline ro & $r \leq$ & $r r$ & $r r$ & r & العبارة \\
\hline r, & $1, \wedge$ & $r, \Lambda$ & $r, r$ & r & درجة الواقعية \\
\hline
\end{tabular}

درجة الو اقعية لكل عبارة بمقياس القيم الاقتصادية

\begin{tabular}{|c|c|}
\hline المدي & درجة الو اقعية \\
\hline أقل من 1 & منخفضة \\
\hline$r, \leqslant q-1$ & متوسطة \\
\hline$\varepsilon, 99-r, 0$. & فوق متوسطة \\
\hline $1 .-0$ & مرتفعة \\
\hline أكثز من . 1. & مرتفعة جـا \\
\hline
\end{tabular}

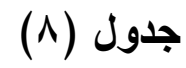

مدي درجات الو اقعية كما حددها هوفستاتر 
يتضح من الجدول أن جميع درجات الو اقعية لكل عبار ات مقياس القـيم

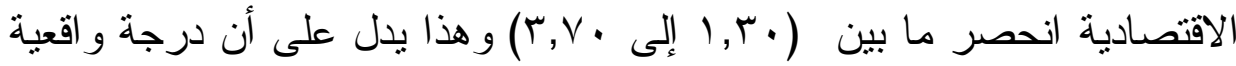

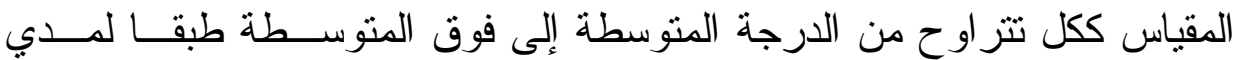
درجات الو اقعية كما حددها هوفستاتر .

ع - تحديد الزمن اللامم لأداء مقياس القيم الاقتصادية :

تم تحديد الزمن الــلازم للإجابـــة عـنـ مقيــاس القـيم الاقتــصـادية؛ بتسجيل الزمن الذي استغرقته كل طفل فى مجموعة البحث الاستطلاعية لإنهــاء

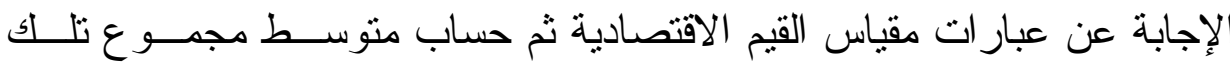

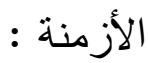
- مجموع الأزمنة = . . م دقيقة . - عدد أفر اد المجموعة الاستطلاعية = •r طفل وطفلة .

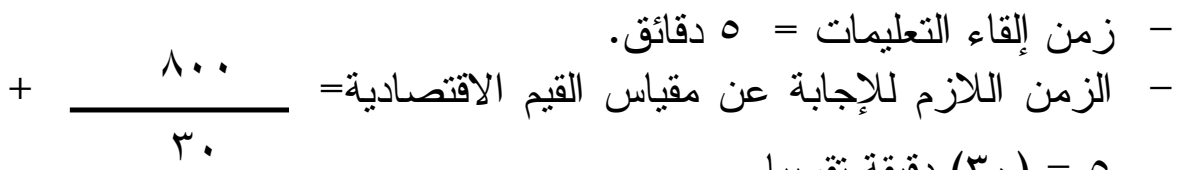
= = (ب) دقيقة تقريبا.

وبهذا يكون الزمن اللازم لتطبيق مقياس القيم الاقتصادية هو (•r) دقيقة

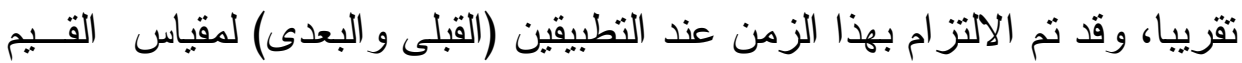
الاقتصادية على مجموعتي البحث الأساسية.

وفي ضوء ما سبق من إجر اءات متبعة و آر اء الـسـادة المحكمـين عـن طريق حذف وتعديل لعبار ات المقياس، وكذلك إجر اء المعاملات العلمية للمقياس

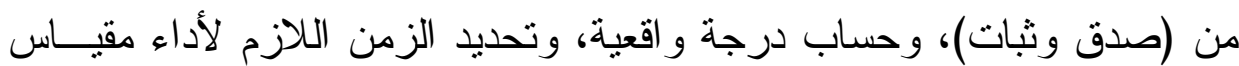


القيم الاقتصادية المصور ، قد أصبح المقياس جاهز فــي صــورنه النهائيــة (")

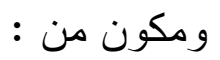

- - صفحة الغلاف : و عليها اسم المقياس وبيانات الطفل.

- - صفحتي التعليمات : وتتنتمل على الهدف من الكقياس وصياغة عبار ات الدقياس ومحاور المقياس وتعليمات المقياس وتقدير درجات المقياس.

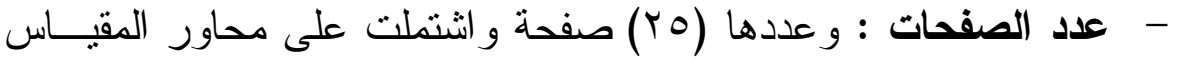
الرئيسية و الفر عية لمقياس القيم الاقتصادية المصورة.

ثالثا : تصميم البرنامج القائم علي الأشظة القنية :

يتتاول هذا الجزء خطو ات بناء وتصميم البرنامج وضــبطه، و أســاليب

تنفيذه وتقويمه، ويمكن توضيح ذللك من خلال الخطو ات الثالية :

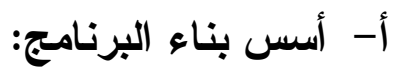

1- مر اعاة خصائص نمو الطفل في هذه المرحلة العمرية، مع الأخذ فـي

$$
\text { الاعتبار بمبدأ الفروق الفردية بينهم. }
$$

r- التأكد على دور الطفل وفاعليته من خلال الأنشطة الفنية التى تعتمــد

$$
\text { على النشاط الذاتي للطفل. }
$$

ب- تدريب الأطفال على السلوكيات الاجتماعية المرغوبــة مـن خــلد

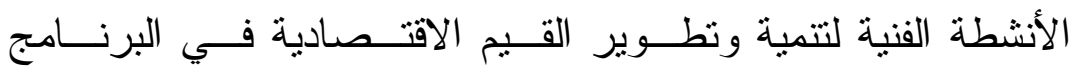

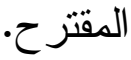

(") ملحق (ץ) مقياس القيم الاقتصادية المصور لطفل الروضة 


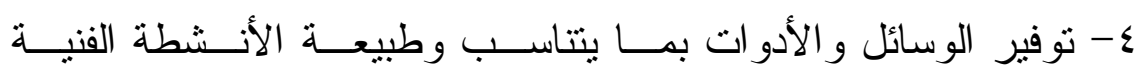

$$
\text { المستخدمة في البرنامج المقترح. }
$$

0 - إناحة الفرصة الكافية للممارسة العملية لجميع الأطفال سو اء بــصورة

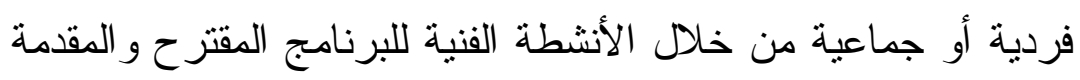

7- مر اعاة استمر ارية وتكر ار القيم الاقتصـادية الفرعية المقدمة للأطفــال

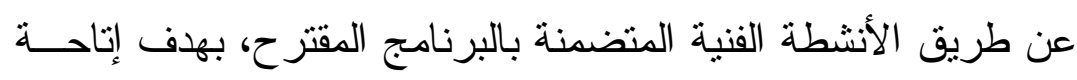
الفرصة للطفل لتوظيف ما تعلمه من قيم في مو اقف مشابهة.

V- استخدام وسائل و أساليب الثقويم المناسبة لقياس نو اتج التعلم بالبرنامج

$$
\text { المقتر ح. }
$$

^- تتوع الأنشطة الفنية بحيث تعمل على مر اعاة الفروق الفردية وتحقيق

$$
\begin{aligned}
& \text { مبدأ تكافؤ الفرص لجميع الأطفال. } \\
& \text { ب-تحديد الإطار العام للبرنامج، ويشمل: } \\
& 1 \text { - أهداف البرنامج : }
\end{aligned}
$$

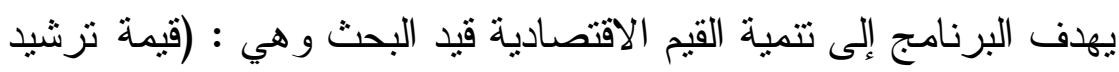

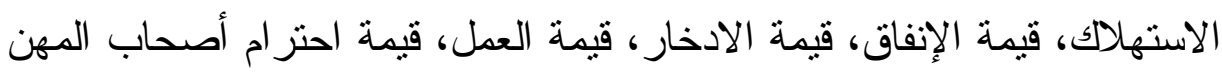

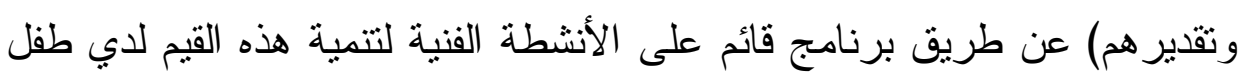
الروضة.

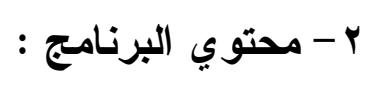

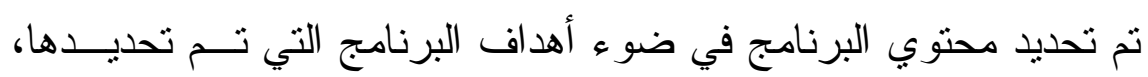

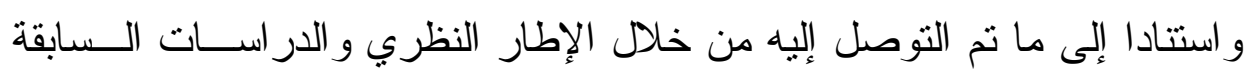


العربية و الأجنبية، وكذلك قائمة القيم الاقتصادية التي تم التوصل إليهــا، وبنــاء

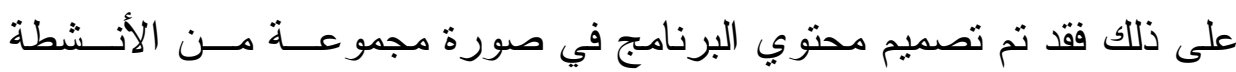
الفنية، و التي تتيح للطفل فرص اكتساب هذه القيم بأسلوب مبسط. ب - الاستر اتيجيات الملانمة للبرنامج:

تستخدم الدراسة الحالية العديد من الاستر اتيجيات التعليمية القائمــة علـى الأنشطة الفنبة وهي: (الرسم - التشكيل - القص و اللصق - الأثــغنال اليدويـــة

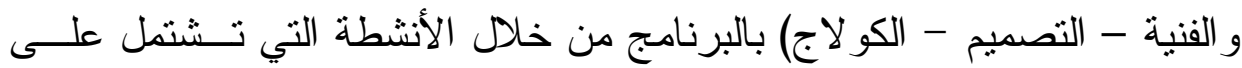
القيم الاقتصادية كأساس لمحتو اه.

\section{؛ - الوسائل و الأدوات المستخدمة في البرنامج المقترح :}

عند إعداد وتصميم البرنامج القائم على الأنــشطة الفنيــة لتتميــة القـيم

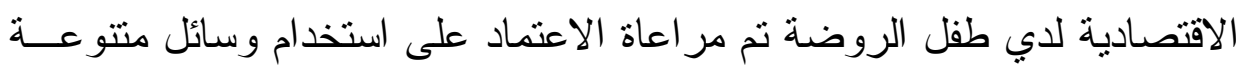

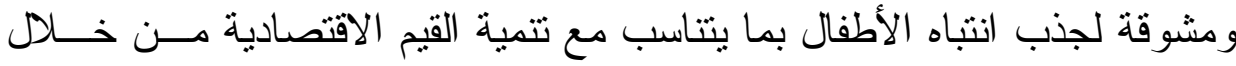

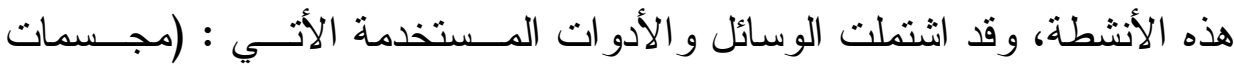

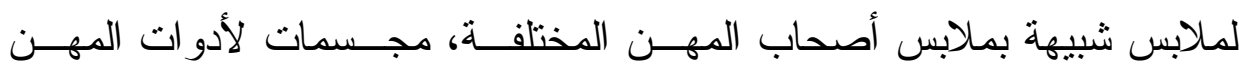

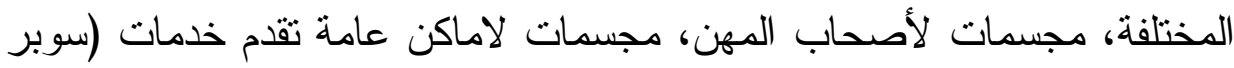

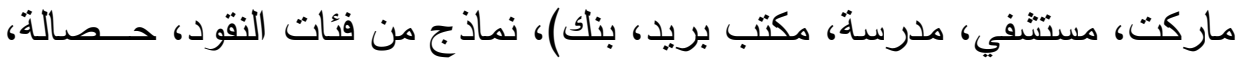

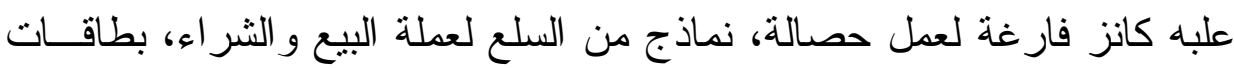

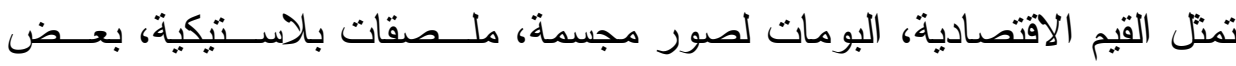

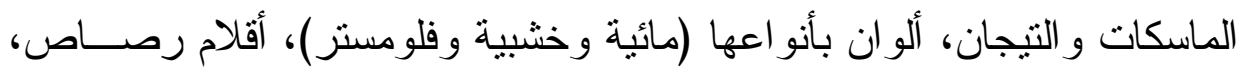

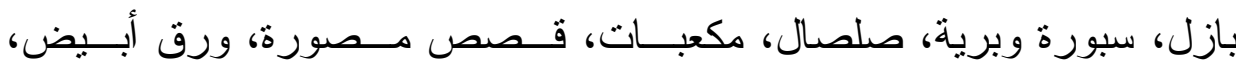
كر اسات رسم، مو اد لاصقة، جهاز كمبيوتر ، داتا شو ... الخ. 


\section{0 - أساليب تقويم البرنامج المقترح :}

تمثلت أساليب التقويم المستخدمة في البرنامج القائم على الأنشطة الفنـــة

$$
\text { لتتمية القيم الاقتصادية فيما يلي: }
$$

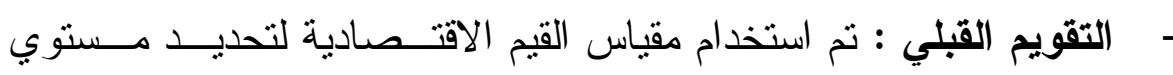

الأطفال (عينة البحث) قبل تطبيق البرنامج المقترح.

- التقويم التكويني : وهو التقويم المستتر منــذ بدايـــة تطبيــق أنــشطة البرنامج على الأطفال وحتى نهايته ويتم من خلال سؤال الأطفال عـدة أسئلة في نهاية كل نشاط من أنشطة البرنامج توضح مدي استفادة الطفل و استيعابه لإجر اءات النشاط المتضدنة ببرنامج الأنشطة الفنية المقترح.

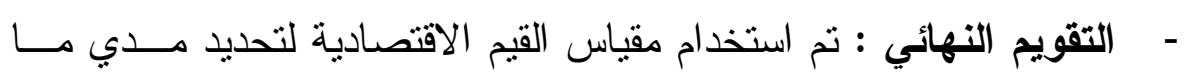
اكتسبه أطفال المجموعة التجريبية من قيم اقتصادية بعد تطبيق البرنامج المقتر ح.

\section{ت - عرض البرنامج المقترح على المحكمين :}

تم عرض البرنامج المقترح في صورته الأوليــة علــى مجموعـــة مــن المحكمين في مناهج وطرق تعليم الطفل، وذللك بهدف التعرف على آرائه حول

- مناسبة البرنامج المقترح لتتمية القيم الاقتصادية لطفل الروضة.

- صحة البرنامج من حيث : الأهداف، عناصر المحتوي، ومدي ملاعمــة المادة العلمية، وكذلك مدي ملائمة الأنشطة المتكاملة التي تحتوي علـى هلى

$$
\text { القيم الاقتصادية، و أيضا وسائل التقويم الموضوعة. }
$$


وقد ابدي السادة المحكمين مو افقتهم على البرنامج ككل بعد إجر اء بعـض

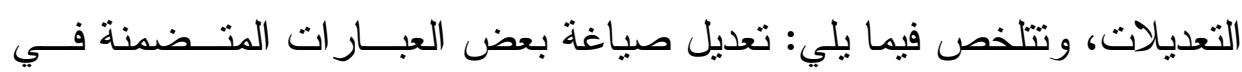

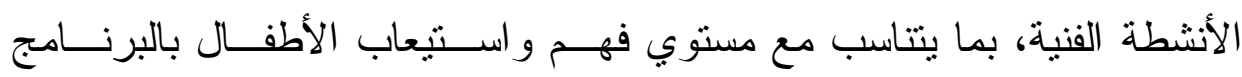

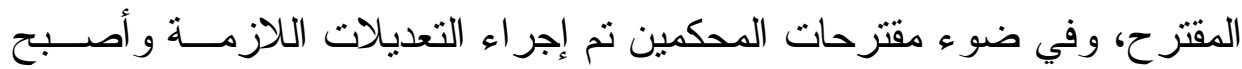
البرنامج في صورته النهائية (") وصالح للنطبيق.

\section{إجراعات تتفيذ التجربة :}

أولا : التطبيق القبلي لأداة البحث :

تم تطبيق الأدوات المستخدمة في البحث و المتمثلة فـي (مقيــاس القـيم الاقتصادية المصور) على عينة البحث المجمــوعتين (التجريييـة و الــضـابطة)

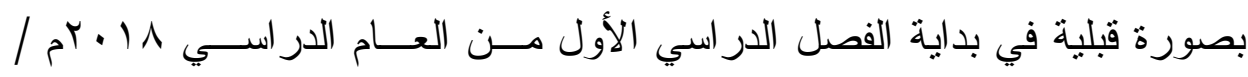

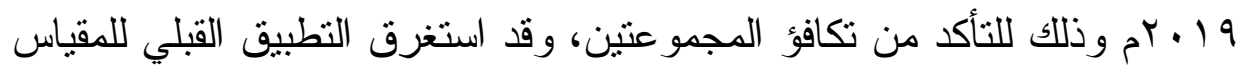

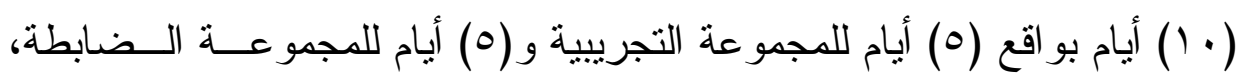
وتم تصحيح الإجابات ورصد الدرجات للقياس القبلي.

\section{ثانيا : تطبيق البرنامج المقترح :}

تم تطبيق البرنامج المقترح على أطفال المجموعة التجريييـة وعــدها

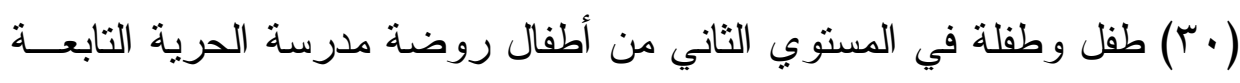

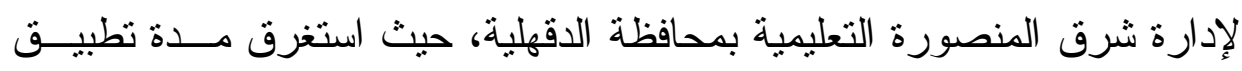

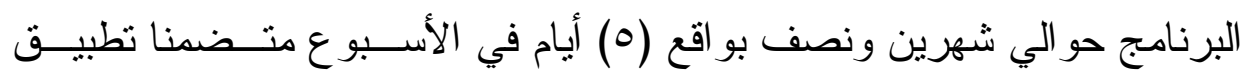

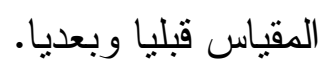

(") ملحق (ץ) برنامج الأشطة الفنية لتنمية القيم الاقتصادية. 
بعد الانتهاء من تطبيق البرنامج للأنشطة الفنبة لتتمية القيم الاقتــصادية

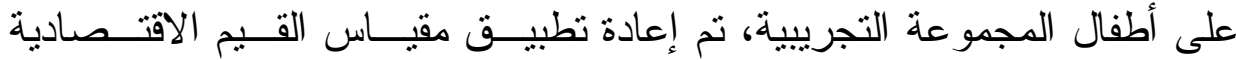
المصور على عينة البحث المجمو عتين (التجريبية و الضابطة) بصورة بعدية في

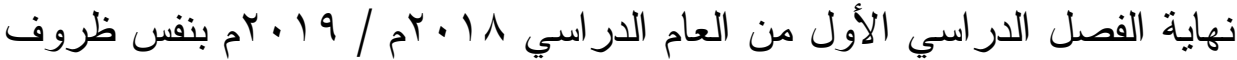
وتزتيب القياس القبلي من حيث زمن تطبيق المقياس على كـلـل طفـلـل بــصورة فردية، وتم تصحيح الإجابات ورصد الارجات للقياس البعدي استعدادا لإجــر اء المعالجات الإحصائية وجدولة النتائج. • الأساليب الإحصائية المستخدمة في تحليل ومعالجة البيانات تم معالجة البيانات الخاصة بمتغير ات الدر اسة عن طريق برنامج حـزم التحليل الإحصائي للعلوم الاجتماعية IBM SPSS Statistics ver.21؛ وقد تم اختيار مستوي معنوية عند ا +., • للتأكد من معنويـــة النتــائج الإحــصائية، وتضمنت خطة المعالجات الإحصائية الأساليب التالية : - معادلة المتوسط الحسابي Average. - معادلة الانحر اف المعيارى Standard Deviation. - معادلة بيرسون Pearson Coefficient لحساب الصدق " التجـــس الداخلى " لأداة البحث - معادلة ألفا كرنباخ Alfa Cronbach لحساب التبات لأداة البحث . - معادلة هوفستانر Hofstaetter لحساب درجة و اقعية المقياس • 
- معادلة " ت" لمجمو عتنن غيــر مــرتبطنين T-Test Independent لبحث دلالة الفروق بين متوسطى درجات كل من المجمو عتين التجريبية

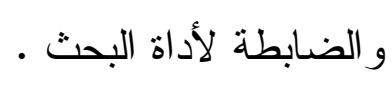

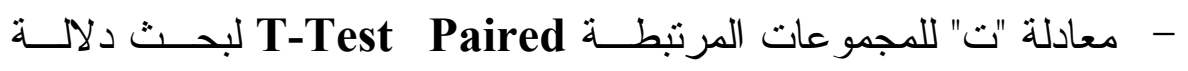

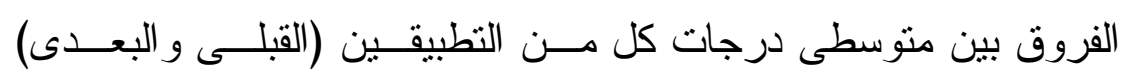

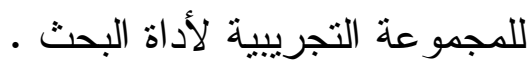

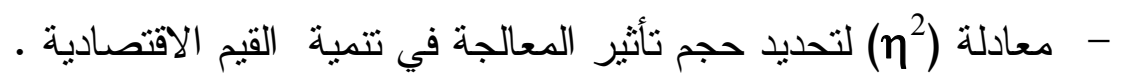
• عرض النتائج الخاصة بمقياس القيم الاقتصادية المصور:

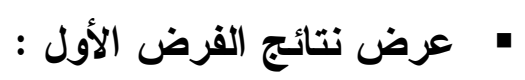

للتحقق من صحة الفرض الأول الذي ينص على:"توجد فروق ذو دلالة إحصائية عند مستوى دلاة هـ ., . ، بين متوسطى درجات أطفال المجمــوعتين

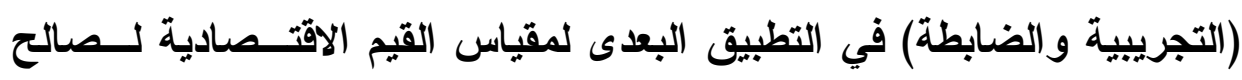
المجموعة التجريبية".

استخدمت الباحثة معادلة "ت" لهجمو عتين غير مـــتبطنتين؛ لبحـــث دلالـــة الفروق بين متوسطى درجات كل من المجموعتين التجرييية و الضابطة في القيم

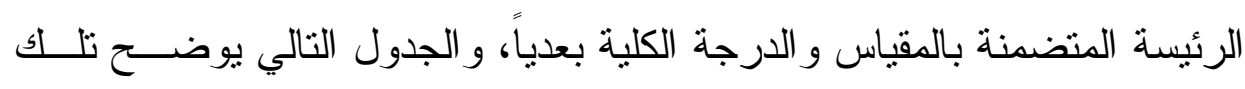
النتائج 
جدول (9)

قيمة "ت" ودلالتها الإحصائية للفروق بين متوسطى درجات كل من

المجموعتين (التجريبية و الضابطة) في المقياس و الارجة الكلية بعدياً

\begin{tabular}{|c|c|c|c|c|c|c|c|}
\hline مستوى & قيم ت & الحرية & المعيارى & | المتوسط & العدد & المجموعة & بالمقياس المتضمنة \\
\hline \multirow{2}{*}{ دالة } & \multirow{2}{*}{$9, \cdot 1$} & \multirow{2}{*}{01} & 1,0 r & $9,9 \vee$ & $r$. & تجريبية & \multirow{2}{*}{ ترشيد الاستهلاك } \\
\hline & & & $1,0 Y$ & $\uparrow, \varepsilon$. & $r$. & ضابطة & \\
\hline \multirow{2}{*}{ دالة } & \multirow{2}{*}{$\wedge, 9 \wedge$} & \multirow{2}{*}{01} & $1, \varepsilon$. & $11, r$. & $r$. & تجريبية & \multirow{2}{*}{ قيمة الإنفاق } \\
\hline & & & l, ^. & $V, \varepsilon V$ & $r$. & ضابطة & \\
\hline \multirow{2}{*}{ دالة } & \multirow{2}{*}{$\Lambda, r_{O}$} & \multirow{2}{*}{01} & $\overline{l, \lambda r}$ & $R, r$. & $r$. & تجريبية & \multirow{2}{*}{ قيمة الادخار } \\
\hline & & & $r, \cdot r$ & $\Lambda, r$. & $r$. & ضابطة & \\
\hline \multirow{2}{*}{ دالة } & \multirow{2}{*}{$1 \cdot, r V$} & \multirow{2}{*}{01} & $1,7 \varepsilon$ & $1 Y, q 4$ & $r$. & تجرييية & \multirow{2}{*}{ قيمة العمل } \\
\hline & & & l,Av & $\Lambda, Y V$ & $r$. & ضابطة & \\
\hline \multirow[b]{2}{*}{ دالة } & \multirow[b]{2}{*}{7,79} & \multirow[b]{2}{*}{01} & $r, r)$ & $11, V \pi$ & $r$. & تجريبية & \multirow{2}{*}{ قأصحاب المهن احتر } \\
\hline & & & r,or & $v, \pi$ & $r$. & ضابطة & \\
\hline \multirow{2}{*}{ دالة } & \multirow{2}{*}{$10, V_{0}$} & \multirow{2}{*}{01} & ז & $\Delta \wedge, 1 \mu$ & $r$. & تجريبية & \multirow{2}{*}{ المقياس ككل } \\
\hline & & & $0, \wedge 4$ & $r v, q v$ & $r$. & ضابطة & \\
\hline
\end{tabular}

يتضح من الجدول وجود فروق ذو دلالة إحصائية بين منوسطى درجات

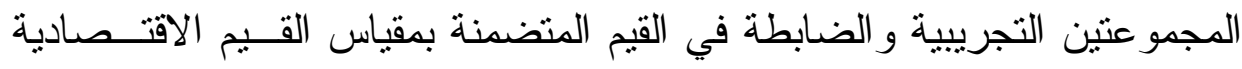

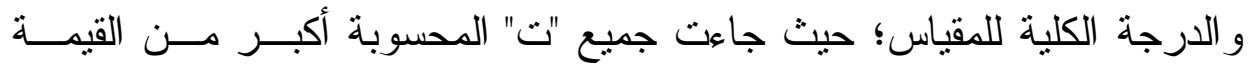

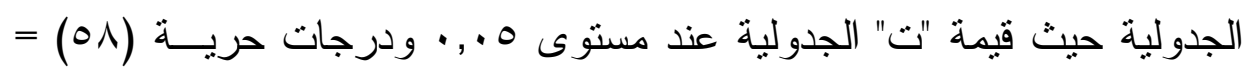


(1, 91)؛ مما بدل على تفوق المجموعة التجريبية على المجموعة الضابطة فـي

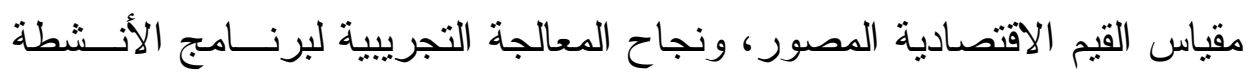

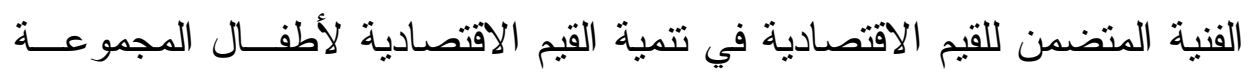
التجريبية.

وفى ضوء تلاكك النتيجة، يمكن قبول الفرض الأول من فروض البحــث

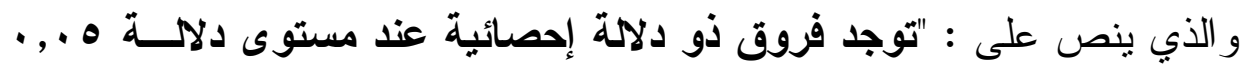

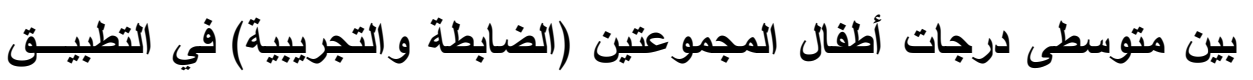
البعدى لمقياس القيم الاقتصادية لصالح المجموعة التجريبية " لئول • عرض نتائج الفرض الثاني :

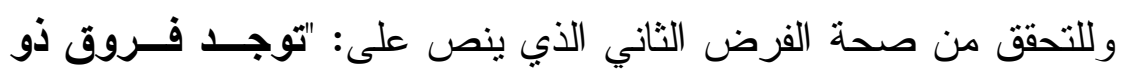

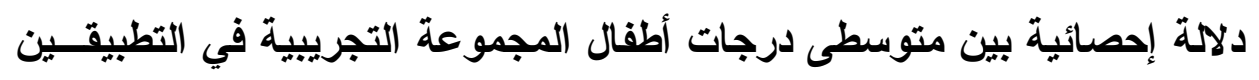

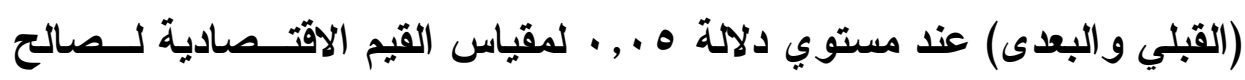

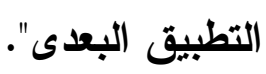

استخدمت الباحثة معادلة "ت" للمجموعات المرتبطة لبحث دلالة الفــروق

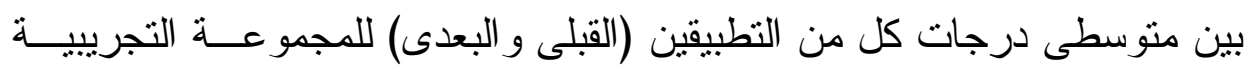

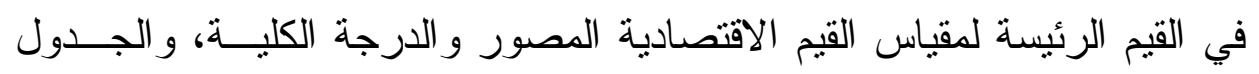

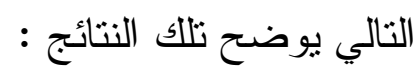




\section{جدول (·)}

قيمة "ت" ودلالتها الإحصائية للقروق بين متوسطى درجات كل من التطبيقين

(القبلى والبعدى) للمجموعة التجريبية في القيم الرئيسة للمقياس و الارجة الكلية

\begin{tabular}{|c|c|c|c|c|c|c|c|}
\hline مستوى & قيم ت & الحرية & الاتحر اف & المتوسط & العدد العد & القياس & بالمقيم المتضمنة \\
\hline \multirow{2}{*}{ 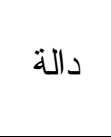 } & \multirow{2}{*}{$9, \wedge 9$} & \multirow{2}{*}{ rq } & $1,0 \mathrm{r}$ & $9,9 \vee$ & $r$. & بعدى & \multirow{2}{*}{ ترشيد الاستهلك } \\
\hline & & & $1, r Y$ & $\tau, \Gamma V$ & $r$. & قبلى & \\
\hline \multirow{2}{*}{ دالة ل } & \multirow{2}{*}{$9, Y_{1}$} & \multirow{2}{*}{ rq } & $1, \varepsilon$. & $11, r$. & r. & بعدى & \multirow{2}{*}{ قيمة الإنفاق } \\
\hline & & & 1,10 & $\vee, \varepsilon r$ & r. & قبلى & \\
\hline \multirow{2}{*}{ 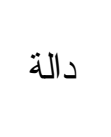 } & \multirow{2}{*}{$\wedge, \Gamma \wedge$} & \multirow{2}{*}{ rq } & $1, \wedge r$ & Ir,r. & r. & بعدى & \multirow{2}{*}{ قيمة الادخار } \\
\hline & & & 1,7 & $\wedge, 1$. & $r$. & قبلى & \\
\hline \multirow{2}{*}{ دالة } & \multirow{2}{*}{$1 \cdot, 11$} & \multirow{2}{*}{ rq } & $1,7 \varepsilon$ & $\mid r, q r$ & $r$ & بعدى & \multirow{2}{*}{ قيمة العمل } \\
\hline & & & $1, \pi r$ & $\Lambda, Y V$ & r. & 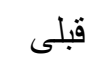 & \\
\hline \multirow{2}{*}{ دالة } & \multirow{2}{*}{$\vee, 乏 q$} & \multirow{2}{*}{ rq } & $r, Y_{1}$ & $11, \mathrm{~V}$ & $r$. & بعدى & \multirow{2}{*}{ قيمة احترام أصحاب } \\
\hline & & & I, I & $\vee, \wedge$. & $r$. & 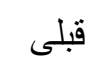 & \\
\hline \multirow{2}{*}{ دالة } & \multirow{2}{*}{$r_{1, Y 1}$} & \multirow{2}{*}{ rq } & $r, \wedge \uparrow$ & $\bullet \wedge, 1 \mu$ & $r$ & بعدى & \multirow{2}{*}{ المقياس ككل } \\
\hline & & & r, qV & $r v, q v$ & $\mu$. & قبلى & \\
\hline
\end{tabular}

يتضح من الجدول السابق وجود فروق ذو دلالة إحصائية بين متوســطى

درجات التطبيقين (القبلى و البعدى) في المجموعة التجريبية في القـيم الرئيسـة

للمقياس و الدرجة الكلية للمقياس؛ حيث جاءت جميع قيم "ت" المحسوبة أكبر من القيمة الجدولية حيث بلغت قيمة "ت" الجدولية عند مـستوى (0. . •) ودرجـات

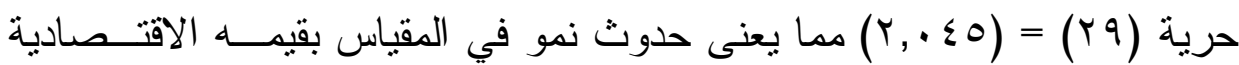
الرئيسة لدى المجمو عة التجريبية. 
وفى ضوء تلكك النتائج، يمكن قبول الفرض الثاني من فـروض البحــث و الذي بنص على: "توجد فروق ذو دلالة إحصائية عند مستوى (ه +, •) بـين متوسطي درجات أطفال المجموعة التجريبية في التطبيقين (القبلي والبعـدى) لمقياس القيم الاقتصادية لصالح التطبيق البعدى". • فعالية المعالجة التجريبية في تنمية القيم الاقتصادية (حجم التأثير) : لتحديد فعالية المعالجة التجريبية في تتمية القيم الاقتصادية؛ قامت الباحثة

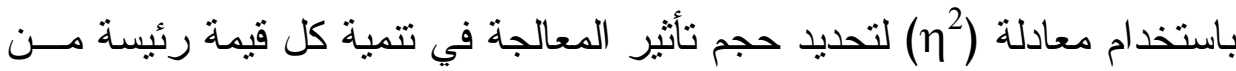

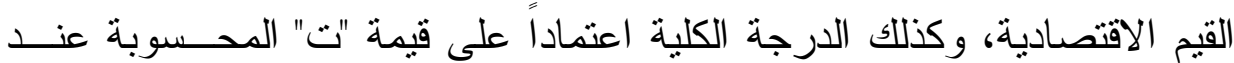
تحديد دلالة الفروق بين التطبيقين (القبالـي و البعــدى) للمجموعــة التجريبيــة، و الجدول التالي يوضـح ذلك :

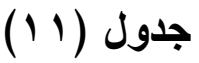

قيمة (ך) وحجم تأثير المعالجة التجريبية في تنمية القيم الرئيسة لمقياس القيم الاقتصادية و الارجة الكلية

\begin{tabular}{|c|c|c|c|}
\hline حجم التأثير & $\eta^{2}$ & قيم (ت) & القيم المتضمنة بالمقياس \\
\hline كبير & $\cdot, \mathrm{VV}$ & $9, \wedge 9$ & ترشيد الاستهلك \\
\hline كبير & $\cdot, V_{0}$ & $9, Y_{1}$ & قيمة الإنفاق \\
\hline كبير & $\cdot, V_{1}$ & $\wedge, r \wedge$ & 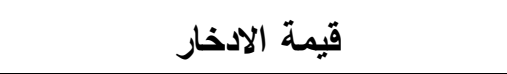 \\
\hline كبير & $\cdot, \mathrm{\vee} \wedge$ & $1 \cdot, 11$ & قيمة العمل \\
\hline 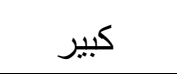 & • & $\vee, \varepsilon q$ & قيمة احتر ام أصحاب المهن وتقديرهم \\
\hline كبيز & $\cdot, 94$ & $r 1, r)$ & المقياس ككل \\
\hline
\end{tabular}




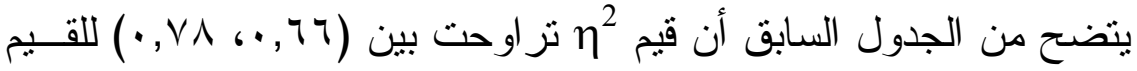

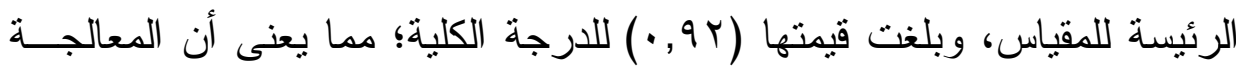

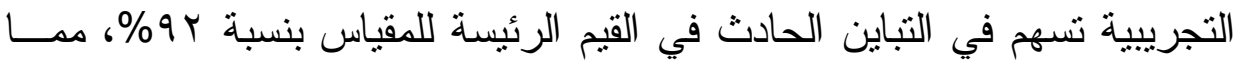

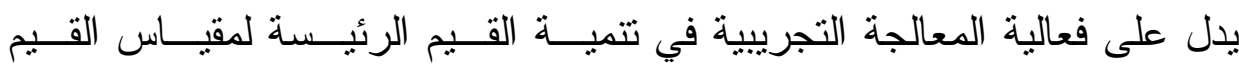
الاقتصادية المصور لاى المجموعة التجريبية.

• مناقثة وتفسير النتائج الخاصة بتطبيق برنامج الأنثطة الفنية لتنميــة

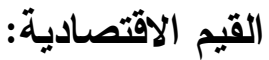

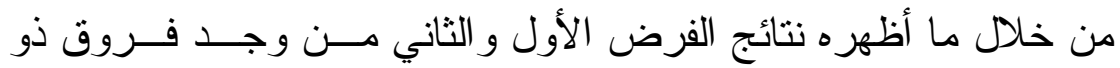

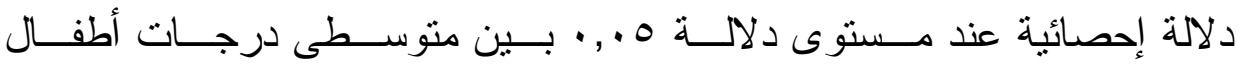
المجمو عتين (التجريبية و الضابطة) في التطبيق البعدى لمقياس القيم الاقتــصادية

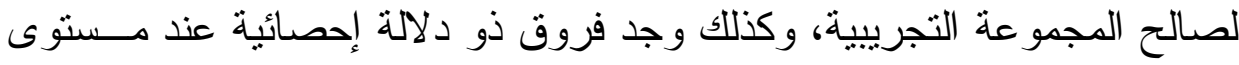

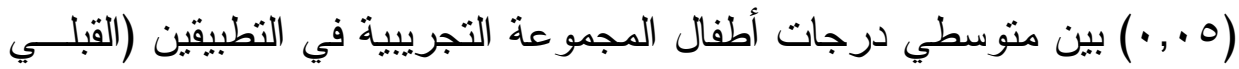

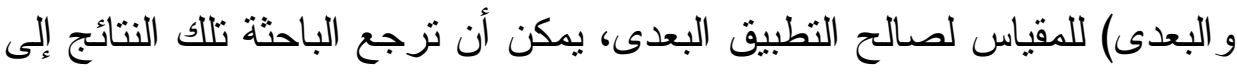

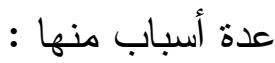

- فاعلية البرنامج المقترح القائم على الأنشطة الفنية كأساس للحتو اهوهـــ :

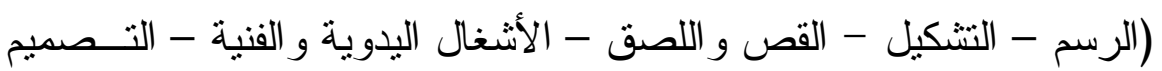

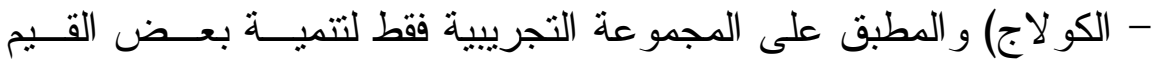

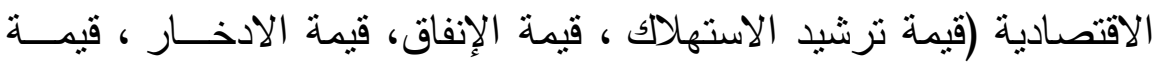
العمل، قيمة احتر ام أصحاب المهن وتقدير هم) لطفل الروضة.

- وضوح الأهداف السلوكية الخاصة بكل قيمة من القيم الاقتصادية وتتوعهـــا

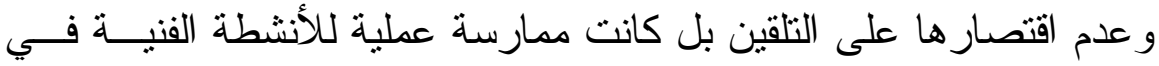


مجمو عات مما ساعد ذلك على تحقيق هذه الأهـــداف وتقويمهــا بــصورة شاملة ومستمرة.

- استخدام الدر اسة عدة استر اتيجيات تعليمية بالبرنامج المقتر ح مــن خــلال

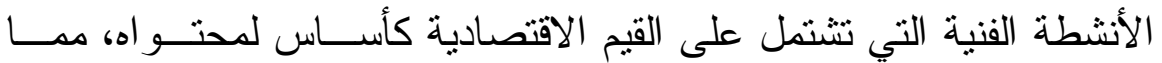
ساعد الطفل علي توفير بيئة آمنه تشجع الطفل على التعلم. - ايجابية الأطفال أثتاء ممارسة الأنشطة الفنية وتعاونهم معا فـي الأعمــال اليدوية و الممارسات العملية منل عمل المجسمات و الأشكال، حيــث بــسهر

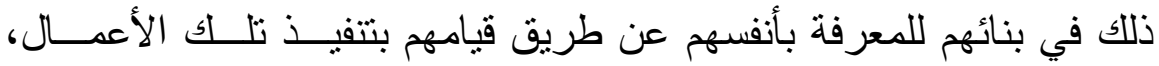
و إعادتها إذا رغبو ا في ذلك وقيامهم كذلك بالملاحظة و الاستتتاج ومناقـشة نتائج أعمالهم معا ومع المعلمة مما يساعد ذلك على الاحتفاظ بــأثز الــتعلم لمدة أطول، وتتفق هذه النتائج مع نتائج الدراسات السابقة التي اســتخدمت الأنشطة الفنية منل در اسة (محمد عباس، ^ . . ب)، ودر اسة (ايمن إير اهيم،

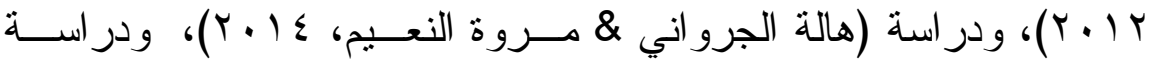

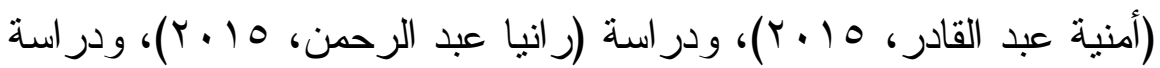

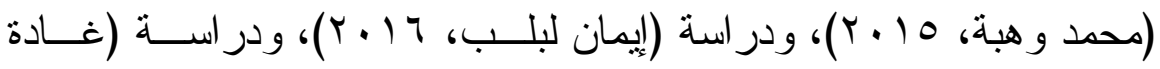

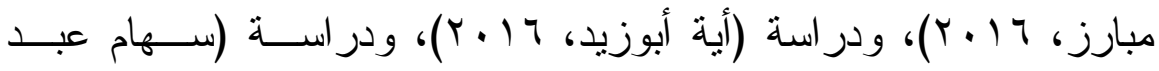

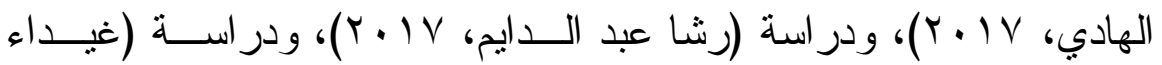

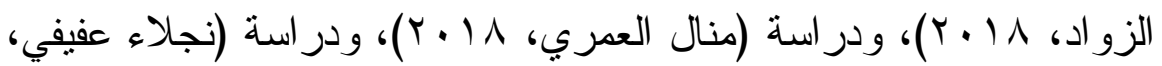
$\cdot(r \cdot 11$

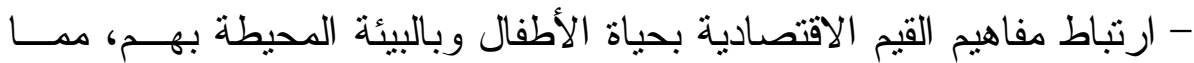
يجعلهم مهتمين بتعلم هذه القيم الاقتصادية و الاستفادة منها. 
- يوفر البرنامج المقترح باستخدام الأنثطة الفنبــة بيئــة غنيــة بــالمثير ات

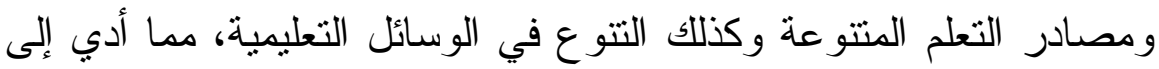

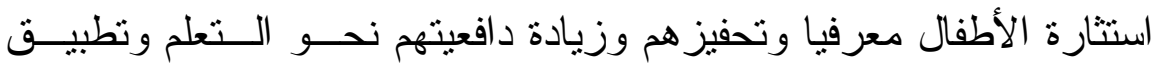
مفاهيم القيم الاقتصادية وارتباطه ببيئة الطفل ساعد على انتقال أثز التعلم.

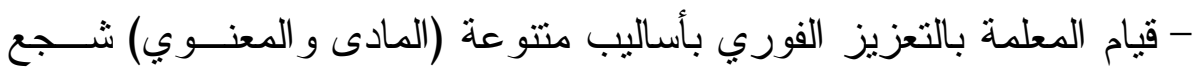
الأطفال الالتز ام في المشاركة في الأنثطة الفنية. - التقويم المتنوع و المستمر في نهاية كل نشاط من الأنشطة ساعد على زيادة

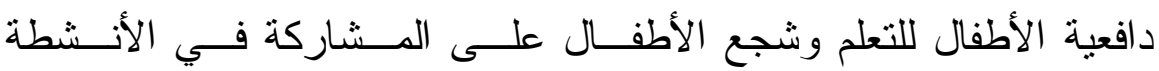
ومناقشتها. - مر اعاة برنامج الأنثطة الفنية لحاجات الطفل و اهتماماته، وكذللك مر اعـاة الفروق الفردية بين الأطفال. - مر اعاة المعلمة لجو انب النوجيه و الإرشاد و المتابعة و الثقويم للأطفال أثتـــاء

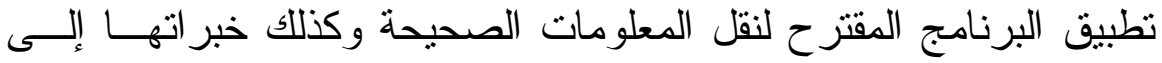

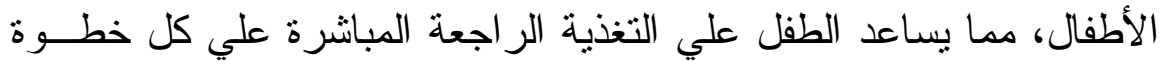
من الخطوات التي يقوم بها عند تتفيذ النشاط. - ترك المعلمة فرصة للطفل لتعديل النثاط الذي قام به وتطويره إذا اخطأ ثم

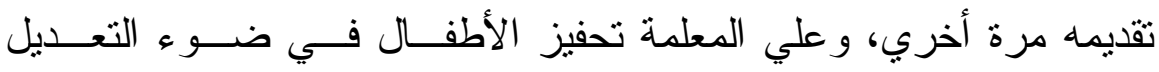
و التطوير الذي قام به. - منح المعلمة الأطفال فرصة لإبداء الر أي في نشاطهم، فنلك ينمـي تقـدير الذات لدي الطفل. 
- منح المعلمة الأطفال فرصة في مناقثنة أنشطة زملائهم وذلك لتتمية الثقــة

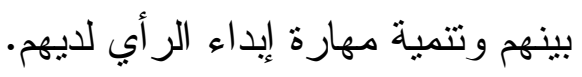

كما تتفق هذه النتائج مع نتائج در اسات أخري قامت بتتمية مفاهيم القـيم

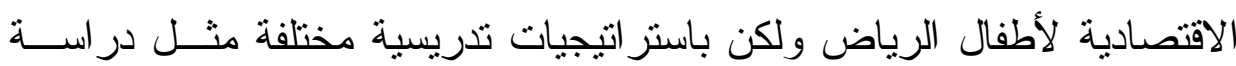

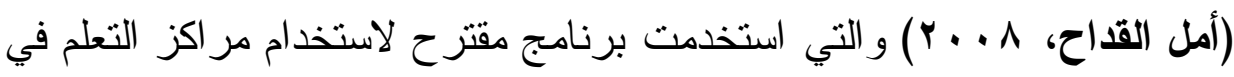

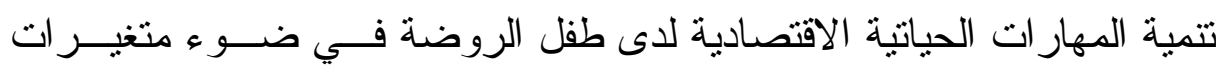

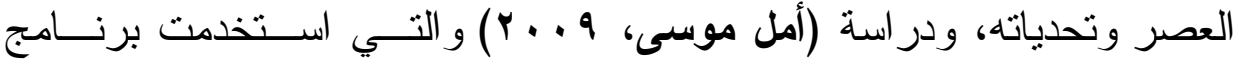

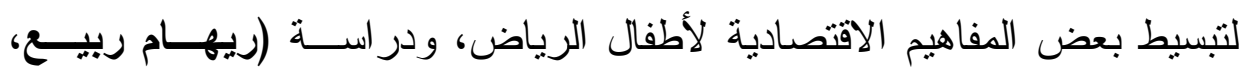

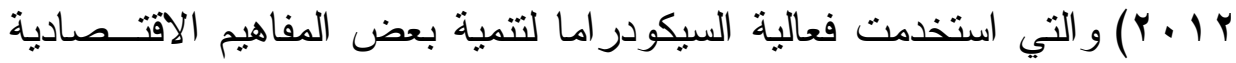

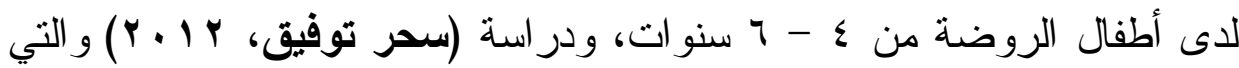

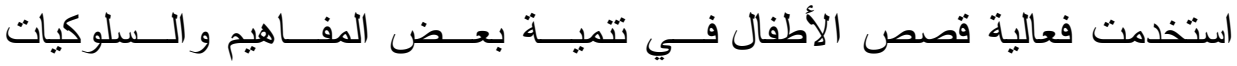

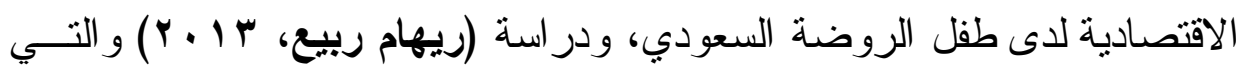
استخدمت تتمية بعض المفاهيم الإقتصادية باستخدام الأنشطة المسرحية وعلاقتها

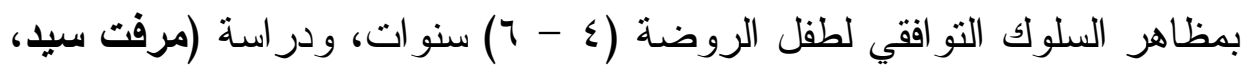

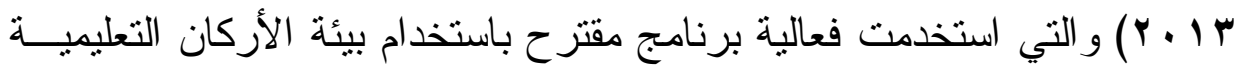

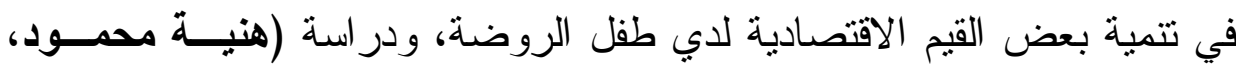

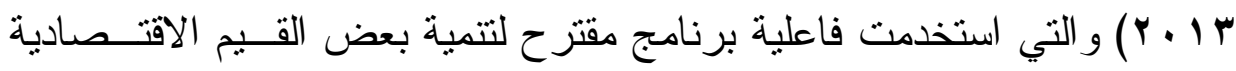

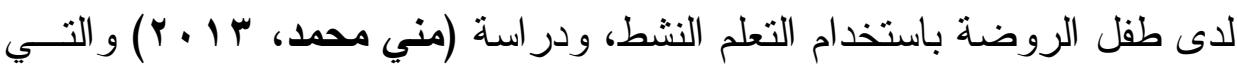

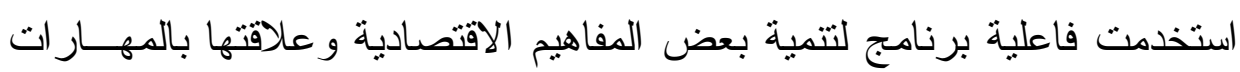

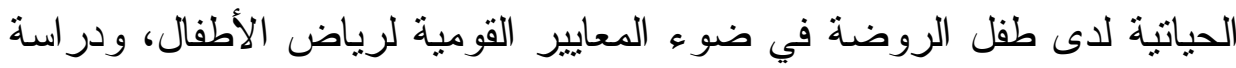

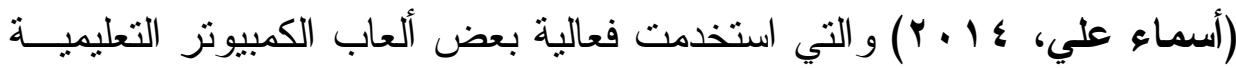

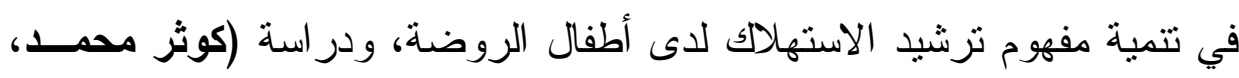




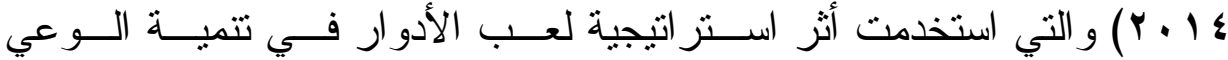

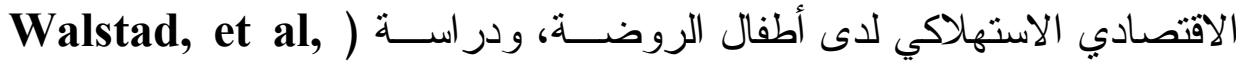

2015) و التي استخدمت وجهات نظر حول الاقتصادية في المناهج الدراسـية :

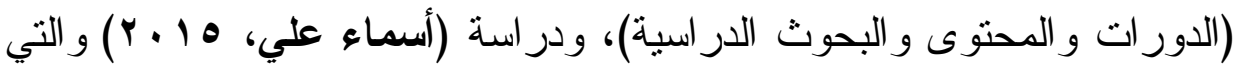
استخدمت فعالية برمجية ألعاب كمبيوتر تعليمية في تتمية بعض المفاهيم و الميول

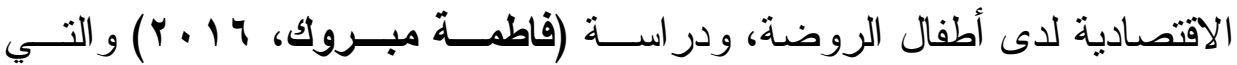
استخذمت دور المسرح القومي للطفل في تتمية القيم المختلفة، ودر اســـة (نــورة

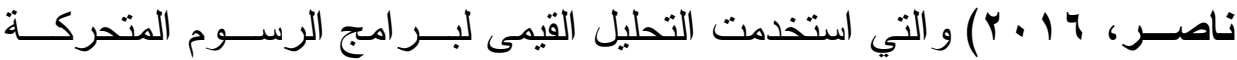

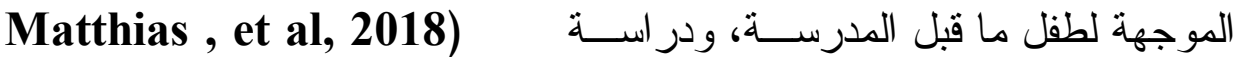
Sutter و التي استخدمت السلوك الاقتصادي للأطفال و المر اهقين عن طريـق

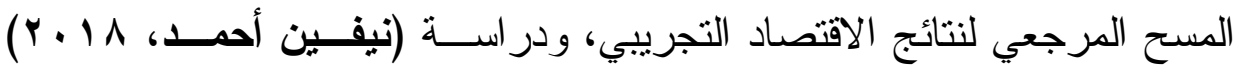

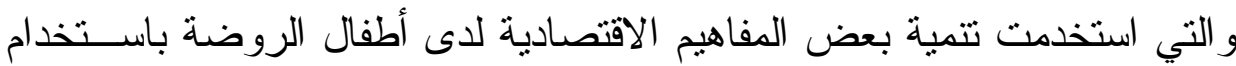

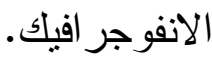

\section{- نتائج الدر اسة :}

1- وجود فروق ذو دلالة إحصائية عند مستوى دلالة ه., • بين متوسـطى

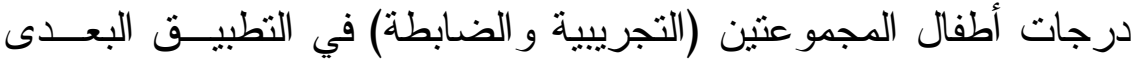
لمقياس القيم الاقتصادية لصالح المجموعة التجريبية. ץ- وجود فروق ذو دلالة إحصائية عند مسستوى (0. , ) بـين منتوســي درجات أطفال المجموعة التجريبية في التطبيقين (القبلي و البعدى) لمقياس القيم الاقتصادية لصالح التطبيق البعدى. 
r- فاعلية البرنامج القائم على الأنثطة الفنية بمحتواة (الرسم - التـشكيل -

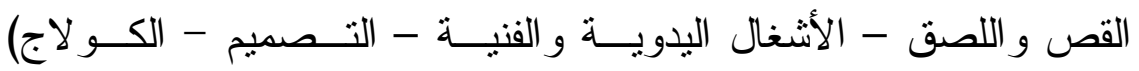

و المطبق على المجموعة التجريبية فقط لتتمية بعض القـيم الاقتـصـية

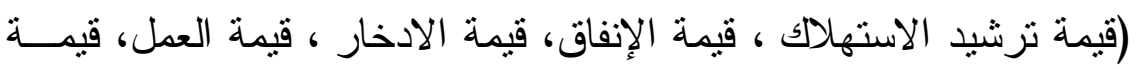

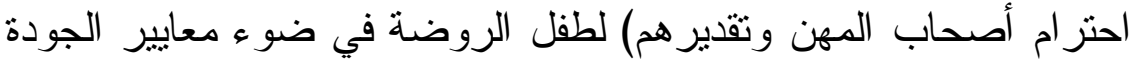

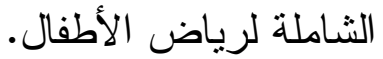

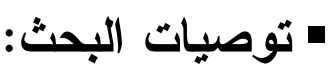

في ضوء النتائج والإستخلاصات التي تم التوصل إليها تثقام الباحثـة

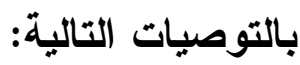

- إدر اج وتطبيق البرنامج القائم على استخدام الأنشطة الفنــــة فـــي منــاهج

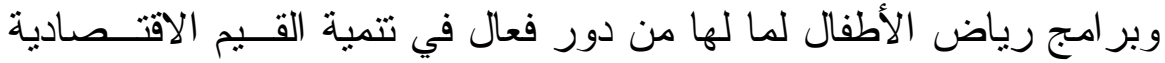

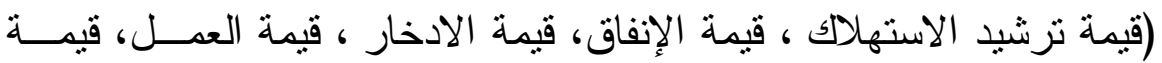

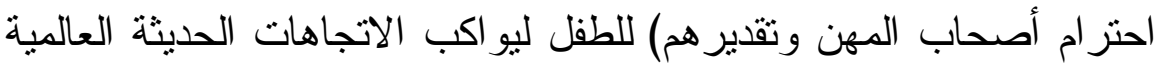

في تربية طفل الروضة وتحقيق أهداف التربية العطلية في رياض الأطفال.

- استخدام مقياس القيم الاقتصـادية المصور التي قامــت الباحتــهـه بتصميمه

و تقنينه، لقياس فعالية هذه القيم للأطفال.

- العمل على إجر اء دراسات مشابهه باستخدام الأنشطة الفنبة ولكن بالنسـبة لأطفال المستوي الأول لرياض الأطفال.

- ضرورة عقد ندوات ودور ات تدريبية تتعلق بتطبيـق البرنــامج باســتخدام الأنشطة الفنية لتثقيف معلمات الروضة أثناء الخدمة وكذلك طالبـات كليــة رياض الأطفال بأهمية وطرق تتمية القيم الاقتصادية. 
- توظيف بعض اللوحات الإرشادية في الروضة لتوضيح القـيم الاقتــصادية

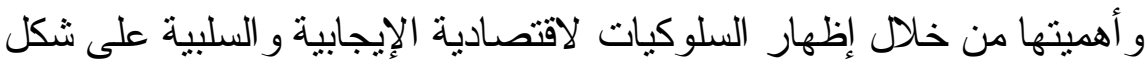
رسومات محبية للطفل وشرحها له.

- ضرورة إطلاع معلمات الرياض على آخر ما توصلت إليه نتائج الأبحـاث العلمية. - ضرورة التعاون بين المعلمة و الأسرة عن طريق عقد لقاءات تربوية دورية ومستمرة بينهما وكذلك القيادات التزبوية المتخصصة في الروضات لتنقيفهم بمفاهيم القيم الاقتصادية، من خلال تفعيل حضور مجــالس أوليــاء أمــور الأطفال لمناقثة السلوكيات التي ترتبط بالقيم الاقتصادية، لتعزيز السلوكيات

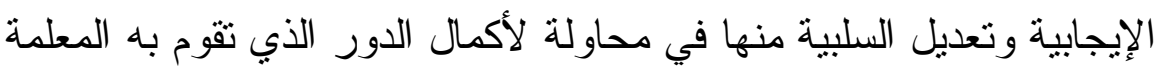

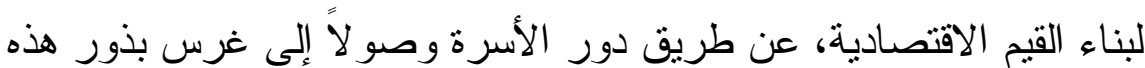
القيم بشكل سليم لاى الطفل منذ صغره، وخصوصاً قيمة الادخار التي تتطلب متابعة من قبل الو الدين و المعلمة على حد سو اء.

- ضرورة تتوع الأنشطة المقدمة للطفل لعدم الملــل و الرتابــة مثــل تتظـــيم رحلات أو زيار ات ميدانية أو استخدام المؤثرات الحسية و الوسائل التعليمية المختلفة من اللعب و الموسيقى و الغناء و اســتخدام خامــات البيئــة ولعــبـ الأدو ار و التجارب العملية وغير ها في تعليم الأطفال مع مر اعــاة التكامـلـل و التر ابط في الأنشطة المقدمة. - مشاركة وسائل الإعلام في دعم وتتمية القيم الاقتصادية الإيجابية و الحد من القيم الاقتصادية السلبية وذلك من خلال البر امج الهادفة الموجهة للأطفال. 
- حث القائمين على عملية التعليم على التركيز على إكساب الأطفال مهارات

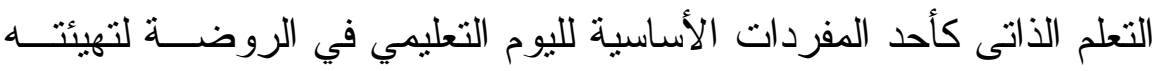

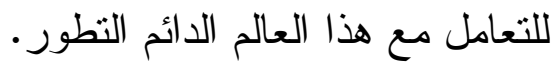
- نوفير فرص لممارسات عملية تشرك المعلمة فيها الأطفال من خلالها كايجاد حصالة للطفل في الروضة وتو عيته بأهية الادخار وتحقيق النفعية بينه وبين

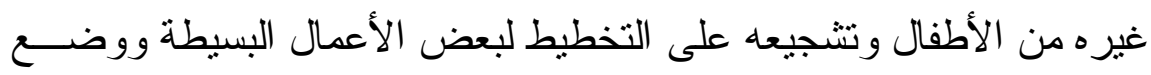

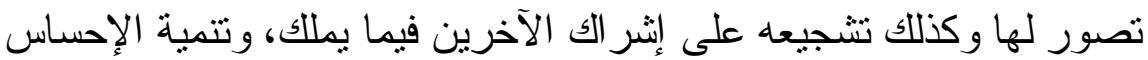
لايه بضرورة المشاركة في نشاطات. - إغناء مكتبة الروضة بالقصص المناسبة التي تنزي القيم الاقتــصادية لـــى الطفل. - العلاء

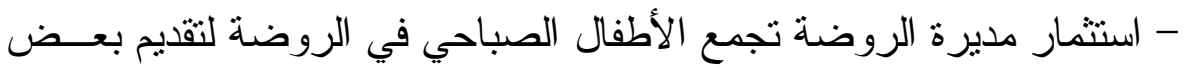
التوجيهات التي لها دور في تتمية القيم الاقتصادية لديهم. - يجب الاهتمام من قبل الروضات بتوفير الوسائل و الأدوات اللازمة لإجر اء الأنشطة لما لها من اثز اليجابي في تحقيق أهداف التعلم. - يجب على معلمات الرياض الاهتمام بالجو انب الوجدانيــة إلــى الجوانــب المعرفية عند إعداد الأنشطة العلمية للطفل.

- إعداد دليل لمعلمة الروضة يساعدها في كيفية اســتخدام الأنـشطة الفنــــة بطريقة صحيحة مع الأطفال لتتمية مفاهيم القيم الاقتصادية لديهم. 
• در اسات وبحوث مقترحة :

في ضوء نتائج البحث الحالية يمكن اقتراح دراسات وبحوث على النحو

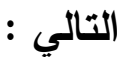

1- در اسة فعالية الأنشطة الفنية في مجالات أخري مختلفــة ســــاء كانـــ (اجتماعية، حركية، فنية، عقلية).

ץ- دراسة فعالية استخدام الأنشطة الفنية على زيادة دافعيه أطفال الروضـــة

$$
\text { وتتمية قدر اتهم على التفكير العلمي الابتكاري و الإبداعي. }
$$

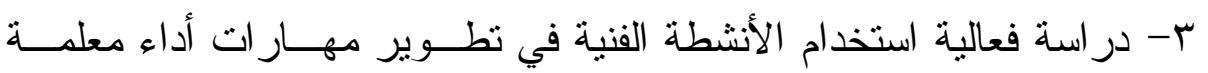

$$
\text { الروضة. }
$$

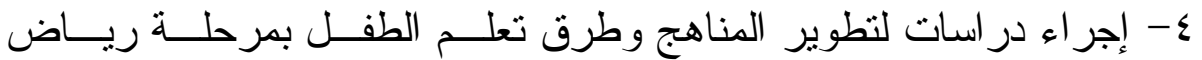

الأطفال في ضوء وثيقة المعايير القومية برياض الأطفال في مصر .

ه- فاعلية برنامج أنشطة فنية فـي تتميــة الـــوعي المعرفــى و الإدر اكـي

$$
\text { و الوجداني لدى طفل الروضة }
$$

7- إجر اء دراسات تحليلية لنتائج الدراسات التي استخدمت الأنسـشة الفنيـــة

$$
\text { وكذلك القيم الاقتصادية في رياض الأطفال. }
$$

V- در اسة أثر الأنشطة الفتية في تتمية القيم الاقتـصادية للمعـاقين سـمعيا

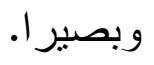




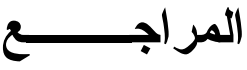

$$
\text { أولا : المراجع العربية : }
$$

1 - أحمد إبر اهيم ( • ( • r): إدارة الحياة في ترشيد الاستهلاك، الدار الأكاديمية

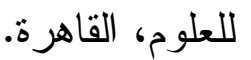

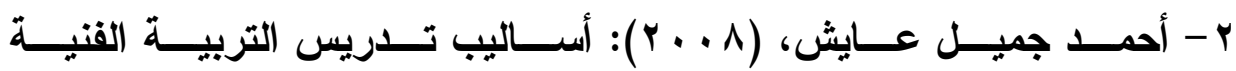
والمهنية والرياضية، الطبحسة الأولـي، دار المـسيرة للنـشر و التوزيـع

$$
\text { و الطباعة، عمان. - أن }
$$

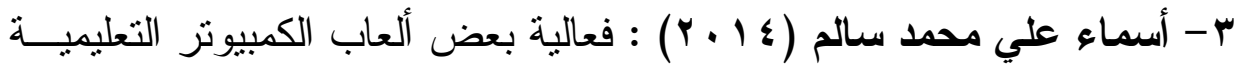
فى تتمية مفهوم ترشيد الاستهلاك لدى أطفال الروضة، مجلة التربية وثقافة الطقل، العدد ب، يوليو، كلية رياض الأطفال، جامعة المنيا.

צ - أسماء علي محمد سالم (10 • ب) : فعالية برمجية ألعاب كمبيونز تعليميــة في تتمية بعض المفاهيم و الميول الاقتصادية لدى أطفال الروضـــة، رســالة دكتوراه غير منشورة، كلية رياض الأطفال، جامعة المنيا، مصر .

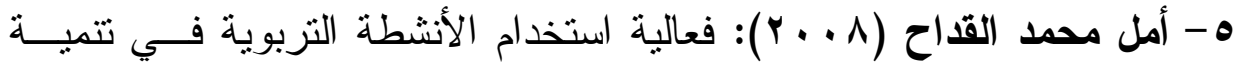
بعض مهار ات التفكير لدى أطفال الرياض، مجلة كلية التربية، عـدد 77، يناير ، كلية التربية، جامعة المنصورة.

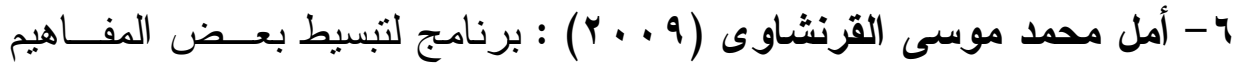

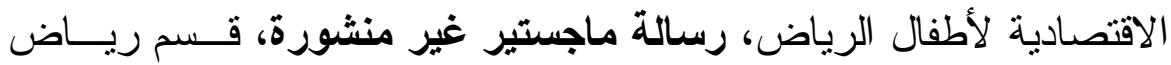
أطفال، كلية التربية، جامعة طنطا. 
- V أمنية محمد إبراهيم عبد القادر (10 • Y): أثز فاعلية برنامج أنشطة متحفية

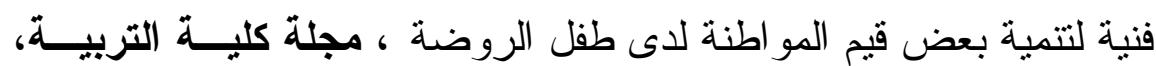
مجلد 0Y، عدد 0، كلية التربية، جامعة الإنكندرية.

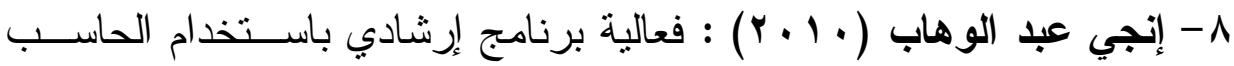

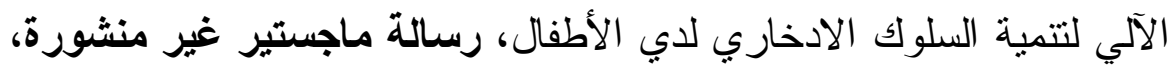
كلية الاقتصاد المنزلي، جامعة حلوان.

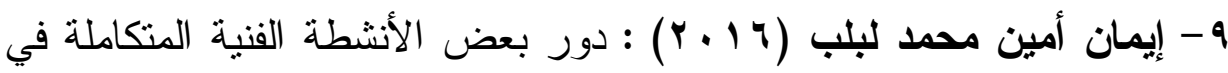

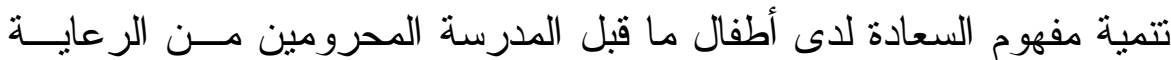

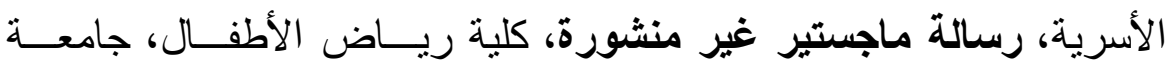
بورسعيد.

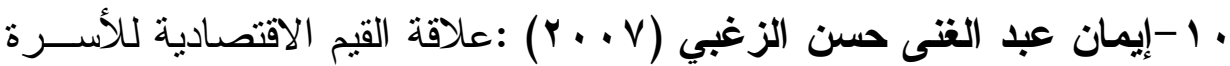

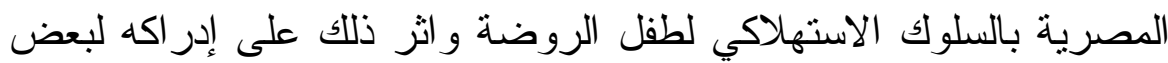

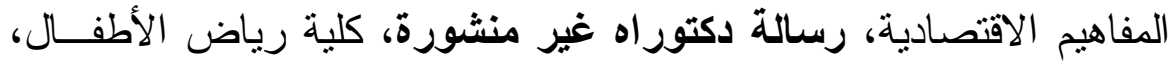

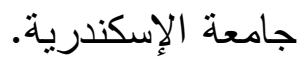

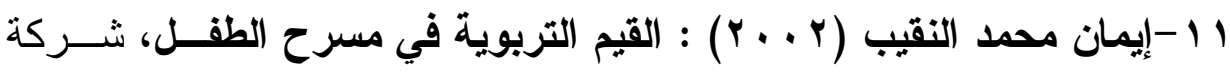
الجمهورية الحديثة للطباعة، الإسكندرية.

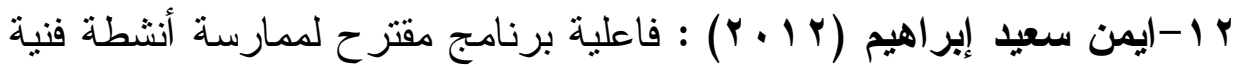

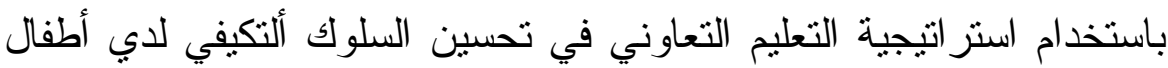

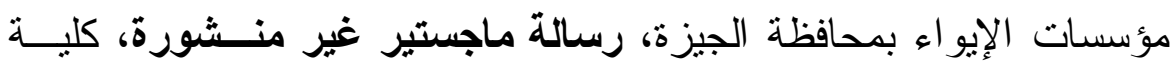
رياض الأطفال، جامعة القاهرة. 


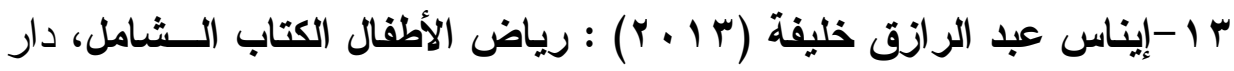
الفكر العربي، القاهرة.

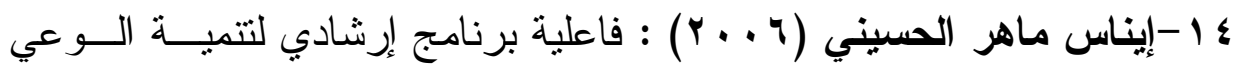

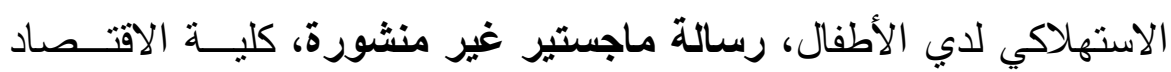

$$
\text { المنزلي، جامعة حلو ان. }
$$

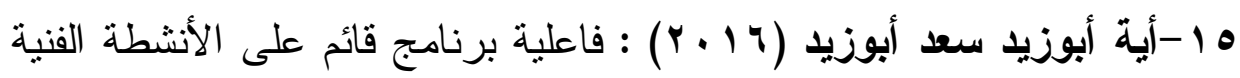

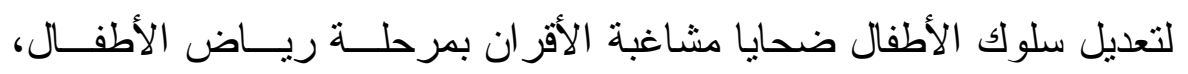
رسالة ماجستير غير منشورة، كلية النزبية، جامعة المنوفية.

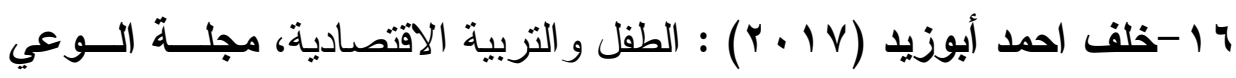

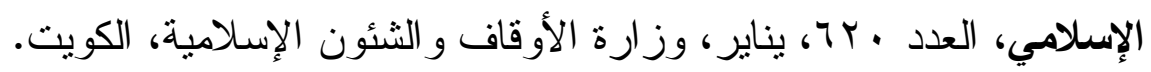

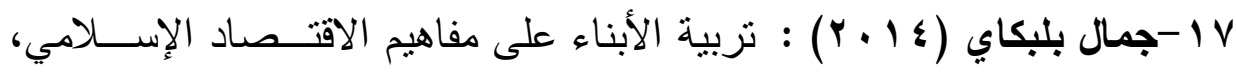

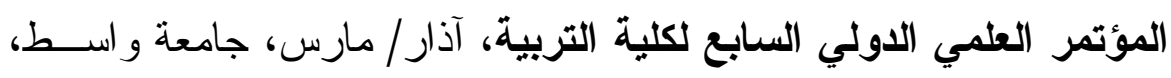

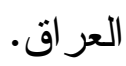

11-ر رانيا على ربيع عبد الرحمن (10 + ب): تتمية التفكير الإبداعي بإســتخدام

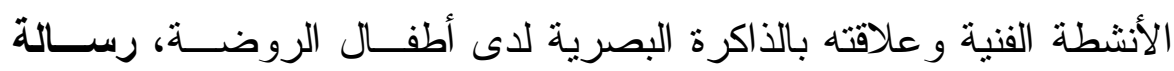
ماجستير غير منشورة، كلية رياض الأطفال، جامعة القاهرة.

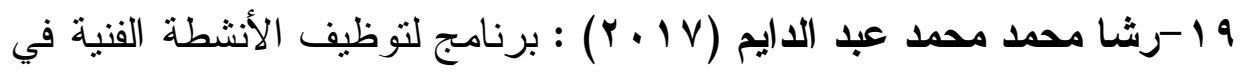

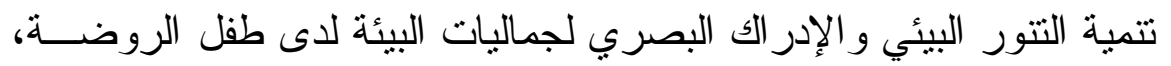

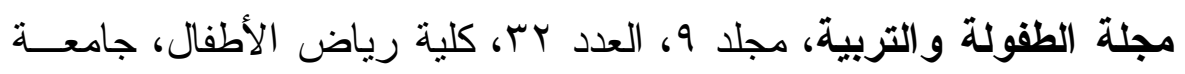
الإسكندرية 


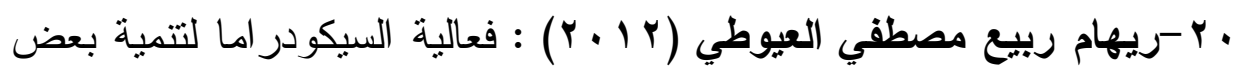

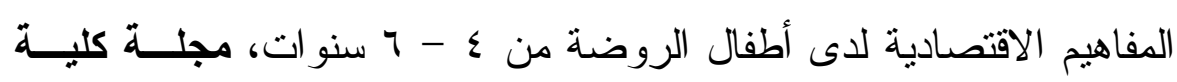

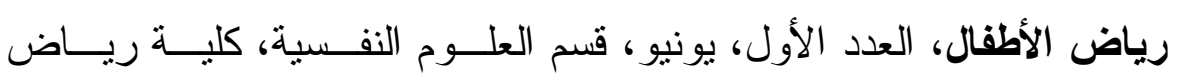

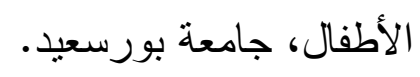

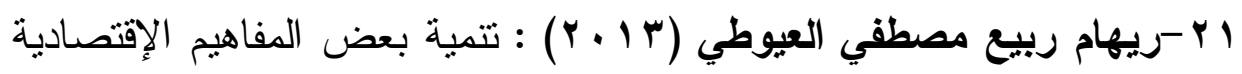

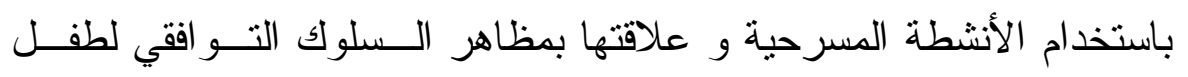

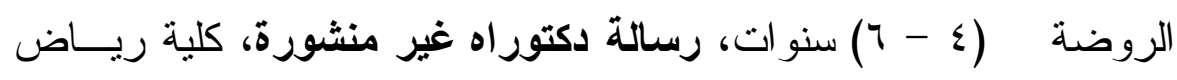
الأطفال، جامعة بورسعيد.

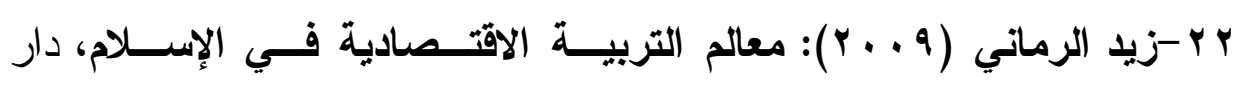
الورقات، الرياض، السعودية.

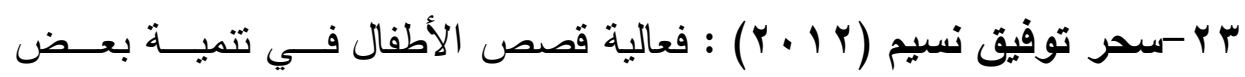

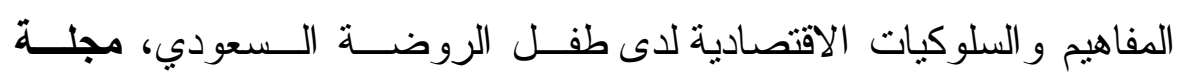

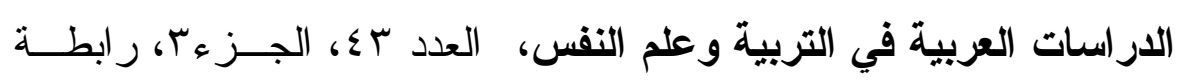
التربويين العرب، المملكة العربية السعودية.

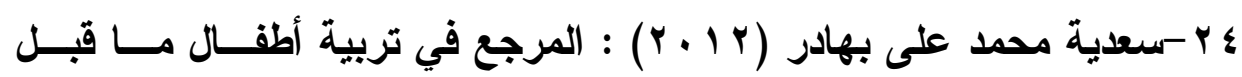
المدرسة، دار المسيرة للنشر و التوزيع، عمان، الأردن.

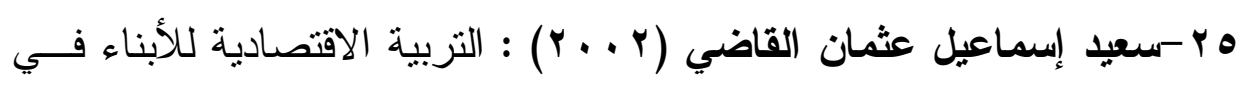

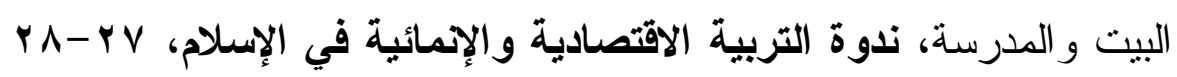

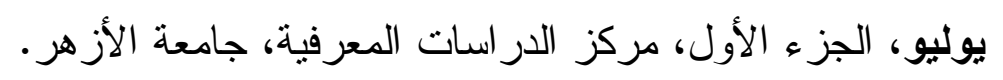

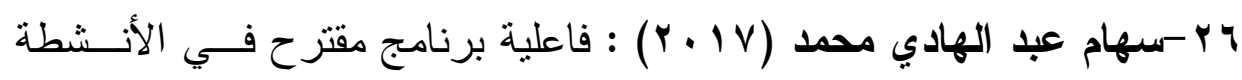

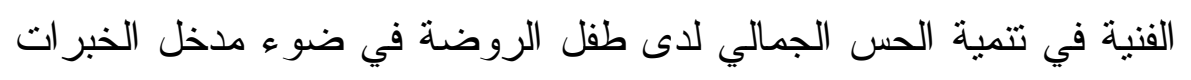

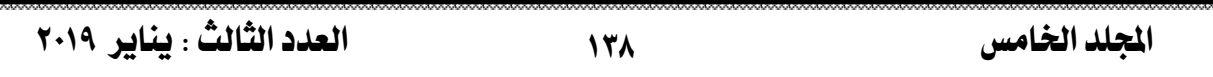




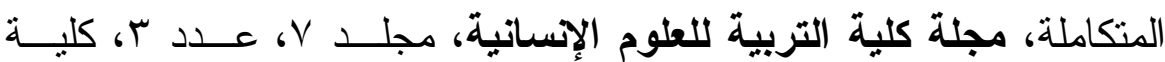
التزبية للعلوم الإنسانية، جامعة ذي قار ، العر اق.

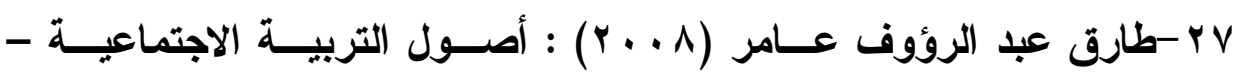
الثقافية الاقتصادية، دار المعارف، القاهرة.

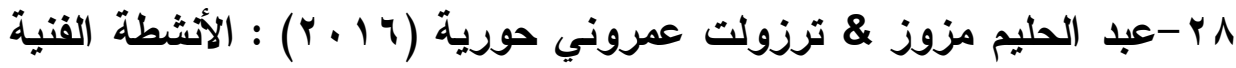

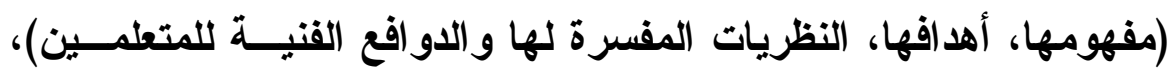
جامعة قاصدي مرباح، الجزائر.

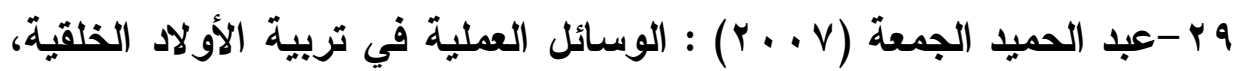
دار الأنصاري، حلب، سورية.

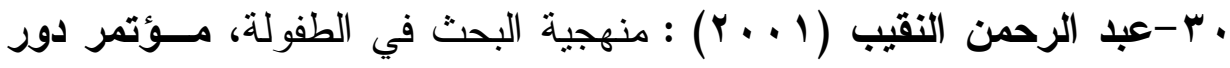

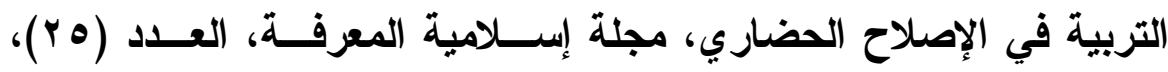

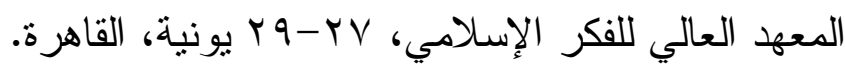

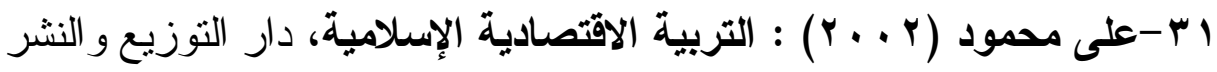

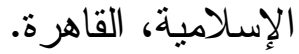

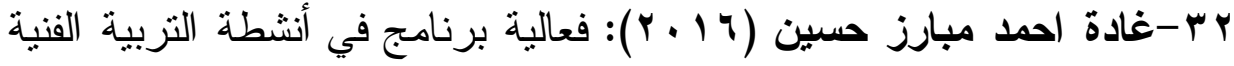

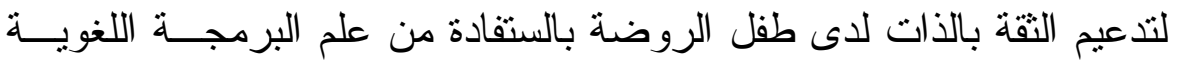
العصبية، رسالة ماجستير غير منشورة، كلية التربية الفنبة، جامعة حلوان.

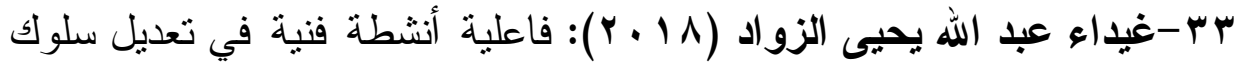

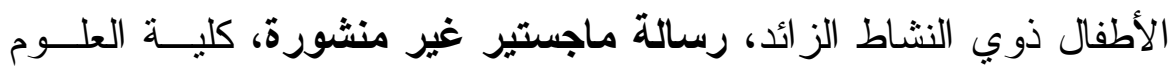
التربوية، جامعة الإسر اء الخاصة، الأردن. 


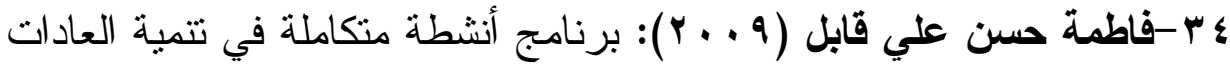
الفعالة لثخصية طفل الروضة، رسالة ماجستير غير منشورة، كلية رياض لئه

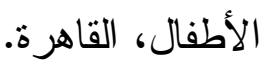

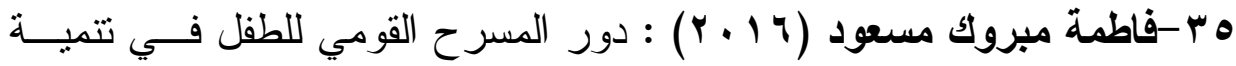

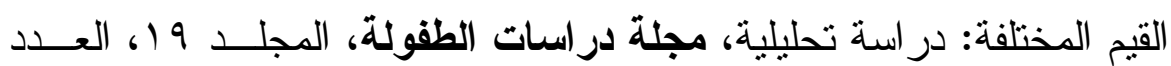

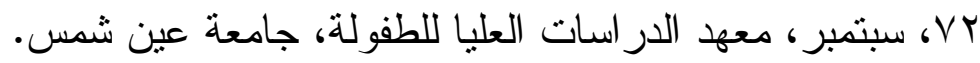

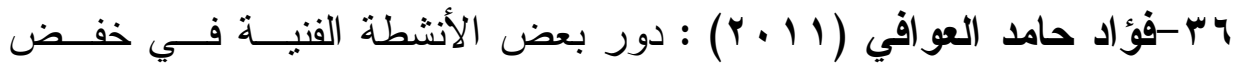

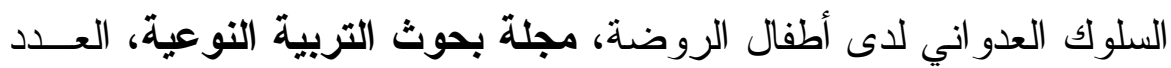
ب rا، كلية النزبية النوعية، جامعة المنصورة.

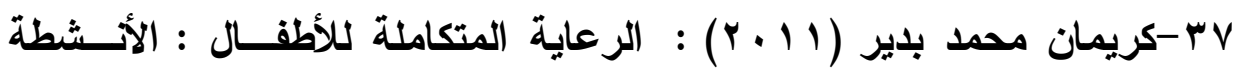

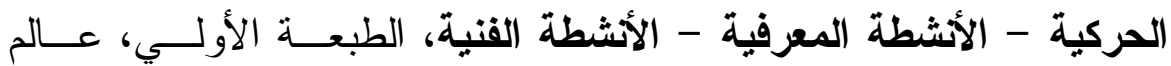
الكتاب للنشر و التنوزيع، القاهرة.

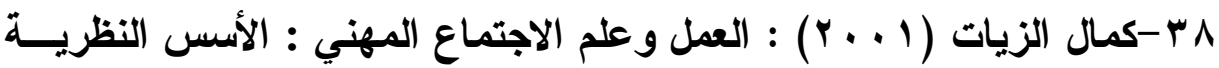
و المنهجية، دار غريب للطباعة و النشر، القاهرة.

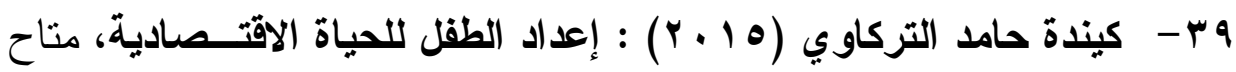
على شبكة الألوكة. https://www.alukah.net/social/0/96140/\#ixzz5Yr1hxbiS (Access On 5/12/2018)

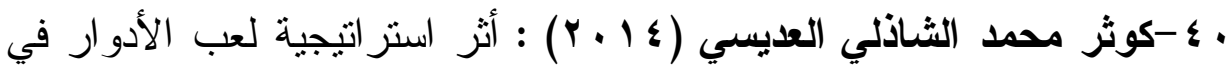

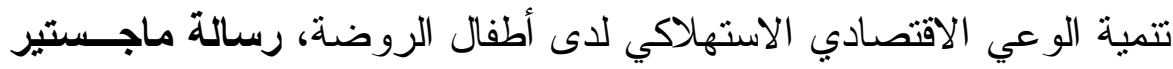
غير منشورة، كليه التزبية، جامعه جنوب الو ادي. 


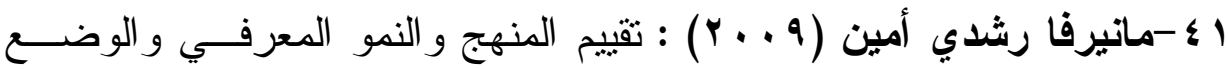

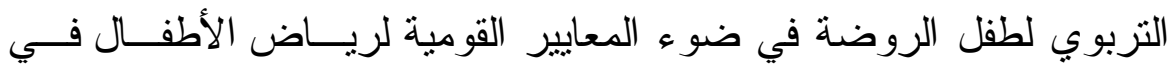

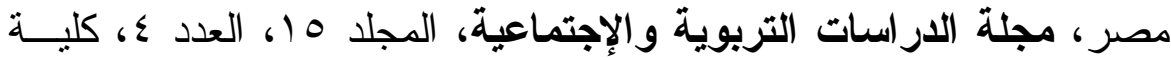

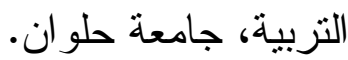

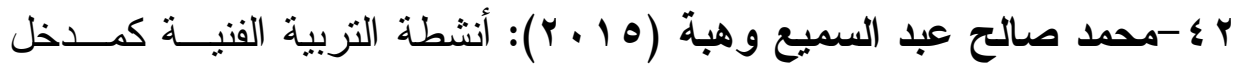

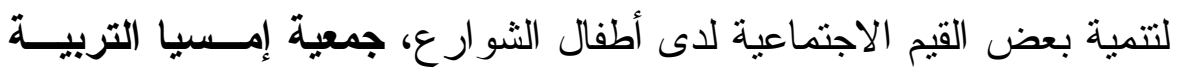
عن طريق الفن، العدد ع، القاهرة.

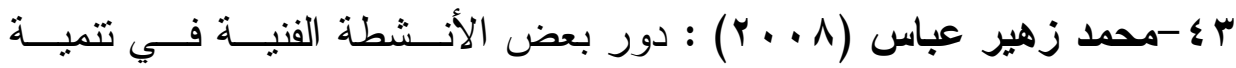

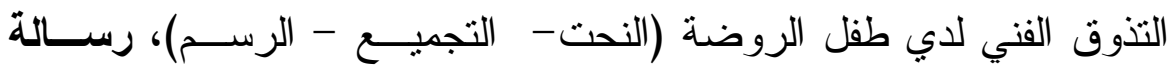
ماجنتير غير منشورة، كلية التربية، جامعة عين شمس.

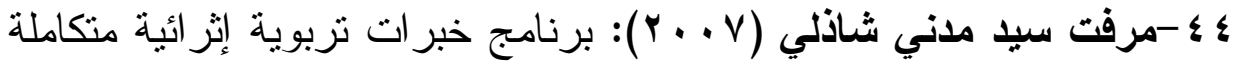

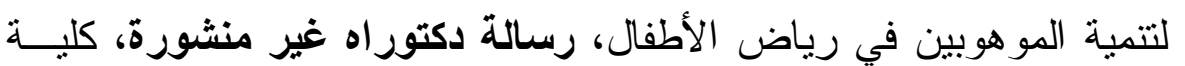
رياض الأطفال، جامعة القاهرة.

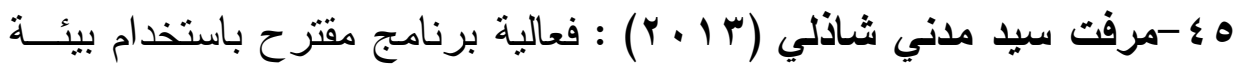

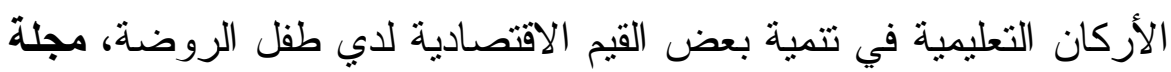

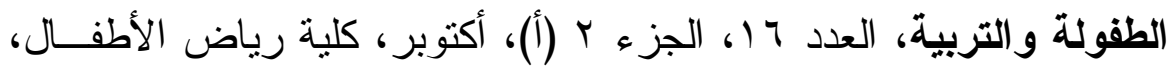

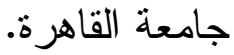

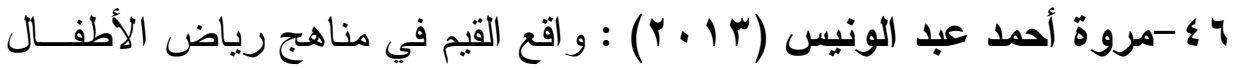

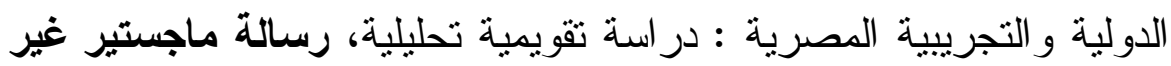
منشورة، معهد الدر اسات و البحوث التربوية، جامعة القاهرة. 


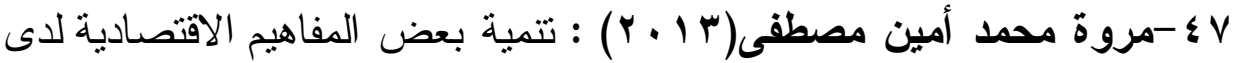

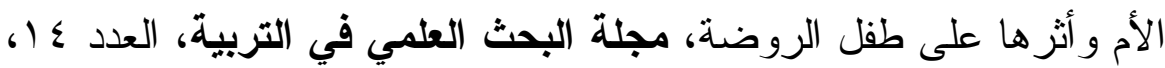
الجزء ا ، كلية البنات للآداب و العلوم و التربية، جامعة عين شمس.

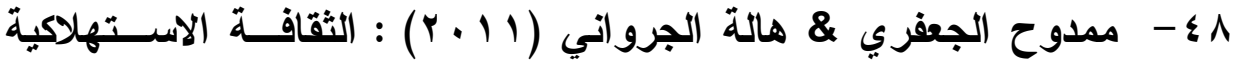

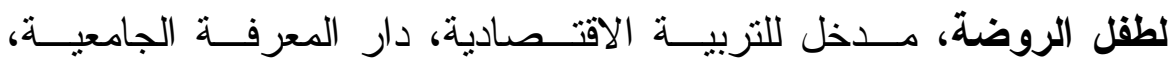
الإسكندرية.

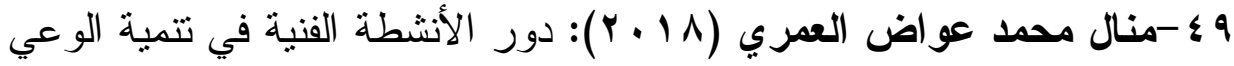
البيئي لاى طفل ما قبل المدرسة من وجهة نظر معلمات ريــاض الأطفــال

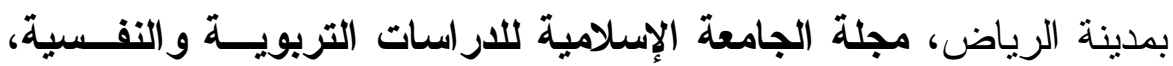

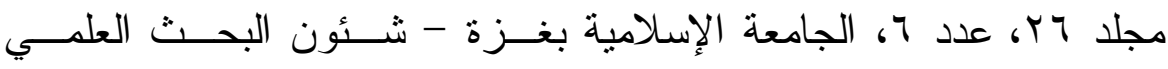

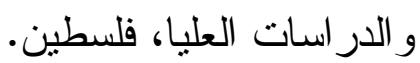

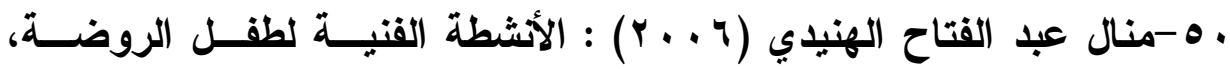
الطبعة الأولي، عالم الكتاب، القاهرة.

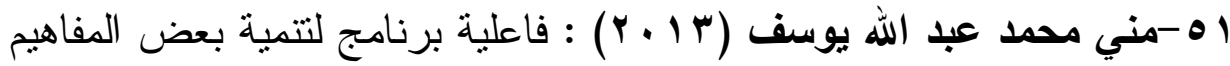

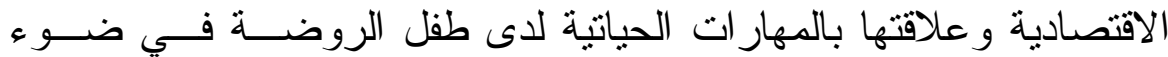
المعايير القومية لرياض الأطفال، رسالة دكتوراه غير منشورة، قسم العلوم التزبوية، كلية رياض الأطفال، جامعة القاهرة.

ror-مها جلال احمد علي (ع ا بr) : فاعلية برنامج قائم على أنشطة متكاملـــة

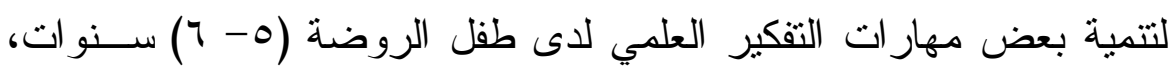

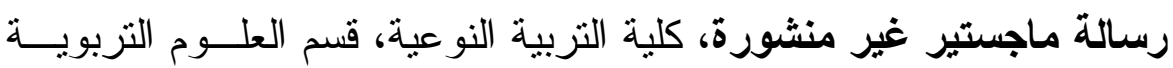
و النفسية، جامعة بنها. 


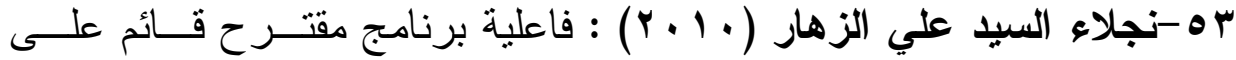

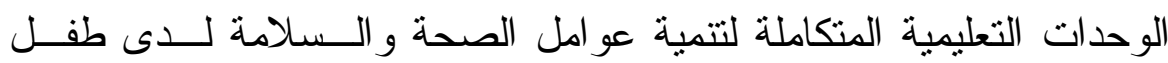

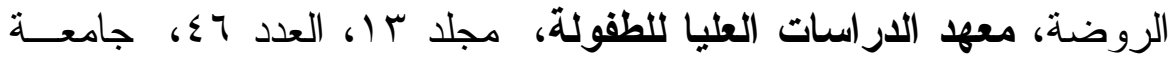

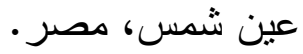

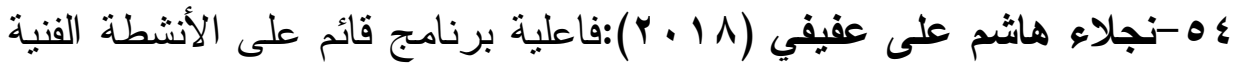
لتتمية الذكاء المكاني و التفكير الإبداعي و المهار ات الاجتماعية لدى أطفــال الروضة، رسالة دكتوراه غير منشورة، كلية التربية، جامعة حلوان.

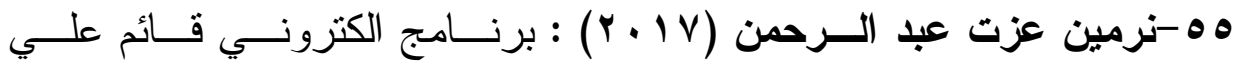

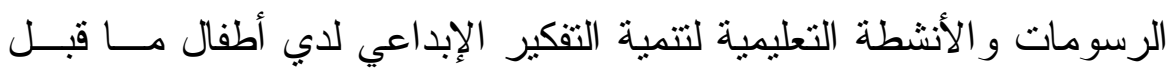

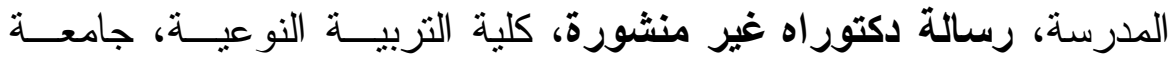

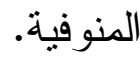

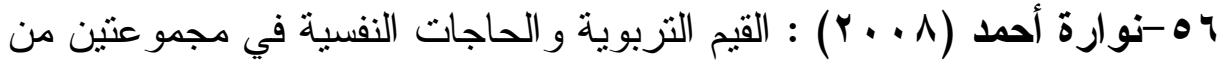
قصص الأطفال في لييا و أساليب تعزيز ها، رسالة ماجستير غير منشورة،

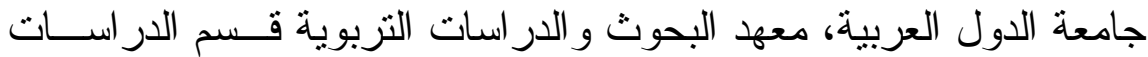

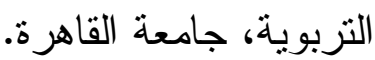

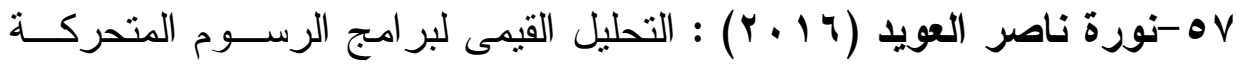

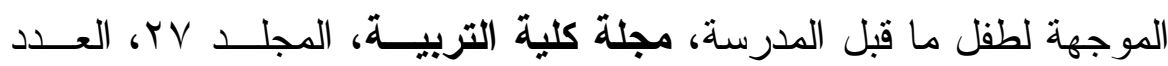
V • ا، يوليو، كلية التزبية، جامعة بنها.

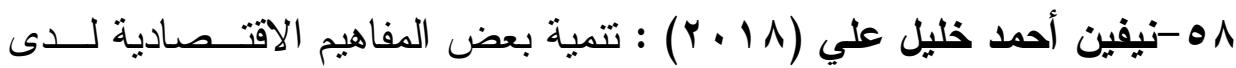

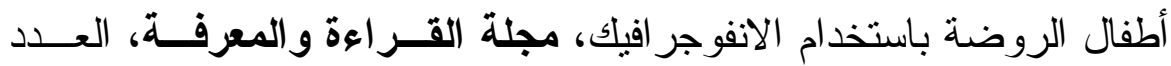

المجلد الخامس




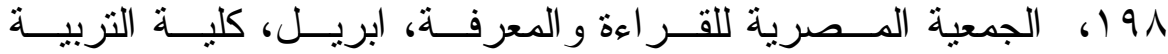
بالإسماعيلية، جامعة قناة السويس.

9 -وفاء حسين حسن مصطفى (r ( + r) : برنامج أنشطة مقترح لتتمية بعض

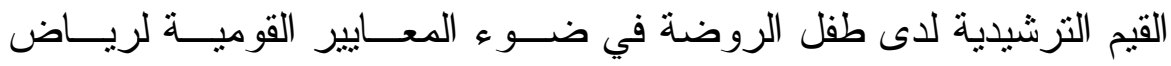

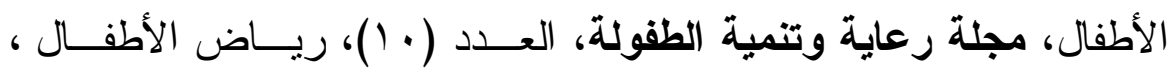

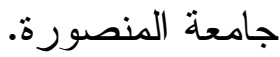

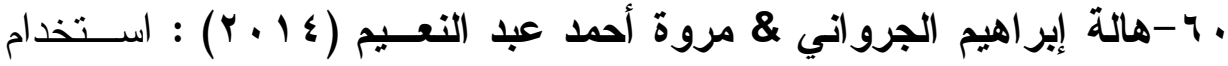
برنامج قائم على بعض الأنشطة الفنية في تتمية اتجاهات طفل الروضة نحو التهو

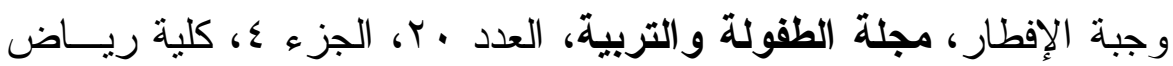

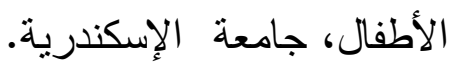

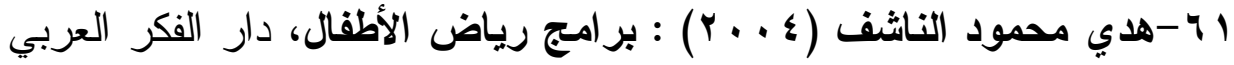
ل اللنشر و التوزيع، القاهرة.

r-هناء الحمود (11 + r) : مدي تأثثير الأطفال في تتمية القيم الاقتصادية لدي

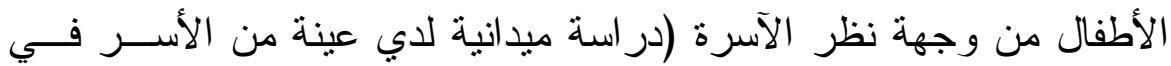

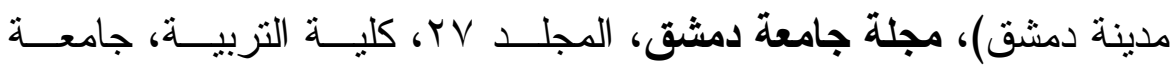
دمشق، سوريا.

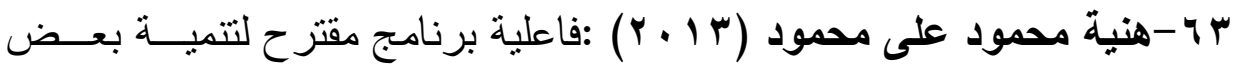
القيم الاقتصادية لدى طفل الروضة باستخدام التعلم النشط، رسالة دكتــوراه غير منشورة، كلية التربية بالو ادي الجديد، جامعة أسيوط. 


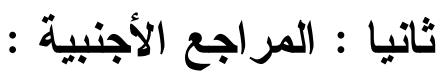

64-Ann Farrell, Sharon L Kagan, E. Kay M. Tisdall (2015) : The SAGE Handbook of Early Childhood Research, Libaray of congress, control number: 2015936048, P576, USA.

65-Bertling, J. (2005) : The Art of Empathy. A Mixed Methods Case Study of a Critical Place- Based Art Education Program. International Journal of Education \& the Arts. 16(13), 27-55.

66-Curtis, D.(2011) : Using the Arts to Raise Awareness and Communicate Environmental Information in the

Extension Context. Journal of Agricultural Education and Extension, 17(2), 181-194.

67- Furnham. Adrian. (2008): The Economic Socialization of Young People . Bloomsbury. Chinese New Year.

68-John R. Swinton, Thomas De Berry, Benjamin scafidi and Howard C. woodarda (2010): Doesin-service professional learning for nigh school economics teachers improve student achievement, Georgia College8 state University centen for economic Education, Milledgeville, Georgia, USA; bfreed- Hardeman University, Henderson, Tennessees, USA, vol. 18, No. 4, P395-405.

69-Koster, Joan B. (2012) : Growing Artists: Teaching the Arts to Young Children, 5th Ed. Belmont, Calif: Wadsworth Cengage Learning.

70-Mary Suiter and Bonnie T. Meszaros (2005) : Teaching about Saving and Investing in the Elementary and Middle School Grades, journal of Social Education, March.

r. المجلد الخامس


https://www.socialstudies.org/category/journal/socialeducation

71-Matthias Sutter, Claudia Zoller, Daniela GlätzleRützler (2018) : Economic behavior of children and adolescents - A first survey of experimental economics results, European Economic Review, Volume 111, January 2018, Pages 98-121, https://doi.org/10.1016/j.euroecorev.

72-Melissa Menzer (2015) ; THE ARTS IN EARLY CHILDHOOD: SOCIAL AND EMOTIONAL BENEFITS OF ARTS PARTICIPATION, A LITERATURE REVIEW AND GAP-ANALYSIS (2000-2015), In partnership with the NEA's Interagency Task Force on the Arts \& Human Development, usa.

73-Michael Beer and Russell A. Eisenstat (2011) : Higher Ambition: How Great Leaders Create Economic and Social Value, Aug 23, press.

74-UNESCO (1995) : Science for all Americans, New York, Oxford University Press.

http://www.unesco.org/new/ar/unesco/about-us/ (Access On $16 / 12 / 2018$ )

75-Walstad, William B.; Watts, Michael (2015) : Perspectives on Economics in the School Curriculum: Coursework, Content, and Research, Journal of Economic Education, v46 n3 p324-339. 